\title{
EVOLUÇÃO E RENTABILIDADE ECONÔMICA DO REFLORESTAMẸTO EM PEQUENOS E MÉDIOS IMÓVEIS RURAIS: OS CASOS DE MINAS GERAIS, SÃo PAULO E PARANÁ
}

\section{CASSIANA NAVARRETE NÉRIS}

Administradora de Empresas

Orientador: Prof. Dr. CARLOS JOSÉ CAETANO BACHA

Dissertação apresentada à Escola Superior de Agricultura "Luiz de Queiroz", Universidade de São Paulo, para obtenção do título de Mestre em Ciências, Área de Concentração: Economia Aplicada.

P I R A C I C A B A

Estado de São Paulo - Brasil

Fevereiro - 2001 


\title{
Dados Internacionais de Catalogação na Publicação (CIP) DIVISÃO DE BIBLIOTECA E DOCUMENTAÇÃO - Campus "Luiz de Queiroz"/USP
}

\author{
Néris, Cassiana Navarrete \\ Evolução e rentabilidade econômica do reflorestamento em pequenos e médios \\ imóveis rurais: os casos de Minas Gerais, São Paulo e Paraná / Cassiana Navarrete \\ Néris. - - Piracicaba, 2001. \\ $154 \mathrm{p}$. \\ Dissertação (mestrado) - - Escola Superior de Agricultura Luiz de Queiroz, 2001. \\ Bibliografia. \\ 1. Incentivo florestal 2. Propriedade rural 3. Reflorestamento 4. Renda agrícola 5. \\ Rentabilidade econômica I. Título
}

CDD 634.956

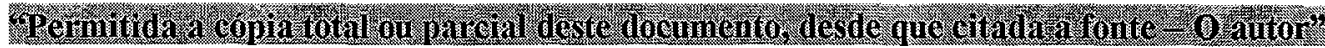

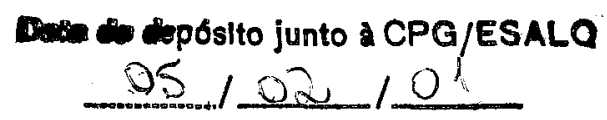




\section{AGRADECIMENTOS}

Ao professor Carlos José Caetano Bacha, pela orientação dedicada e competente, pelo profissionalismo e estímülo constante durante o desenvolvimento desta pesquisa.

Aos professores Alexandre Mendonça de Barros, Evaristo Marzabal Neves e Zilda Paes de Barros Mattos, pelas críticas e sugestões que contribuíram para o enriquecimento do trabalho.

Ao corpo docente do Departamento de Economia, Administração e Sociologia da ESALQ/USP, pelos importantes ensinamentos recebidos.

Aos colegas do curso de mestrado, especialmente aos amigos Alesandra B. Santos, Carla Regina F. Freire, Daniela Cristina Manhani, Ednéia Bezerra, Edson C. Bignotto, Fabio Mattos, Francisco Casimiro Filho, José de Arimatéia R. Machado, Viviane P. Mendonça, Zilmar José de Souza e Yáskara Max Raimundo.

Aos funcionários do LES/ESALQ, pela presteza e cooperação no decorrer do curso. Em especial a Cristiane, Helena, Ligiana, Luciene, Maielli, Márcia, Maria Helena e Pedro pelo convívio.

Ao Cnpq, pelo auxílio financeiro para a realização deste trabalho.

Por fim, a todos os profissionais envolvidos na realização deste trabalho, pelo fornecimento de dados e pela troca de informações. Em especial, a Ricardo Otto Leão Schmidt e Domício Lott pela contribuição recebida. 


\section{SUMÁRIO}

Página

LISTA DE FIGURAS..

LISTA DE QUADROS

vii

LISTA DE TABELAS.

viii

RESUMO.

$\mathrm{xi}$

SUMARY

xiii

1. INTRODUÇÃO.

1.1 Apresentação. 1

1.2 Objetivos. 7

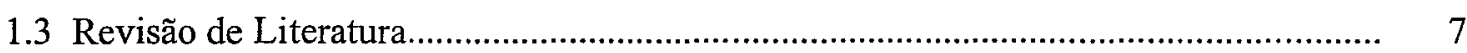

1.4 Organização do trabalho...................................................................................... 11

2. PROGRAMAS PÚBLICOS E PRIVADOS DE INCENTIVO AO REFLORESTAMENTO EM PEQUENOS E MÉDIOS IMÓVEIS RURAIS.

2.1 Programas Federais.

2.1.1 O Programa de Reflorestamento em Pequenos e Médios Imóveis Rurais no Estado de Minas Gerais.

2.1.2 O Programa de Reflorestamento em Pequenos e Médios Imóveis Rurais no Estado de São Paulo

2.1.3 O Programa de Reflorestamento em Pequenos e Médios Imóveis Rurais no Estado do Paraná.

2.2 Programas públicos e privados de fomento florestal no Estado de Minas Gerais.

2.2.1 Programas públicos estaduais em Minas Gerais

2.2.2 Programas privados de fomento florestal em Minas Gerais.

2.3 Programas da sociedade civil e privados de fomento florestal no Estado de São Paulo.

2.3.1 Programa de reposição florestal realizado pelas Associações de Recuperação Florestal em São Paulo.

2.3.2 Programa de reposição florestal realizado pela CESP em São Paulo..

2.3.3 Reflorestamento realizado pelo setor de papel e celulose em São Pulo.

2.4 Programas públicos $\mathrm{e} \cdot$ privados de fomento florestal no Estado do Paraná. 
2.4.1 Programas públicos estaduais no Paraná.................................................................. 39

2.4.2 Programas privados de fomento florestal no Paraná..................................................... 43

2.5 Comparação das políticas florestais implementadas em Minas Gerais, São Paulo e Paraná

3 A EVOLUÇÃO DA ÁREA REFLORESTADA EM MINAS GERAIS, SÃO PAULO E PARANÁ.

3.1 Evolução da área reflorestada anualmente em pequenos e médios imóveis rurais no Estado de Minas Gerais

3.2 Evolução da área reflorestada anualmente em pequenos e médios imóveis rurais no Estado de São Paulo.

3.3 Evolução da área reflorestada anualmente em pequenos e médios imóveis rurais no Estado do Paraná

3.4 Evolução do estoque de área reflorestada em Minas Gerais

3.5 Evolução do estoque de área reflorestada em São Paulo.

3.6 Evolução do estoque de área reflorestada no Paraná.

4 ANÁLISE DA RENTABILIDADE ECONÔMICA DOS REFLORESTAMENTOS EM PEQUENOS E MÉDIOS IMÓVEIS RURAIS..

4.1 Métodos de avaliação econômica de projetos

4.2 Projetos analisados e fonte dos dados

4.2.1 Considerações sobre os dados.

4.3 Estimativas dos indicadores de avaliação para os projetos selecionados - a análise determinista.

4.4 Análise de Sensibilidade.

4.5 Análise de Risco pela Simulação de Monte Carlo......................................................... 85

4.5.1 Metodologia da Simulação de Monte Carlo............................................................... 85

4.5.2 Estimativa dos indicadores de avaliação para os projetos selecionados - a análise de risco pela simulação de Monte Carlo.

5 CONCLUSÕES 92

REFERÊNCIAS BIBLIOGRÁFICAS. 96 APÊNDICE. 


\section{LISTA DE FIGURAS}

Página

1 Evolução da área ocupada com florestas plantadas segundo o tamanho da propriedade rural no Estado de Minas Gerais.......................................................

2 Evolução da área ocupada com florestas plantadas segundo o tamanho da propriedade rural no Estado de São Paulo

3 Evolução da área ocupada com florestas plantadas segundo o tamanho da propriedade rural no Estado do Paraná. 


\section{LISTA DE QUADROS}

Página

1 Programas privados de fomento florestal em parceria com o IEF - antes do PróFloresta..

2 Diferenças entre as políticas florestais implementadas em Minas Gerais, Paraná e São Paulo.

3 Diferenças entre os sistemas de plantio, manutenção, exploração e comercialização dos plantios oriundos dos reflorestamentos em pequenos e médios imóveis rurais nos Estados de Minas Gerais, Paraná e São Paulo.

4 Características dos projetos de reflorestamento analisados.

5 Valores do "Payback" econômico (em anos) segundo o projeto e a taxa de juros considerada. 


\section{LISTA DE TABELAS}

Página

1. Resultados dos programas federal e estaduais de estímulo ao reflorestamento nos pequenos e médios proprietários rurais no Estado de Minas Gerais situação em meados da década de 80

2. Resultados alcançados no período de 1989 a 1996 com o reflorestamento junto a pequenos e médios imóveis rurais com recursos do Fundo PróFloresta - Minas Gerais

3. Resultados alcançados no período de 1998 a 1999 com florestas de produção (plantio de eucalipto e pupunha) - Minas Gerais

4. Resultados alcançados no período de 1994 a 1999 com florestas de conservação (matas ciliares) - Minas Gerais

5. Resultados alcançados no período de 1989 a 1999 com florestas de proteção matas ciliares, proteção de nascentes, áreas degradadas e matas de topo (Minas Gerais)

6. Área reflorestada através do Programa Fazendeiro Florestal em Minas Gerais.

7. Atividades realizadas com $o$ fomento florestal nas Associações de Recuperação Florestal no Estado de São Paulo

8. Associações de Recuperação Florestal do Estado de São Paulo.

9. Área reflorestada (ha) com recursos próprios da CESP no Estado de São Paulo

10. Atividades realizadas com o fomento florestal pela CESP

11. Produção de mudas (unidade), por viveiro, pela CESP.

12. Resultados dos programas de fomento florestal do setor de papel e celulose no Estado de São Paulo

13. Destinação de mudas florestais (unidade) e área reflorestada (hectares) anualmente pelos programas oficiais de fomento florestal no Paraná (unidade).

14. Resultados dos programas de fomento florestal do setor de papel e celulose no Estado do Paraná

15. Área reflorestada (em ha) anualmente em Minas Gerais nos pequenos e médios imóveis rurais, segundo alguns segmentos 
16. Área reflorestada (em ha) anualmente em São Paulo nos pequenos e médios imóveis rurais segundo alguns segmentos.

17. Área reflorestada (em ha) anualmente no Paraná nos pequenos e médios imóveis rurais segundo alguns segmentos.

18. Área ocupada com florestas plantadas, segundo o tamanho da propriedade rural, no Estado de Minas Gerais (em ha).

19. Área ocupada com florestas plantadas, segundo a atividade econômica principal, no Estado de Minas Gerais (em ha)..

20. Área ocupada com florestas plantadas segundo o tamanho da propriedade rural, no Estado de São Paulo (em ha).

21. Área ocupada com florestas plantadas, segundo a atividade econômica principal, no Estado de São Paulo (em ha)..

22. Área ocupada com florestas plantadas, segundo o tamanho da propriedade rural, no Estado do Paraná (em ha)

23. Área ocupada com florestas plantadas segundo a atividade econômica principal no Estado do Paraná (em ha).

24. Valores Atuais (VA) dos projetos de reflorestamento, em $\mathrm{R} \$ / \mathrm{ha}$, considerando o custo de oportunidade do capital variando entre $6 \%$ e $20 \%$ ao ano, novembro de 1999 (sem incluir o custo da terra)..

25. Valores Atuais (VA) dos projetos de reflorestamento, em $\mathrm{R} \$ / \mathrm{ha}$, considerando o custo de oportunidade do capital variando entre $6 \%$ e $20 \%$ ao ano, novembro de 1999 (incluindo o custo da terra).

26. Relação Benefício/Custo (RBC) dos projetos de reflorestamento considerando o custo de oportunidade do capital variando entre $6 \%$ e $20 \%$ ao ano, novembro de 1999 (sem incluir o custo da terra).

27. Relação Benefício/Custo (RBC) dos projetos de reflorestamento considerando o custo de oportunidade do capital variando entre $6 \%$ e $20 \%$ ao ano, novembro de 1999 (incluindo o custo da terra).

28. Taxas Internas de Retorno (TIR) dos projetos de reflorestamento com eucalipto, em novembro de 1999 (sem incluir o custo da terra).

29. Taxas Internas de Retorno (TIR) dos projetos de reflorestamento com eucalipto, novembro de 1999 (incluindo o custo da terra).

30. Custos Totais Atualizados (CTA) dos projetos de reflorestamentos com eucalipto, em $\mathrm{R} \$ / \mathrm{ha}$, considerando o custo de oportunidade do capital variando entre $6 \%$ e $20 \%$ ao ano, novembro de 1999 (sem incluir o custo da terra).

31. Custos Totais Atualizados (CTA) dos projetos de reflorestamentos com eucalipto, em $\mathrm{R} \$ / \mathrm{ha}$, considerando o custo de oportunidade do capital 
variando entre $6 \%$ e $20 \%$ ao ano, novembro de 1999 (incluindo o custo da terra)

32. Valores Esperados da Terra (VET) dos projetos de reflorestamento considerando o custo de oportunidade do capital variando entre $6 \%$ e $20 \%$ ao ano, em R $\$$ ha, novembro de 1999

33. Valor Atual (VA), Taxa Interna de Retorno (TIR) e variação percentual em relação à análise determinista, para os projetos PR4*, SP4* e MG3* (novos cenários), novembro de 1999 .

34. Indicadores de rentabilidade considerando análise de risco para o plantio do eucalipto no Estado do Paraná (custo de oportunidade de 6\%)

35. Indicadores de rentabilidade considerando análise de risco para o plantio do eucalipto no Estado de Minas Gerais (custo de oportunidade de 6\%)

36. Indicadores de rentabilidade considerando análise de risco para o plantio do eucalipto no Estado de São Paulo (custo de oportunidade de 6\%).

37. Estimativa de alguns indicadores de rentabilidade considerando análise de risco para projetos na agricultura - sem incluir o custo da terra........................ 
EVOLUÇÃO E RENTABILIDADE ECONÔMICA DO REFLORESTAMENTO EM PEQUENOS E MÉDIOS IMÓVEIS RURAIS: O CASO DE MINAS GERAIS, SÃO PAULO E PARANÁ

\author{
Autora: CASSIANA NAVARRETE NÉRIS \\ Orientador: Prof. Dr. CARLOS JOSÉ CAETANO BACHA
}

\title{
RESUMO
}

O presente trabalho analisa a evolução do reflorestamento em pequenos e médios imóveis rurais, avaliando os impactos de programas públicos e privados sobre esses reflorestamentos. Considerou-se como casos em estudo os Estados de Minas Gerais, São Paulo e Paraná que possuem expressivas experiências em programas de estímulo a esse tipo de atividade. Para tanto, foram utilizados os dados disponíveis na literatura existente e entrevistas com técnicos da área.

Inicialmente, analisa-se os programas públicos e privados de incentivo ao reflorestamento em pequenos e médios imóveis rurais que ocorreram e ainda ocorrem nos Estados em questão, ressaltando suas diferenças e resultados.

Conhecidos os programas implantados, procura-se averiguar a importância dos diferentes segmentos na promoção do fomento florestal nos três Estados. Conclui-se que em Minas Gerais a iniciativa privada e o Governo Estadual são bastante atuantes no fomento florestal. No Estado do Paraná, existe grande concentração no Poder Estadual, através do Instituto Ambiental do Paraná, das atividades voltadas ao fomento do reflorestamento em pequenos e médios imóveis rurais. Em São Paulo é a sociedade civil (através das Associações de Reposição Florestal) que promove o reflorestamento junto a pequenos e médios imóveis rurais. Além disso, em São Paulo e no Paraná as empresas de papel e celulose estimulam o plantio de florestas em pequenos e médios imóveis rurais, enquanto em Minas Gerais são as empresas siderúrgicas que se destacam no fomento privado. 
Diante desse cenário, é analisada a evolução do reflorestamento nos pequenos e médios imóveis rurais. Constata-se que, entre os anos de 1970 e 1995, existe o crescimento do estoque de área reflorestada nas pequenas e médias propriedades rurais nos Estados de Minas Gerais e Paraná e o decréscimo no Estado de São Paulo. Isto demonstra que a sistemática adotada em Minas Gerais e no Paraná para estímulo do reflorestamento em pequenas e médias propriedades rurais têm tido maior eficácia do que a sistemática adotada em São Paulo.

Em seguida, é realizada a análise de rentabilidade econômica de projetos de reflorestamento com eucalipto sob condições representativas dos cenários dos Estados do Paraná, São Paulo e Minas Gerais. Conclui-se que os projetos são economicamente viáveis à taxa de juros de até $7 \%$ ao ano no Paraná e de até $10 \%$ ao ano em São Paulo. Os únicos projetos considerados viáveis até a taxa de juros de $20 \%$ ao ano ocorrem em Minas Gerais.

A doação de mudas nos programas de fomento florestal é responsável pelo aumento de 8,3\% na rentabilidade dos projetos no Estado do Paraná e de 6,8\% no Estado de São Paulo. No Estado de Minas Gerais, a doação de mudas e insumos é responsável pelo aumento de $43,88 \%$ ou de $52,19 \%$ na rentabilidade dos projetos segundo o esquema de compra da madeira estabelecido entre o fazendeiro e a empresa fomentadora.

O trabalho termina por sugerir que os programas de fomento florestal não devem apenas basear-se na doação de mudas, mas também garantir maior integração entre os produtores e os compradores de madeira. Também sugere novas linhas de pesquisa que podem gerar subsídios para a redefinição ou elaboração de futuros programas de incentivo ao reflorestamento em pequenos e médios imóveis rurais. 
xiii

THE EVOLUTION AND ECONOMICS RESULTS OF REFORESTATION IN SMALL AND MEDIUM FARMS: THE STUDY CASES OF MINAS GERAIS, SÃO PAULO AND PARANÁ STATES

\author{
Author: CASSIANA NAVARRETE NÉRIS \\ Adviser: Prof. Dr. CARLOS JOSÉ CAETANO BACHA
}

\title{
SUMMARY
}

The purpose of this dissertation is to analyze the evolution of reforestation in small and medium farms, evaluating the impacts of public and private programs over these reforestation. For that, the experiences of Minas Gerais, São Paulo and Paraná states were taken for analyzing because those states have had great success in that kind of program. This study makes use of information that are available in specialized biography as well as those obtained from interviews made with people who work in that activity.

This dissertation followed three stages. First, public and private programs drawn to stimulate the reforestation in small and medium farms, in the past and currently, were analyzed. In that analysis, outcomes and differences among those programs are pointed out.

In the state of Minas Gerais, private sector and State Government have actively stimulated the forest development. In the state of Paraná, a huge concentration of decisions and actions are under state administration, especially through the Paraná's Environment Institute. The latter organizes activities driven to stimulate the reforestation in small and medium farms. Otherwise, in the state of São Paulo, civil organizations - especially the Forest Restoration Associations - have been fostering the reforestation in small and medium farms.

On the one hand, pulp and paper companies are the most important enterprises to encourage the reforestation in small and medium farms in São Paulo and Paraná 
states. On the other hand, in the state of Minas Gerais that job has been developed by steel makers.

The second stage of this dissertation was to analyze the evolution of reforested area stocks in small and medium farms. In Paraná and Minas Gerais states there were increases in that variable value between 1970 and 1995, but in the state of São Paulo it has been decreased. That outcome proves that the policies adopted by Minas Gerais and Paraná states had more efficacy than the one implemented by the state of São Paulo in order to foster the reforestation in small and medium farms.

The third stage of this dissertation was to make an economic evaluation of the impacts of those state programs over the profits made in reforestation projects. For that, representative cases of eucalyptus reforestation in Paraná, São Paulo and Minas Gerais states were taken into account.

It was concluded that reforestation projects were economically viable up to $7 \%$ APR (annual percentage interest rate) in the sate of Paraná and until 10\% APR in the state of São Paulo. In the sate of Minas Gerais, reforestation projects using eucalyptus were viable until $20 \%$ APR.

The grants of seedling in forest development program can rise $8.3 \%$ and $6.8 \%$ the profits of reforestation projects in Paraná and São Paulo states, respectively. Otherwise, the grants of seedling and agricultural inputs answered by $43.88 \%$ or $52.19 \%$ of increase in reforestation profit in the state of Minas Gerais. The latter depends on the scheme established between farmers and enterprises in relation to the wood marketing.

Finally, this dissertation suggests, on the one hand, that reforestation development programs need not only to grant seedlings, but also to create larger relationship between sellers and buyers of wood. On the other hand, this dissertation suggests news subjects that can be analyzed in order to generate new information, which can improve reforestation development programs. 


\section{INTRODUÇÃo}

\subsection{Apresentação}

Este trabalho analisa a evolução do reflorestamento em pequenos e médios imóveis rurais, avaliando os impactos de programas públicos e privados sobre esses reflorestamentos. Para tanto, são tomados os casos do Estados de Minas Gerais, São Paulo e Paraná que possuem expressivas experiências em programas de estímulo a esse tipo de atividade.

Não há consenso na literatura sobre o que são pequenos, médios e grandes imóveis rurais. Segundo o Banco Central do Brasil (1995), o Sistema Nacional de Crédito Rural faz uma classificação dos produtores rurais de acordo com a renda bruta anual alcançada. Dessa maneira, o beneficiário classifica-se como miniprodutor quando não contar com renda agropecuária bruta anual superior a R $\$ 7.500,00$ (equivalente a 49,7 salários mínimos ${ }^{1}$ ao ano). O pequeno produtor é aquele que conta com uma renda agropecuária bruta anual superior a $\mathbf{R} \$ 7.500,00$ e inferior a $\mathrm{R} \$ 22.000,00$ (isto é, renda bruta anual entre 49,7 e 145,7 salários mínimos ao ano). Não existem as classificações médio e grande produtores, estes são enquadrados na categoria de demais produtores, onde a renda agropecuária bruta anual é superior a $R \$ 22.000,00$ (ou superior a 145,7 salários mínimos no ano).

Por outro lado, o Censo Agropecuário faz uma classificação dos produtores rurais de acordo com a área da propriedade. Assim, são enquadrados como pequenas propriedades aquelas com até 50 hectares. As médias propriedades são aquelas de 50 a

\footnotetext{
${ }^{1} \mathrm{O}$ salário mínimo mensal atual é de $\mathrm{R} \$ 151,00$.
} 
500 hectares e as grandes propriedades são aquelas com 500 hectares ou mais. No presente trabalho utilizou-se esta classificação do Censo Agropecuário pois, as informações sobre as propriedades que realizam reflorestamento são disponíveis por estratos de área.

As pequenas propriedades rurais sofrem com o baixo nível de renda de seus agentes e a falta de conservação do solo, que são hoje alguns dos mais graves problemas a elas relacionados. $\mathrm{O}$ que se discute é como exterminar estes problemas e oferecer aos residentes no meio rural melhores condições de vida.

Segundo Angelo (1987, p. 38), o baixo nível de renda das pequenas propriedades rurais tem sido explicado como resultante da união entre a pequena extensão de terra $\mathrm{e}$ a baixa produtividade alcançada pelas pequenas propriedades devido ao emprego da tecnologia tradicional que, na maioria das vezes, gera uma renda familiar que equivale a menos de um salário mínimo. Geralmente, o que ocorre é o subemprego da mão-de-obra familiar. Isso se agrava ainda mais quando se sabe que o grande contingente de força de trabalho rural localiza-se nas pequenas e médias propriedades. Segundo o Censo Agropecuário, no período de 1995/96, os intervalos de áreas que mais absorveram mãode-obra foram os de menos de 10 ha e os de 10 a menos de 100 ha, com respectivamente, $40,7 \%$ e $39,9 \%$ do pessoal ocupado total. Em contrapartida, os estabelecimentos com mais de 1000 ha absorveram apenas $4,2 \%$ do pessoal ocupado.

No que diz respeito à falta de conservação adequada do solo, já se observa em algumas regiões a queda de produtividade de algumas culturas destinadas ao abastecimento interno causada pela falta de conservação do solo. As pequenas propriedades, que são em parte as responsáveis pela produção destas culturas, devido ao uso intensivo da terra sem a sua devida conservação, são as mais prejudicadas.

Como resposta aos problemas acima comentados, a silvicultura vem sendo apontada como uma alternativa para os pequenos e médios produtores rurais, em especial para ocupar terras ociosas e sem grandes alternativas de uso. De maneira em geral, os beneficios trazidos com a conservação de florestas já existentes e a formação de novos plantios em pequenas e médias propriedades rurais atendem a uma série de 
interesses ecológicos, sociais e econômicos. Alguns Estados têm implementado programas de incentivo ao reflorestamento que visam beneficiar o pequeno e médio produtor rural. Esses programas são iniciativas dos governos estaduais ou sociedades civis que, aliados às atividades de algumas empresas privadas, promovem a silvicultura em pequenas e médias propriedades.

O reflorestamento em pequenos e médios imóveis rurais tem grande importância como fonte de renda ao produtor pois, em geral, a floresta produz a matéria-prima para construções rurais e residenciais, o carvão, cercas e postes, resinas, além da madeira necessária para a confecção de ferramentas utilizadas no campo. Dessa maneira, recursos que seriam dispendidos na compra da madeira passam a ser utilizados em outras atividades. Além disso, existe ainda a possibilidade de comercialização de excedentes da matéria-prima florestal, o que representa ganhos adicionais ao produtor rural (Angelo, 1987).

Os pequenos produtores têm, de modo em geral, mais dificuldades em conseguir beneficios de programas e políticas governamentais. No passado, o governo federal atuou junto àqueles que possuiam maior vantagem comparativa derivada de seu porte econômico e, dessa maneira, os programas de incentivos fiscais ao reflorestamento beneficiaram os grandes imóveis rurais. Todavia, existem alguns programas de incentivo ao reflorestamento voltado aos pequenos e médios imóveis rurais, programas estes tanto de caráter público quanto privado. Dentre os programas públicos tem-se aqueles que são de abrangência federal e aqueles de abrangência estadual.

Os dois programas federais de incentivo ao reflorestamento voltado ao pequeno e médio produtor foram o REPEMIR - "Programa de Reflorestamento em Pequenos e Médios Imóveis Rurais" e o "Projeto Algaroba". O primeiro tinha por objetivo aumentar a oferta de lenha e carvão vegetal e propiciar a comercialização, pelo produtor rural, do excedente desses produtos, bem como, fornecer ao pequeno e médio proprietário rural madeira para utilização em sua propriedade. O REPEMIR foi implantado pelo governo federal através de convênios estabelecidos entre o então Instituto Brasileiro de Desenvolvimento Florestal (IBDF) e órgãos estaduais. O "Projeto Algaroba" foi 
realizado no período de 1985 e 1988 e foi fundamentado na produção e distribuição de mudas de algarobeiras, prestação de assistência técnica e apoio financeiro aos produtores rurais da área de atuação da Superintendência do Desenvolvimento do Nordeste, a SUDENE (Bacha, 1995).

De acordo com Lima (1985, p. 28), a algarobeira é uma espécie adequada ao reflorestamento no Nordeste devido a sua adaptação às condições de solo e clima dessa região. Assim, o "Projeto Algaroba" buscou evitar processos de desertificação do solo além de se constituir em um fator de fixação do homem no meio rural.

Minas Gerais, São Paulo e Paraná são os Estados que se destacam na implantação de programas estaduais de estímulo ao reflorestamento em pequenos e médios imóveis rurais.

O Estado de Minas Gerais tem uma ampla experiência na implantação de programas de incentivo ao reflorestamento. Dentre os programas executados destacamse a "Campanha Integrada de Reflorestamento", o "Programa de Desenvolvimento Integrado da Zona da Mata" (PRODEMATA), o "Programa Estadual de Promoção de Pequenos Produtores Rurais" (MGII), o "Programa de Desenvolvimento Rural Integrado do Noroeste" (PLANOROESTE II), o "Programa Estadual de Conservação e Produção Florestal" (PRÓ-FLORESTA) e o "Programa de Recuperação de Matas Ciliares e Áreas Degradadas".

Também são expressivos em Minas Gerais os reflorestamentos realizados com incentivos de empresas. As pioneiras no incentivo ao reflorestamento junto a pequenos e médios produtores rurais foram a Companhia Vale do Rio Doce (CVRD), a Celulose Nipo-Brasileira (CENIBRA S/A), a Companhia Agrícola e Florestal Santa Bárbara (CAF Ltda) e as Indústrias Matarazzo de Papéis S.A.. A elas se uniram 39 empresas, cujos reflorestamentos compõem o "Programa Fazendeiro Florestal" que consiste no reflorestamento de áreas pequenas e médias adequadas à agropecuária, mediante a cooperação mútua entre proprietários rurais e a empresa consumidora de matéria-prima florestal. 
Da mesma forma, no Estado do Paraná o governo estadual desenvolveu alguns programas que integraram o produtor rural à atividade de reflorestamento. Na década de 80 os programas implantados foram o "Programa de Desenvolvimento do Oeste do Paraná" (PRODOPAR), o "Programa Especial de Controle de Erosão dos Solos do Noroeste do Paraná (PRONOROESTE) e o "Programa de Apoio Integrado ao Pequeno Produtor Rural" (PRÓ-RURAL). A partir da segunda metade da década de 80, o governo do Estado lançou, também, o "Programa de Manejo Integrado do Solo e da Água" (PMISA), o "Programa Paraná-Rural" e o "Programa de Desenvolvimento Florestal Integrado" (PDFI).

Em 1997, o governo do Estado do Paraná criou dois novos programas de fomento ao plantio de florestas: o "Programa Estadual de Desenvolvimento Florestal" (PRODEFLOR) e o "Programa Florestas Municipais".

São Paulo, de maneira diferente dos Estados citados acima, conta com programas em que, basicamente, quem promove o reflorestamento em pequenos e médios imóveis rurais são as empresas privadas ou sociedades civis sem fins lucrativos. Estas são as Associações de Recuperação Florestal. "Estas associações são entidades civis, sem fins lucrativos, que congregam pessoas físicas e jurídicas consumidoras de matéria-prima com um consumo de até 12000 estéreos de lenha por ano e pessoas interessadas na conservação dos recursos florestais" (Andrews, 1991, p. 58).

Além do Programa de Reposição Florestal realizado pelas associações existe também o programa de reposição florestal realizado pela Companhia Energética de São Paulo (CESP), que consiste em recompor as matas nativas ao redor de seus reservatórios e áreas de influência. Isto, de maneira em geral, é feito mediante a reposição direta por parte da empresa ou por um programa de fomento florestal.

Observe que no Estado de São Paulo não é o poder público que recolhe o valor monetário correspondente à reposição florestal dos pequenos e médios consumidores de matéria-prima. Esta função foi redirecionada às Associações de Recuperação Florestal que devem implantar o equivalente ao material florestal consumido. 
Segundo Bacha (1998), Minas Gerais possui uma política própria de reposição florestal que foi definida na Resolução no 2 de 21/12/92. Esta resolução atribui às pessoas físicas e jurídicas que consomem, utilizam, industrializam, comercializam e beneficiam produtos da flora (exceto os que não eliminam as espécies) a promoção direta da reposição florestal, a participação em empreendimentos florestais de terceiros ou em sistemas cooperativos. Os pequenos e médios consumidores de produtos florestais têm a opção de recolher ao IEF, na conta recursos especiais a aplicar, o valor correspondente à reposição florestal. Esta mesma opção existe no Paraná, onde a taxa de reposição florestal é paga ao Instituto Ambiental do Paraná (IAP) que usa esses recursos para complementar o seu orçamento (de onde são pagas as despesas com produção de mudas distribuídas nos programas estaduais).

Constata-se que existem diferenças entre os três Estados analisados quanto às sistemáticas de incentivos ao reflorestamento em pequenos e médios imóveis rurais. Dessa maneira, torna-se importante uma discussão aprofundada sobre os programas de incentivo a esses reflorestamentos nesses Estados.

Por outro lado, sob a ótica do produtor rural, é necessário avaliar se é interessante para ele participar do fomento florestal. Pasicola et al. (1997) atribuem à renda obtida com a venda dos produtos florestais um forte incentivo ao reflorestamento nas propriedades. Inúmeras são as vantagens atribuídas ao reflorestamento em pequenos e médios imóveis rurais (como descrito acima) e diversos são os programas executados para incentivar este tipo de atividade. Entretanto, é necessária a análise da rentabilidade econômica de projetos de reflorestamento realizados nas pequenas propriedades em Minas Gerais, São Paulo e Paraná e como ela é afetada pelos programas realizados nesses Estados. Esta análise serve para redefinir futuros programas de incentivo ao reflorestamento em pequenos e médios imóveis rurais. 


\subsection{Objetivos}

O objetivo geral do trabalho é analisar a evolução dos reflorestamentos em pequenos e médios imóveis rurais nos Estados de Minas Gerais, São Paulo e Paraná, avaliando os impactos de programas públicos e privados sobre esses reflorestamentos. $O$ período de análise compreende as décadas de 70, 80 e 90, para as quais possuímos dados e onde têm sido realizados esses programas.

Os objetivos específicos são:

- analisar, através de método descritivo, os programas públicos e privados de incentivo ao reflorestamento em pequenos e médios imóveis rurais;

- avaliar, por meio de análise tabular e gráfica, a evolução do reflorestamento em pequenos e médios imóveis rurais nos Estados de Minas Gerais, São Paulo e Paraná, averiguando como os programas públicos e privados contribuíram para determinar o ritmo de reflorestamento e o estoque de florestas plantadas nos Estados em análise; e,

- calcular os principais indicadores de rentabilidade de projetos de investimentos em reflorestamentos com eucalipto nos Estados em questão, para situações deterministas e em condições de risco, verificando como os programas estaduais afetam essa rentabilidade.

\subsection{Revisão de Literatura}

Há diversos trabalhos na literatura que analisaram o Programa de Incentivos Fiscais ao Florestamento e Reflorestamento (PIFFR). Entre esses trabalhos, destacam-se Ariente (1983) e Bacha (1995).

O PIFFR foi executado de 1966 a 1988 e beneficiou, basicamente, grandes empresas na administração de reflorestamentos homogêneos. A sistemática do PIFFR era fundamentada na possibilidade de abatimento no Imposto de Renda devido dos valores gastos na implantação de maciços florestais homogêneos. Inicialmente, para as pessoas fisicas era permitido abaterem até o limite máximo de $50 \%$ de sua renda bruta 
tributável. As pessoas jurídicas podiam abater até $50 \%$ do Imposto de Renda devido. Ao longo do tempo, algumas alterações foram realizadas buscando corrigir deficiências na sistemática do programa ${ }^{2}$. Em geral, foram modificados os limites de dedução do imposto de renda das pessoas físicas e jurídicas, as formas de organização das pessoas jurídicas responsáveis pelos empreendimentos florestais e os períodos de vigência do incentivo.

Bacha (1995) analisou o custo-beneficio dos programas federais de incentivo ao reflorestamento, ressaltando as diferenças de custos por hectare incentivado em cada programa e avaliando a distribuição dos incentivos fiscais entre os agentes. $O$ resultado constatado foi que os beneficios sociais advindos do incentivo fiscal ao reflorestamento foram muitos pequenos em relação aos custos sociais incorridos nos programas em questão. $\mathrm{O}$ autor também descreveu as peculiaridades do Programa de Incentivos Fiscais ao Florestamento e Reflorestamento e analisou o REPEMIR e sua forma de operacionalização entre os Estados brasileiros. No entanto, teve poucos dados para proceder a uma análise estadual mais aprofundada.

O número de trabalhos que analisam o REPEMIR é consideravelmente pequeno quando em comparação àqueles que analisam o PIFFR (Programa de Incentivo ao Florestamento e Reflorestamento). Dentre eles destacam-se Yamazoe et al. (1988) e Bergamasco \& Bergamasco (1988).

Yamazoe et al. (1988) aplicaram um laudo de avaliação aos produtores paulistas que participaram do REPEMIR. O objetivo básico consistiu no levantamento dendométrico dos reflorestamentos e apontamento das falhas e dificuldades encontradas no programa. As principais deficiências foram a dificuldade de obtenção de mudas de boa qualidade e em época apropriada e a falta de orientação técnica aos produtores rurais.

Bergamasco \& Bergamasco (1988) utilizaram a pesquisa de campo de Yamazoe et al. (1988) para analisar aspectos sociais, econômicos e técnicos do REPEMIR.

\footnotetext{
${ }^{2}$ Para maiores detalhes ver Bacha (1995) e Ariente (1983).
} 
Verificaram que a produtividade alcançada nos plantios foi muito baixa, o tamanho máximo imposto para as propriedades beneficiadas não foi obedecido e em algumas regiões as espécies plantadas não eram recomendadas tecnicamente. Bergamasco \& Bergamasco (1998) concluíram que os projetos de reflorestamento implantados no Estado através deste programa só foram viáveis devido aos incentivos oferecidos pelo REPEMIR.

Alguns trabalhos analisaram os programas públicos de Minas Gerais para incentivo ao reflorestamento. Dentre eles, tem-se Rezende (1975) que, por meio de entrevista direta com os agricultores participantes do PRODEMATA, procurou comparar propriedades com reflorestamento com aquelas sem essa atividade. $\mathrm{O}$ autor concluiu que, quanto ao uso da terra, as propriedades com reflorestamento competiam diretamente com a pecuária. Além disso, concluiu que aquelas propriedades que possuíam o reflorestamento exibiam produtividade média dos fatores e rendimento dos cultivos explorados maiores do que as propriedades onde não existia a exploração florestal; o que possibilitava o aumento da renda do produtor.

Neves (1979) avaliou, do ponto de vista sócio-econômico, um programa de reflorestamento implantado na região de Carbonita, Vale do Jequitinhonha de Minas Gerais. Utilizando os métodos do Valor Presente Líquido e da Taxa Interna de Retorno, o autor averiguou ser o programa economicamente viável. Além disso, estimou que o programa proporcionou 1.629 empregos na área rural.

Assis et al. (1986) avaliaram o que foi o PRODEMATA e seus resultados no que diz respeito aos fatores técnicos, sociais e econômicos. Neste trabalho foi observado que, apesar da adoção de técnicas simples na implantação e manutenção dos reflorestamentos, os plantios foram bem conduzidos. Verificou-se que, considerando apenas as atividades de implantação, manutenção e exploração, eram as menores propriedades (com área de 0 a 10 hectares) que possuíam maior capacidade de geração de empregos. Os autores averiguaram o predomínio de cortes visando a madeira, principalmente, para uso de terceiros (para atender os setores de papel/celulose, siderúrgico e da construção civil). 
Carvalho (1996) fez uma análise do desmatamento sofrido em Minas Gerais e a evolução do processo de gestão florestal no Estado. O autor utilizou no trabalho a análise tabular e descreveu a reorganização promovida no setor florestal em Minas Gerais. Esta última foi implementada na tentativa de se obter maior eficácia na administração dos recursos florestais. Entre as principais mudanças, destacam-se: a adequação da estrutura administrativa do Instituto Estadual de Florestas, a repressão ao desmatamento ilegal e o monitoramento da cobertura florestal, a indução ao manejo sustentado, o aprimoramento da taxa florestal, a indução à reposição florestal e o incentivo ao fomento e extensão florestal através, principalmente, do engajamento de produtores rurais.

Analisando as politicas florestais do Paraná destaca-se o trabalho de Bacha (1996). O autor analisou o desmatamento ocorrido no Estado do Paraná, discutindo os aspectos que contribuiram para a devastação florestal no Estado, dentre estes a ineficiência da política florestal. Este autor também discutiu as soluções propostas pelo Estado, principalmente, as estratégias implementadas que unem mecanismos para controle do desmatamento e da reposição florestal com incentivos econômicos para a preservação das florestas nativas e a realização de empreendimentos florestais.

Bacha (1998) descreveu as experiências de politicas florestais de Minas Gerais, Rio de Janeiro, São Paulo e Paraná. O enfoque principal do trabalho foram os instrumentos de política econômica utilizados pelos Estados no tratamento de suas questões florestais.

Analisando os programas estaduais de estímulo ao reflorestamento em pequenos e médios imóveis rurais no Estado de São Paulo destacam-se Andrews (1991) e Fernandes (1985).

Andrews (1991) avaliou o desempenho das Associações de Recuperação Florestal do Estado de São Paulo. Para tanto, realizou pesquisa direta junto aos consumidores de produtos florestais e agricultores envolvidos nos programas de fomento das associações. A principal conclusão obtida foi que o fomento florestal desenvolvido pelas Associações de Recuperação Florestal no Estado de São Paulo não atendia 
plenamente as expectativas dos consumidores de produtos florestais (panificadoras, olarias, serrarias entre outros). Isto porque as associações não garantiam que a taxa de reposição florestal paga pelos consumidores de produtos florestais retornasse a eles sob a forma de produto florestal (principalmente, lenha).

Fernandes (1985) descreveu as atividades da Companhia Energética de São Paulo e os problemas causados ao meio ambiente e, em específico, à cobertura florestal devido à execução dessas atividades (principalmente da formação de lagos artificiais). $O$ autor relatou a conscientização da empresa quanto aos impactos ambientais que causa $\mathrm{e}$ sua adequação para amenizá-los. $O$ autor também expôs a sistemática adotada pela empresa no Plano de Fomento Florestal mas, pouco se sabia, na época em que o trabalho foi realizado, sobre os resultados alcançados em termos de áreas de matas ciliares reflorestadas.

Da exposição acima, constata-se que a maioria dos trabalhos sobre a questão florestal, em nível estadual, limita-se a discussão parcial das politicas florestais implantadas e suas implicações. Poucos são os trabalhos que analisam o reflorestamento em pequenas e médias propriedades rurais sob a ótica do produtor rural, avaliando-o privadamente. Dessa forma, há carência de uma avaliação comparativa das políticas estaduais de incentivo ao reflorestamento em pequenos e médios imóveis rurais e seus impactos sobre a rentabilidade desse tipo de atividade. $O$ presente trabalho procura fazer esse estudo.

\subsection{Organização do trabalho}

O presente trabalho é composto por 5 capitulos, incluindo esta Introdução. No capítulo 2 são discutidos os programas públicos e privados de incentivo ao reflorestamento em pequenos e médios imóveis rurais que ocorreram nos Estados de Minas Gerais, São Paulo e Paraná. Procura-se ressaltar as diferenças entre os programas, bem como seus resultados. 
No capítulo 3 é analisada a evolução do reflorestamento nos Estados de Minas Gerais, São Paulo e Paraná, ressaltando a importância dos diferentes programas na promoção do fomento florestal nestes Estados.

O capítulo 4 apresenta, para cada Estado, a rentabilidade absoluta do reflorestamento com eucalipto utilizando análise determinista, análise de sensibilidade e análise de risco por meio do Método de Monte Carlo. Procura-se verificar a importância do tipo de subsídio dado nos programas estaduais sobre a rentabilidade dos reflorestamentos em pequenos e médios imóveis rurais.

No capítulo 5 são apresentadas as conclusões do presente trabalho e sugestões para novas pesquisas. 


\section{PROGRAMAS PÚblicos E PRIVAdOS DE INCENTIVo AO REFLORESTAMENTO EM PEQUENOS E MÉDIOS IMÓVEIS RURAIS}

Esse capítulo analisa os programas públicos, da sociedade civil e privados de incentivo ao reflorestamento em pequenos e médios imóveis rurais que ocorreram e ainda ocorrem nos Estados de Minas Gerais, São Paulo e Paraná.

Procura-se ressaltar as diferentes características e o modo de operação dos programas. São apresentados os resultados alcançados em termos de áreas reflorestadas, mudas distribuídas e produtores beneficiados em cada um dos Estados via os programas públicos, da sociedade civil e os da iniciativa privada.

\subsection{Programas Federais}

Segundo Bacha (1998, p. 28), no dia 23 de janeiro de 1934, o Decreto-Lei Federal $n^{\circ} 23.793$ instituiu o $1^{\circ}$ Código Florestal, adotando medidas que visavam disciplinar o processo de desmatamento no País. O $1^{\circ}$ Código Florestal foi substituído no dia 15 de setembro de 1965 pela Lei Federal $n^{\circ} 4.771$ que institui, por sua vez, o $2^{\circ}$ Código Florestal ${ }^{3}$. Este já continha a indicação do uso de incentivos monetários para estimular o reflorestamento no Brasil.

No período de 1966 a 1988 o Governo Federal realizou três programas de incentivo ao reflorestamento no Brasil: no período de 1965 a 1988 foi realizado o "Programa de Incentivos Fiscais ao Florestamento e Reflorestamento" (PIFFR); na segunda metade da década de 70 foi implementado o "Programa de Incentivo ao Reflorestamento em Pequenos e Médios Imóveis Rurais" (REPEMIR); e, no periodo de

\footnotetext{
${ }^{3}$ Alterada pelas Leis Federais $n^{\circ} 7.803$ e 7.875 de 18/07/89 e 13/1 1/89, respectivamente.
} 
1985 a 1988 o "Programa de Reflorestamento com Algarobeira no Nordeste semi-árido" (Projeto Algaroba).

Segundo Silva (1989) ${ }^{4}$, citado por Bacha $(1995$, p. 72$)$ o Projeto Algaroba apresentou carater regional, sendo realizado no nordeste brasileiro, mais precisamente em regiões semi-áridas. Foi implantado entre os anos de 1985 e 1988 com recursos do FINSOCIAL (Financiamento ao Investimento Social) e BNDES (Banco Nacional de Desenvolvimento Social) e atendeu a 8.300 pequenos produtores rurais reflorestando 18.800 hectares.

No PIFFR o objetivo básico era proporcionar o estabelecimento de grandes maciços florestais para o abastecimento dos grandes consumidores de matéria-prima florestal. Através da Lei $\mathrm{n}^{\circ}$ 5.106/66, que criou os incentivos fiscais ao florestamento e

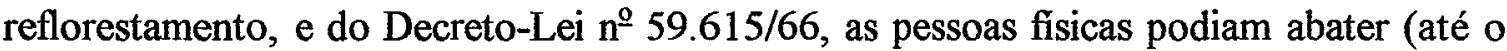
limite de $50 \%$ de sua renda bruta tributável) as importâncias aplicadas no florestamento e reflorestamento no ano-base de tributação. As pessoas jurídicas podiam abater as importâncias aplicadas no reflorestamento até o limite de 50\% do Imposto de Renda devido. Esses limites foram, posteriormente, reduzidos, com · o PIFFR terminando em 1988 (a opção por dedução encerrou-se em 1986 mas os recursos foram liberados até 1988).

Segundo Bacha (1995, p. 60) o PIFFR além de contemplar os agentes econômicos que pagavam imposto de renda - excluindo a grande maioria dos produtores rurais - estabeleceu em vários momentos tamanhos mínimos de plantio que eram elevados em relação à área média das propriedades rurais brasileiras ${ }^{5}$.

Apesar de graves distorções, o PIFFR contribuiu fortemente para o aumento expressivo da área reflorestada do país. Em 1964 havia 500.000 ha de florestas plantadas no Brasil e, em 1984, esse montante era de 5.901.000 ha. Portanto, o "estoque" de florestas plantadas aumentou $1.080 \%$ em 20 anos.

\footnotetext{
${ }^{4}$ Silva, S. Algarobeira (Prosopisjuliflora (Sw) D.C.) no Nordeste do Brasil. Ministério da Agricultura. Secretaria Nacional de Produção Agropecuária. Secretaria de Produção Animal. Brasília, 1989.

${ }^{5}$ Segundo Bacha (1995, p. 62) pelo Decreto-Lei Federal nº $79.046(21 / 12 / 76)$ os projetos deveriam ter uma área mínima de plantio de 1000 ha . Posteriomente reduziu-se o tamanho mínimo do projeto.
} 
Aliado às críticas dispendidas ao PIFFR quanto ao seu caráter excludente, houve a necessidade do Governo Federal em incentivar o uso de insumos energéticos não provenientes do petróleo devido ao " 1 ํㅡㄹ choque do petróleo" ocorrido em 1973. Dessa maneira, o então Instituto Brasileiro de Desenvolvimento Florestal (IBDF) buscou implementar um programa que beneficiasse o pequeno proprietário rural, surgindo o REPEMIR. Este objetivava propiciar a esses proprietários rurais fonte de matéria-prima florestal para uso energético, além da possibilidade de comercialização de eventuais excedentes.

Para operacionalização das atividades do REPEMIR, o IBDF estabeleceu convênios com órgãos estaduais. Esses eram incumbidos de elaborar os projetos de reflorestamento recebendo, para executá-los, recursos do instituto. Todavia, cada órgão estadual tinha a possibilidade de elaborar projetos distintos de reflorestamento, o que imprimiu ao programa características peculiares em cada Estado. Assim, o REPEMIR foi fundamentado na concessão de crédito subsidiado em São Paulo e na doação de mudas, insumos e assistência técnica em Minas Gerais e no Paraná.

Segundo o IBDF/DEF (1980, p. 9) os subsídios oferecidos para a implantação do REPEMIR foram de Cr $\$ 6.000,00$ (seis mil cruzeiros em agosto de 1980$)^{6}$ por hectare, distribuídos em produção e/ou compra de mudas, insumos básicos e assistência técnica.

Para os propósitos definidos neste trabalho, discutem-se as características peculiares do REPEMIR nos Estados de Minas Gerais, São Paulo e Paraná.

\subsubsection{O Programa de Reflorestamento em Pequenos e Médios Imóveis Rurais no Estado de Minas Gerais}

Em Minas Gerais, o REPEMIR teve início no ano de 1976 e foi implementado através de convênio entre o IBDF e o Instituto Estadual de Florestas (IEF-MG). A sistemática adotada no Estado foi a concessão gratuita de mudas, insumos e assistência técnica.

\footnotetext{
${ }^{6}$ Em valores de dezembro de 1999 corresponde à $\mathrm{R} \$ 385,41$ (Deflacionado pelo IGP-DI).
} 
Segundo Carvalho (1995), foram realizadas avaliações do REPEMIR nos diferentes Estados pelo Departamento de Economia do IBDF e Minas Gerais foi considerado o Estado onde o REPEMIR apresentou melhor desempenho, tanto no que concerne a área reflorestada, como na qualidade dos plantios. Através deste programa foram plantados 19.398,32 ha, beneficiando 10.909 agricultores, em Minas Gerais.

\subsubsection{O Programa de Reflorestamento em Pequenos e Médios Imóveis Rurais no Estado de São Paulo}

Em São Paulo, o REPEMIR foi lançado em 1980 objetivando oferecer subsídios ao pequeno e médio produtor rural para o reflorestamento de áreas impróprias às atividades agrícolas. Além disso, procurava amenizar problemas incorridos no PIFFR com a distribuição de recursos referentes aos beneficios fiscais entre diferentes estratos de propriedades no Estado. O REPEMIR foi implementado através de convênio entre a Secretaria da Agricultura e Abastecimento (S.A.A.), Banco do Estado de São Paulo S/A (BANESPA) e Banco de Desenvolvimento do Estado de São Paulo (BADESP).

Segundo Bergamasco \& Bergamasco (1988, p. 84), a sistemática adotada em São Paulo foi a concessão de créditos subsidiados aos proprietários rurais: os financiamentos eram efetuados oferecendo ao produtor juros de $18 \%$ ao ano, capitalizáveis, sem correção monetária e com carência de 8 anos para pagamento. $O$ crédito era liberado em três parcelas, de acordo com o cronograma fixado no projeto. $\mathrm{O}$ pagamento direto aos fornecedores de bens e prestadores de serviços era obrigatório. Além disso, o orçamento do projeto era totalmente financiado e $1 \%$ do valor do empréstimo era acrescido para a elaboração e orientação de cada projeto.

A área total das propriedades rurais beneficiadas não deveria exceder a 300 hectares e o limite máximo a ser reflorestado em cada propriedade era de apenas 20 ha. Além disso, esse limite não deveria exceder a $20 \%$ da área total do imóvel. Em São Paulo foram contratados, através do REPEMIR, 491 projetos que atingiram 5.065,51 ha de área reflorestada. 
Bergamasco \& Bergamasco (1988) apontaram sérias distorções ocorridas no REPEMIR em São Paulo. O limite máximo de 300 ha para a área das propriedades beneficiadas não foi obedecido, verificando-se que aproximadamente $30 \%$ das propriedades beneficiadas excediam a este valor. Entretanto, a área média das propriedades contempladas foi de 278,33 ha, valor bastante aproximado do limite máximo imposto.

Foi detectado um amplo mercado consumidor para a madeira desses reflorestamentos em termos de olarias, fábricas de cerâmicas e indústria de papel e celulose nas diferentes regiões do Estado. Entretanto, Bergamasco \& Bergamasco (1988) averiguaram que, em geral, a maioria dos produtores rurais utilizaram a madeira produzida nos reflorestamentos para a confecção de mourões na propriedade.

Para Bergamasco \& Bergamasco (1988), os projetos implantados só foram viáveis devido ao subsídio oferecido pelo Estado. Segundo os autores, o subsídio também foi o responsável pela baixa produtividade encontrada nos plantios, visto que levou, de certa maneira, a poucos cuidados técnicos.

\subsubsection{O Programa de Reflorestamento em Pequenos e Médios Imóveis Rurais no Estado do Paraná}

O REPEMIR foi lançado no Paraná no ano de 1980, visando, principalmente, o aumento da cobertura florestal junto aos pequenos e médios imóveis rurais. Devido a estrutura fundiária do Estado ${ }^{7}$ uma maneira eficiente de promover a reposição florestal em larga escala seria através de uma política florestal voltada ao pequeno e médio produtor.

O programa foi realizado através do convênio entre o Instituto de Terras e Cartografia (ITC) e a EMATER (Empresa de Assistência Técnica e Extensão Rural do Paraná). A participação do ITC era feita através do gerenciamento do projeto, da produção de mudas e entrega dessas na sede dos diversos municípios. A EMATER,

\footnotetext{
${ }^{7}$ Segundo o IBDF/SEAP (1980) 94,1\% dos imóveis rurais do Paraná possuíam área de até 100 ha na época da implantação do REPEMIR no Estado.
} 
órgão oficial de assistência técnica do Paraná, cadastrava as propriedades e fornecia orientação e acompanhamento na execução do plantio em nível de propriedade. Ao agricultor cabia o preparo do terreno, o transporte das mudas entre a sede municipal e sua propriedade, o combate a formigas, o plantio e os tratos culturais.

Cerca de 10 micro-regiões foram priorizadas e beneficiadas pelo programa, dentre elas o Extremo Oeste Paranaense, o Sudoeste Paranaense e o Norte Novíssimo de Umuarama. Segundo Santos (1988), essas micro-regiões apresentavam, em 1979, a maior concentração de serrarias existentes no Estado além da concentração de remanescentes florestais nativos. A prioridade dada ao reflorestamento dessas microregiões, em especial, revela a preocupação dos órgãos estaduais envolvidos no REPEMIR com o desmatamento crescente dos remanescentes florestais nativos.

De acordo com o IBDF/SEAP (1980) as propriedades rurais beneficiadas pelo REPEMIR possuíam área entre 2 e 100 hectares, podendo ser reflorestados, em cada uma delas, o mínimo de 1 ha e o máximo de 3 ha. As espécies mais utilizadas foram as de rápido crescimento ( $90 \%$ dos plantios eram de Eucalyptus e Pinus) e a densidade dos plantios era de 1.800 árvores por hectare. $O$ plantio com essências nativas correspondeu a $10 \%$ dos plantios.

O objetivo do REPEMIR no Estado do Paraná era reflorestar 2.500 ha, entre os períodos de agosto de 1980 a julho de 1981. Dessa maneira, os recursos previstos foram de $\operatorname{Cr} \$ 15.000 .000,00$ (quinze milhões de cruzeiros, em agosto de 1980$)^{8}$.

\subsection{Programas públicos e privados de fomento florestal no Estado de Minas Gerais}

O governo de Minas Gerais tem longa experiência na implantação de programas de fomento florestal (item 2.2.1) o qual também é executado pelas empresas situadas no Estado, em especial as empresas siderúrgicas (item 2.2.2).

\footnotetext{
${ }^{8}$ Corresponde a $\mathrm{R} \$ 963.529,09$ em valores de dezembro de 1999 (deflacionado pelo IGP-DI).
} 


\subsubsection{Programas públicos estaduais em Minas Gerais}

Segundo Neves (1994), o fomento florestal em Minas Gerais teve início com o "Projeto de Reflorestamento para Produtores Rurais", em 1958, no município de Paraopeba. $\mathrm{O}$ projeto reflorestou 85 ha e beneficiou 92 produtores rurais. A partir dessa experiência, alguns programas estaduais de incentivo aos reflorestamentos foram realizados em Minas Gerais. Foram eles:

- o "Programa de Reflorestamento na região de Ubá", realizado em 1963;

- a "Campanha Integrada de Reflorestamento"- CIR, realizada de 1966 a 1968;

- a "Campanha Estadual de Reflorestamento"- CIER, realizada de 1968 a 1972;

- o "Programa de Desenvolvimento Integrado da Zona da Mata" PRODEMATA, realizado de 1976 a 1983;

- o "Programa Estadual de Promoção de Pequenos Produtores Rurais" - MG II, realizado de 1980 a 1983 ;

- o "Programa de Desenvolvimento Rural Integrado do Noroeste" PLANOROESTE II, realizado de 1981 a 1982, e,

- o "Programa Estadual de Conservação e Produção Florestal" - PRÓFLORESTA, iniciado em 1989.

O "Programa de Reflorestamento na região de Ubá" beneficiou onze municípios na região de Ubá, Zona da Mata mineira. De acordo com Neves (1994), esses municípios apresentavam, na década de 50, cobertura florestal menor que $6 \%$ de sua área. $\mathrm{O}$ solo estava erosado e os cursos d'água assoreados. A iniciativa de promover o reflorestamento na região partiu da então Associação de Crédito e Assistência Rural (ACAR), atual EMATER, que optou por incorporar o reflorestamento em seu programa de extensão. O programa de reflorestamento implantado foi um trabalho que envolveu a participação da EMATER/MG, do Instituto Estadual de Florestas de Minas Gerais (IEF/MG), IBDF (atual IBAMA), prefeituras, sindicatos rurais, cooperativas, imprensa, 
igreja e empresários (Fábrica de Papel de Cataguases e as fábricas de móveis de Ubá e municípios vizinhos). $O$ programa reflorestou 460 ha e beneficiou 307 produtores rurais.

De acordo com Assis et al. (1986), uma das regiões mais aptas à agropecuária no século passado e início do atual era a Zona da Mata mineira que está excepcionalmente localizada em relação aos grandes centros consumidores do país. Esses atrativos provocaram o esgotamento dos recursos florestais da região além do empobrecimento do solo. Em 1963 iniciou-se na região de Ubá um "Plano Piloto de Reflorestamento". O plano original foi alterado buscando a introdução da cultura de eucalipto nas propriedades rurais culminando, assim, na "Campanha Integrada de Reflorestamento para Zona da Mata" (CIR).

Segundo Castro Filho (1991, p. 22), a CIR foi lançada em 1966 e abrangeu a Zona da Mata, Metalúrgica, Rio Doce e Mucuri sendo um dos projetos pioneiros de reflorestamento em nível de propriedades rurais. Inicialmente, os projetos de reflorestamento com eucalipto enfrentavam grandes dificuldades de aceitação por parte dos produtores rurais as quais advinham de questões culturais. $O$ eucalipto era visto como uma espécie arbórea causadora de seca dos solos e mananciais. Não obstante, entre 1966 e 1968 foram reflorestados $4.710,5$ ha, beneficiando 2.672 produtores rurais, dentro da CIR.

No período de 1968 a 1972 foi executada a Campanha Estadual de Reflorestamento (CIER), a qual beneficiou 4.562 produtores rurais e reflorestou 9.052 ha.

No período de 1973 a 1975, o Governo de Minas Gerais não executou nenhum programa de estimulo ao reflorestamento. Isto só voltou a ocorrer no PRODEMATA, em 1976.

Segundo Carvalho (1995), o PRODEMATA foi lançado em 1976 pelo Governo do Estado e pelo BIRD (Internacional Bank for Reconstruction and Development). Seu principal objetivo era o aproveitamento de terras consideradas ociosas e inaproveitáveis para a agropecuária na região da Zona da Mata mineira. $\mathrm{O}$ reflorestamento buscou 
oferecer ao pequeno e médio proprietário rural uma fonte de matéria-prima florestal para uso próprio e/ou comercialização e também o aproveitamento de mão-de-obra existente nos minifúndios da região.

Assis et al. (1986) observaram que a maioria dos proprietários beneficiados pelo PRODEMATA adotaram técnicas simples na implantação $e$ manutenção dos reflorestamentos. Para os autores, a falta de equipamentos de maior rendimento operacional, de orientação técnica e a localização dos plantios em terrenos declivosos foram, em ordem decrescente, as maiores dificuldades encontradas pelos agricultores. Esses autores concluíram que o IEF poderia ter suprido a falta de orientação técnica de alguma maneira, seja ela pelo treinamento de agentes de campo ou até mesmo através de cartilhas explicando de uma maneira simplificada as técnicas e cuidados a serem tomados na exploração dos reflorestamentos.

Apesar das dificuldades, Carvalho (1995) contabilizou o reflorestamento de 24.601,49 hectares com 14.072 agricultores beneficiados pelo PRODEMATA, além da estimativa de criação de 6.642 empregos diretos.

Segundo Carvalho \& Araújo (1985), o êxito do PRODEMATA levou o IEF a estender os programas de fomento florestal a outras regiões do Estado através de outros programas, como o MG II e o PLANOROESTE II. O "Programa Estadual de Promoção de Pequenos Produtores Rurais" (MG II), instituído como um segmento do PRODEMATA, foi criado em 1980 e beneficiou, principalmente, o Alto do Jequitinhonha, o Campo da Vertentes, o Mucuri, o Centro-Oeste e o Sul de Minas. A área plantada foi de $6.704,19$ hectares, beneficiando 6.386 agricultores.

Também foi instituído o PLANOROESTE II, "Programa de Desenvolvimento Rural Integrado do Noroeste", iniciado em outubro de 1981 e com término em 1987. O PLANOROESTE II contemplou municípios do Noroeste do Estado efetuando o plantio de $2.001,20$ hectares e beneficiando 1.459 agricultores (observe os resultados alcançados pelos programas públicos de fomento florestal na tabela 1 ). 
No período de 1984 a 1988, o Governo de Minas Gerais não executou programas próprios de estímulo ao reflorestamento em pequenos e médios imóveis rurais, preferindo estimular grandes empresas consumidoras de matéria-prima florestal a fazêlo.

Tabela 1 - Resultados alcançados pelos programas federal e estaduais de estímulo ao reflorestamento nos pequenos e médios proprietários rurais no Estado de Minas Gerais situação em meados da década de 80.

\begin{tabular}{c|c|c|c|c|c}
\hline Programas & Período & $\begin{array}{c}\text { No de } \\
\text { mudas } \\
\text { entregues } \\
\text { (mil) }\end{array}$ & $\begin{array}{c}\text { Área } \\
\text { Reflorestada } \\
\text { (ha) }\end{array}$ & $\begin{array}{c}\text { Agricultores } \\
\text { beneficiados }\end{array}$ & $\begin{array}{c}\text { Área } \\
\text { reflorestada / } \\
\text { proprietário } \\
\text { (ha) }\end{array}$ \\
\hline Fomento Florestal em Paraopeba & 1958 & - & 85 & 92 & 0,92 \\
Fomento Florestal na região de Ubá & 1963 & - & 460 & 307 & 1,50 \\
CIR & 1966 a 1968 & - & $4.710,50$ & 2.672 & 1,76 \\
CIER & 1968 a 1972 & - & $9.052,00$ & 4.562 & 1,98 \\
PRODEMATA $^{*}$ & 1976 a 1983 & $46.926,55$ & $24.601,49$ & 14.072 & 1,75 \\
REPEMIR & 1978 a 1981 & $40.939,01$ & $19.398,32$ & 10.909 & 1,80 \\
MG II & 1980 a 1983 & $13.421,01$ & $6.704,19$ & 6.386 & 1,05 \\
PLANOROESTE II & 1981 a 1982 & $3.996,29$ & $2.001,20$ & 1.459 & 1,37 \\
\hline TOTAL & - & $105.282,86$ & $67.012,70$ & 40.459 & 1,66 \\
\hline
\end{tabular}

Fonte: elaborado a partir de dados obtidos junto ao IEF, Castro Filho (1991) e Carvalho (1995) *O PRODEMATA também estimulou o plantio de 1.462 ha de árvores nativas em 1.634 estabelecimentos rurais

Em 1989, iniciou-se o PRÓ-FLORESTA que, assim como o PRODEMATA, o MG II e o PLANOROESTE II, tem como parte de seus objetivos o reflorestamento em pequenas e médias propriedades rurais visando o suprimento dessas com matéria-prima florestal e a possibilidade de comercialização do excedente pelo produtor. O PRÓFLORESTA teve financiamento parcial do Banco Mundial entre os períodos de 1989 e 1996. A partir daí, os recursos orçamentários do Governo de Minas Gerais e do "Fundo Pró-floresta" dão continuidade ao programa.

O PRÓ-FLORESTA possui duas linhas de atuação. Na primeira, busca o incentivo ao reflorestamento e o faz através de dois projetos específicos. Um que realiza empréstimos a grandes consumidores de madeira para que os mesmos realizem o reflorestamento e outro que procura dar fomento ao reflorestamento de pequenos e 
médios imóveis rurais. Na segunda linha de atuação, o programa busca a conservação de recursos florestais através de cinco projetos específicos: o mapeamento da cobertura vegetal de Minas Gerais; a implantação da infra-estrutura nas unidades de conservação; a realização de educação ambiental; a criação de mecanismos de prevenção de incêndios florestais; e a reformulação e modernização da estrutura do Instituto Estadual de Florestas (IEF).

Segundo o World Bank (1997), a meta para o reflorestamento em pequenos e médios imóveis rurais era o plantio de 41.300 ha em oito anos (82\% seria com eucalipto e o restante com espécies nativas). O PRÓ-FLORESTA, entretanto, incentivou o plantio de 51.893 hectares com florestas exóticas e nativas e beneficiou 25.167 produtores (observe a tabela 2). A previsão inicial de recursos necessários foi de US\$ 6,4 milhões mas a decisão do IEF em reduzir o subsídio aos fertilizantes e usar inseticidas com custos menores resultaram na poupança de US\$1,6 milhão.

Tabela 2 - Resultados alcançados no período de 1989 a 1996 com o reflorestamento junto a pequenos e médios imóveis rurais com recursos do Fundo Pró-Floresta - Minas Gerais.

\begin{tabular}{llcccccc}
\hline & Anos & $\begin{array}{c}\text { Area } \\
\text { reflorestada } \\
\text { (ha) }\end{array}$ & $\begin{array}{c}\text { Agricultores } \\
\text { beneficiados }\end{array}$ & $\begin{array}{c}\text { Mudas } \\
\text { produzidas } \\
\text { (mil) }\end{array}$ & $\begin{array}{c}\text { Mudas } \\
\text { distribuídas } \\
\text { (mil) }\end{array}$ & $\begin{array}{c}\text { Insumos } \\
\text { distribuídos } \\
\text { (ton) }\end{array}$ & $\begin{array}{c}\text { Produtores } \\
\text { assistidos }\end{array}$ \\
\hline E & $1989 / 90$ & 4.539 & 1.521 & 12.307 & 9.527 & 155 & 1.177 \\
U & $1990 / 91$ & 8.464 & 3.120 & 23.255 & 18.278 & 452 & 1.348 \\
A & 1992 & 7.617 & 2.187 & 23.236 & 15.187 & 514 & 1.898 \\
L & 1993 & 9.728 & 3.084 & 22.905 & 19.137 & 624 & 2.035 \\
I & 1994 & 9.415 & 3.404 & 19.533 & 18.616 & 562 & 2.143 \\
P & 1995 & 3.950 & 4.962 & n.d. & n.d. & n.d. & n.d. \\
T & 1996 & 10.734 & 1.203 & n.d. & n.d. & n.d. & n.d. \\
\hline D & Total & 54.447 & 19.481 & 101.336 & 80.745 & 2.307 & 8.601 \\
\hline & Meta & 34.000 & 15.000 & 81.600 & 70.000 & 3.470 & 15.000 \\
\hline & $1989 / 90$ & 382 & 221 & 190 & 112 & 24 & 217 \\
N & $1990 / 91$ & 588 & 347 & 327 & 264 & 30 & 282 \\
A & 1992 & 340 & 243 & 326 & 114 & 17 & 203 \\
I & 1993 & 890 & 610 & 639 & 325 & 35 & 549 \\
V & 1994 & 1.225 & 1.054 & 772 & 500 & 28 & 755 \\
A & 1995 & 4.755 & 4.414 & n.d. & n.d. & n.d. & n.d. \\
S & 1996 & 835 & 1.363 & n.d. & n.d. & n.d. & n.d. \\
\hline & Total & 9.015 & 8.252 & 2.781 & 2.671 & 188.5 & 3.184 \\
\hline & Meta & 7.320 & 3.000 & 4.758 & 3.660 & 805 & 3.000 \\
\hline
\end{tabular}

Fonte: pesquisa do autor junto ao BDMG e IEF 
Com o financiamento do PRÓ-FLORESTA pelo Governo Estadual e com recursos do Fundo Pró-Floresta a partir de 1997, novas metas foram estabelecidas. Segundo Bacha (1998) essa segunda fase do programa busca o plantio anual de 38.400 hectares em pequenos e médios imóveis rurais, sendo 21.600 ha de florestas exóticas e 12.900 de florestas nativas (estas últimas para fins de proteção e conservação, como é o caso das matas ciliares).

$\mathbf{O}$ fomento florestal realizado pelo Instituto Estadual de Florestas é feito através de parceria com os proprietários rurais do Estado de Minas Gerais. Basicamente, existem duas linhas de atuação. Na primeira o IEF incentiva a implantação de florestas de produção nas propriedades rurais buscando, principalmente, a diversificação de atividades e a possibilidade de aumento da renda do produtor rural (observe os resultados alcançados na tabela 3 ). Na segunda linha de atuação, o instituto busca promover a preservação de florestas nativas, dos recursos naturais (cursos d'água e nascentes) e da biodiversidade através de florestas de proteção.

Tabela 3 - Resultados alcançados no período de 1998 a 1999 com florestas de produção (plantio de Eucalipto e Pupunha) - Minas Gerais.

\begin{tabular}{|c|c|c|c|c|}
\hline Anos & $\begin{array}{l}\text { Area reflorestada } \\
\text { (ha) }\end{array}$ & $\begin{array}{l}\text { Agricultores } \\
\text { beneficiados }\end{array}$ & $\begin{array}{c}\mathrm{N}^{0} \text { de mudas } \\
\text { distribuídas (unidade) }\end{array}$ & $\begin{array}{c}\text { Assistência técnica } \\
\text { prestada }\end{array}$ \\
\hline 1998 & $4.921,68$ & 1.892 & 8.877 .107 & 1.180 \\
\hline 1999 & $5.093,22$ & 1.850 & 9.348 .550 & 1.456 \\
\hline
\end{tabular}

Fonte: IEF (2000)

Pode-se constatar na tabela 3 que a meta estabelecida na nova fase do PRÓFLORESTA de fomentar o plantio de 21.600 ha por ano com florestas exóticas não tem sido atingida.

O plantio de espécies nativas no Estado de Minas Gerais por parte de pequenos e médios produtores apresentava mais dificuldades devido, principalmente, ao seu crescimento mais lento e menor retorno financeiro. Reconhecendo isso e focalizando a distribuição das mudas nativas na proteção de microbacias e nas margens dos rios o IEF deu origem, dentro do PRÓ-FLORESTA, ao "Programa de matas ciliares", lançado em 1994 (observe os resultados na tabela 4). 
Tabela 4 - Resultados alcançados no período de 1994 a 1998 com florestas de Conservação (Matas Ciliares) - Minas Gerais.

\begin{tabular}{ccc}
\hline Períodos & Área reflorestada (ha) & Agricultores beneficiados (unidade) \\
\hline $1994 / 95$ & 702,40 & 254 \\
$1995 / 96$ & $2.054,20$ & 1.082 \\
$1996 / 97$ & $1.172,00$ & 1.172 \\
$1997 / 98$ & $1.286,50$ & 1.354 \\
$1998 / 99$ & 988,23 & 1.296 \\
\hline
\end{tabular}

Fonte: IEF (2000)

Segundo World Bank (1997, p. 35) o programa de matas ciliares busca a reabilitação de margens de rios degradadas e a proteção de mananciais e leitos de água.

Além do programa de matas ciliares o IEF, através do envolvimento dos governos municipais, associação de produtores e organizações não-governamentais, vem implantando florestas de proteção em áreas degradadas e matas de topos (veja os dados da tabela 5).

Tabela 5 - Resultados alcançados no período de 1989 a 1999 com florestas de proteção - matas ciliares, proteção de nascentes, áreas degradadas e matas de topo (Minas Gerais).

\begin{tabular}{cccc}
\hline Períodos & Área reflorestada (ha) & Períodos & Área reflorestada (ha) \\
\hline $1989 / 90$ & 374 & $1994 / 95$ & 1.710 \\
$1990 / 91$ & 532,5 & $1995 / 96$ & 2.207 \\
$1991 / 92$ & 224 & $1996 / 97$ & $2.927,70$ \\
$1992 / 93$ & 601 & $1997 / 98$ & $1.934,30$ \\
$1993 / 94$ & 1.102 & $1998 / 99$ & $1.816,26$.
\end{tabular}

Fonte: IEF (2000)

Pode-se observar pelos dados da tabela 5 que também a meta estabelecida no PRÓ-FLORESTA de plantar anualmente 12.900 ha de florestas nativas não tem sido atingida. 


\subsubsection{Programas privados de fomento florestal em Minas Gerais}

De acordo com Ferretti (2000, p. 14), a política de incentivos fiscais aos reflorestamentos foi encerrada pelo Congresso Nacional com a aprovação da Medida Provisória no 21/88, transformada em Lei Federal no 7.714/88. A partir daí, a adoção de programas de fomento florestal por parte de empresas privadas consumidoras de madeira se fez cada vez mais presente, principalmente no Estado de Minas Gerais. Do ponto de vista das empresas siderúrgicas e de papel e celulose existentes no Estado, o fomento florestal tornou-se uma alternativa de ampliação das áreas reflorestadas sem a respectiva imobilização de capital em terras. Assim, o fomento florestal permite o aumento da oferta de matéria-prima florestal sem os correspondentes gastos em infra-estrutura e pessoal por parte da empresa fomentadora.

Para os produtores rurais, entretanto, o fomento possibilita diretamente a incorporação de terras ociosas ao processo produtivo, o uso da matéria-prima florestal na propriedade e o emprego da mão-de-obra local.

As primeiras empresas que demonstraram interesse em efetuar o fomento florestal no Estado de Minas Gerais, atuando em convênio com o IEF, foram:

- Em 1981 - Projeto IEF/CVRD - Companhia Vale do Rio Doce;

- Em 1985 - Projeto IEF/CENIBRA - Celulose Nipo-Brasileira;

- Em 1985 - Projeto IEF/CAF - Companhia Agrícola e Florestal Santa Bárbara;

- Em 1986 - Projeto IEF/MATARAZZO - Indústrias Matarazzo de Papéis.

Basicamente, esses convênios foram estabelecidos buscando a garantia do suprimento da matéria-prima florestal necessária às empresas (veja o quadro 1). Além disso, o grande interesse das empresas foi pela possibilidade de aumento da oferta de madeira em áreas próximas às suas plantas industriais. 


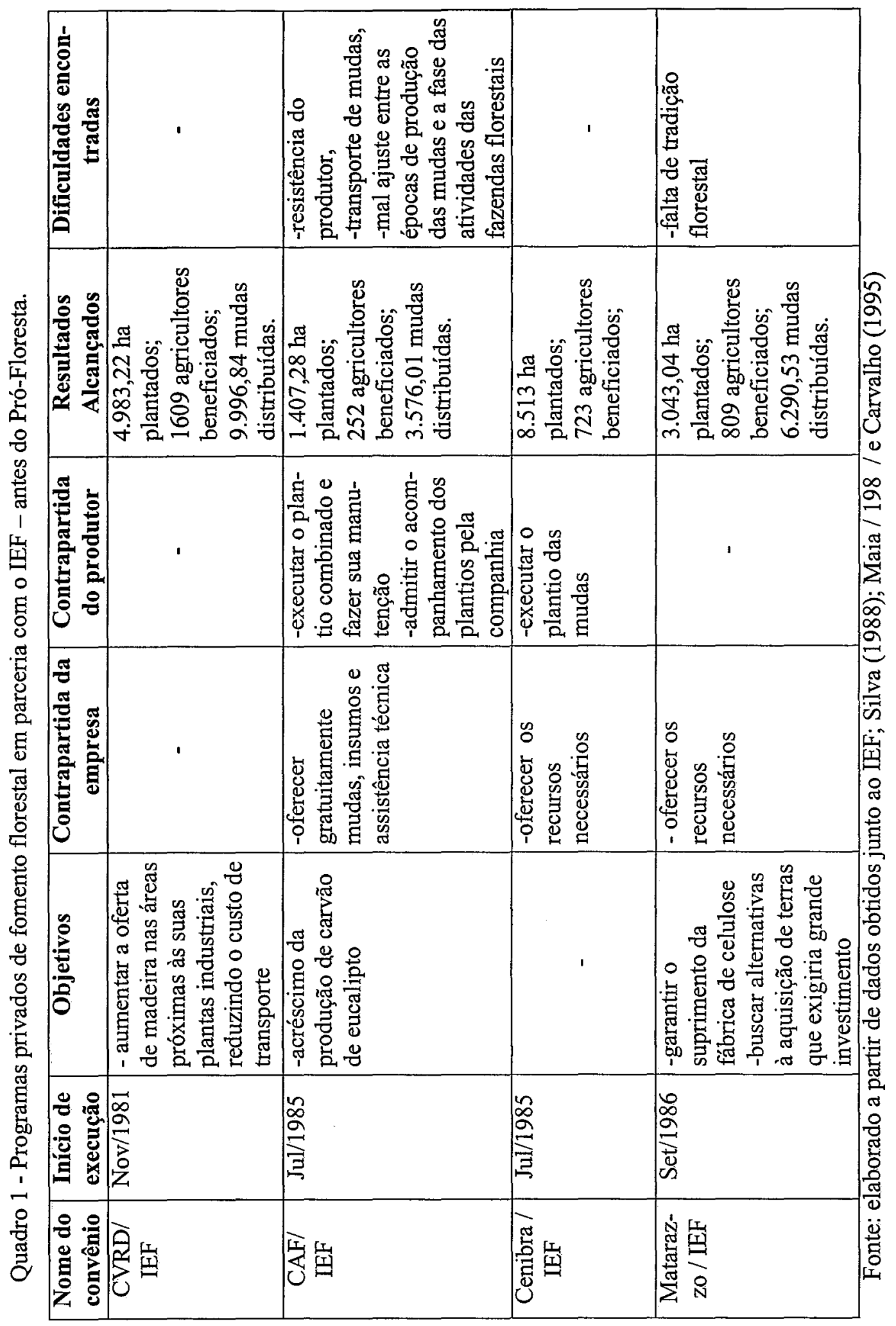


Às empresas consumidoras de madeira coube proporcionar os recursos necessários à implantação e manutenção das florestas. De uma maneira em geral, todas elas financiaram a produção de mudas e insumos necessários além de oferecerem assistência técnica gratuita. Elas foram responsáveis pelo transporte da madeira e tinham a preferência de compra dos produtos florestais (observe no quadro 1 as características específicas a cada convênio estabelecido).

O IEF atuou nesses convênios selecionando os proprietários rurais e distribuindo as mudas e insumos necessárịos à implantação e manutenção das florestas. O fomento promovido pela CVRD foi denominado PRODEFLOR e efetuado na região do Rio Doce. Em média a área reflorestada foi de 3 ha por propriedade. No convênio Matarazzo/IEF, o instituto atuou também oferecendo assistência técnica junto ao produtor rural.

As responsabilidades designadas ao produtor rural eram a execução do plantio combinado e a sua devida manutenção. No convênio CAF/IEF foi estabelecido em contrato o direito da empresa de acompanhar o plantio das mudas.

Segundo Carvalho (1995, p. 40), o Estado passou a financiar, a partir de 1987, projetos privados de fomento florestal utilizando uma linha de crédito do BDMG Banco de Desenvolvimento de Minas Gerais, implementada com recursos do PRÓFLORESTA. Esses projetos são denominados "Fazendeiros Florestais". Várias empresas dos segmentos de papel e celulose e siderurgia a carvão vegetal (além das citadas no quadro 1) estão suprindo parte de suas necessidades através da parceria com os proprietários rurais. O IEF participa na supervisão dos projetos. Os resultados alcançados por esses projetos estão na tabela 6 . 
Tabela 6 - Área reflorestada através do Programa Fazendeiro Florestal em Minas Gerais.

\begin{tabular}{cccc}
\hline Período & Área reflorestada (ha) & Período & Área reflorestada (ha) \\
\hline Até 1987 & 4.583 & 1993 & 7.564 \\
1988 & 3.374 & 1994 & 6.502 \\
1989 & 9.989 & 1995 & 6.323 \\
1990 & 12.378 & 1996 & 5.831 \\
1991 & 7.976 & 1997 & 6.536 \\
1992 & 13.244 & 1998 & 9.171 \\
\hline
\end{tabular}

Fonte: Abracave (vários números)

Segundo Albuquerque (1993, p. 69)

“(...) os contratos estabelecidos entre as empresas e os fazendeiros florestais apresentam certas convergências entre si, variando, em sua grande maioria, nos capítulos referentes à exploração florestal e ào ressarcimento do investimento feito pelas empresas para a implantação do projeto".

De maneira em geral, nas parcerias estabelecidas dentro do Programa Fazendeiro Florestal, a empresa financiadora oferece as mudas, formicidas e adubos utilizados no plantio e presta assistência técnica aos produtores rurais. Todavia, esse investimento realizado pelas empresas financiadoras é ressarcido pelo produtor rural na forma de doação de um percentual da madeira produzida na propriedade para a empresa. Também é estabelecido em contrato a garantia de compra da madeira obtida no primeiro corte pela empresa financiadora. Segundo Albuquerque (1993), as diferenças contratuais referentes a compra da madeira estão basicamente no preço da madeira negociado. Isto porque ele é determinado com base na obrigatoriedade ou não, ao produtor rural, da exploração e entrega da madeira nos depósitos da empresa.

Existem casos onde não existe o comprometimento da venda da madeira obtida nos segundo e terceiro cortes para a empresa financiadora. $O$ que existe é apenas a preferência de venda estipulada entre produtor rural e empresa para a madeira oriunda desses cortes. 


\subsection{Programas da sociedade civil e privados de fomento florestal no Estado de São Paulo}

Existem no Estado de São Paulo dois programas, não governamentais, de reposição florestal: o programa de reposição florestal realizado pelas associações de recuperação florestal e o programa de reposição florestal realizado pela Companhia Energética de São Paulo (CESP). Além disso, existem ainda os reflorestamentos fomentados por empresas da iniciativa privada, principalmente, do segmento de papel e celulose.

Não se tem documentado para o Estado de São Paulo um programa oficial de fomento florestal. No entanto, tem-se conhecimento de que o Estado distribuiu, no passado, de forma não contínua ou sistemática, mudas florestais aos produtores. No entanto, não há registros disponíveis sobre este tipo de fomento.

\subsubsection{Programa de reposição florestal realizado pelas Associações de Recuperação Florestal em São Paulo}

A reposição florestal no Estado de São Paulo também ocorre a partir das atividades executadas pelas Associações de Recuperação Florestal (ARFs). Empresas que utilizam madeira para consumo energético ou outras aplicações são legalmente obrigadas a implantar reflorestamentos para suprir o que consomem. Evidentemente que, agindo isoladamente, muitas destas empresas não dispõem de recursos para 0 investimento em reflorestamentos. Para o caso dessas empresas é permitido pagarem ao órgão florestal, ou a entidade por ele cadastrado, o valor correspondente ao que deve ser reflorestado.

No Estado de São Paulo, o pequeno e médio consumidor de madeira tem a opção de efetuar a reposição florestal através das ARFs. Essas funcionam como um agente intermediador incumbindo-se, de um lado, do plantio florestal obrigatório a que estão sujeitos os pequenos e médios consumidores de matéria-prima florestal e utilizando, por outro lado, áreas de pequenos e médios produtores rurais. 
Institucionalmente, as ARFs são organizações de pequenos e médios consumidores de matéria-prima florestal (como padarias, olarias, pizzarias, cerâmicas, entre outros) que não possuem área própria e se vêem, individualmente, impossibilitados ao cumprimento da legislação pertinente (Lei Federal 4.771 de 15/09/65 - 2ํㅡódigo Florestal) no que diz respeito à reposição florestal. A eles associam-se os produtores rurais interessados em realizar o reflorestamento.

Nas palavras de Andrews (1991, p. 58):

“Essas associaçõ̃es são entidades civis, sem fins lucrativos, que congregam pessoas físicas e jurídicas consumidoras de matéria-prima florestal com um consumo de até 12.000 estéreos de lenha por ano ${ }^{9}$ e pessoas interessadas na conservação dos recursos florestais".

Segundo Gonçalves \& Ventura (1992), a partir de 1989, com a portaria do IBAMA $\mathrm{n}^{\circ} 710$, as ARFs foram autorizadas a receberem os valores equivalentes a reposição florestal dos pequenos e médios consumidores de matéria-prima florestal. As associações recebem esses recursos monetários dos consumidores de matéria-prima florestal e repassam aos proprietários rurais, gratuitamente, mudas e assistência técnica. Em contrapartida, o agricultor sede mão-de-obra e terra, além de se responsabilizar pelo desenvolvimento dos plantios. Operacionalmente, o consumidor de matéria-prima florestal recolhe, anualmente, o valor da reposição florestal obrigatória (atualmente isso deve ser feito até $31 / 05$ de cada ano). O consumo é declarado pela empresa ao DEPRN (Departamento de Estadual de Proteção dos Recursos Naturais Renováveis) e ao IBAMA e é convertido em número de árvores a serem recolhidas anualmente ${ }^{10}$. Através de resolução conjunta IBAMA/SMA (Secretaria do Meio Ambiente do Estado de São Paulo) é determinado um valor-árvore (atualmente este valor-árvore é de $\mathrm{R} \$ 0,30$ ).

\footnotetext{
${ }^{9}$ Isto equivale a $8.000 \mathrm{~m}^{3}$ de madeira e $4.000 \mathrm{mdc}$ por ano.

${ }^{10}$ Para cada metro cúbico sólido de madeira consumida, a reposição obrigatória corresponde a seis árvores. Da mesma maneira, para cada metro cúbico de carvão consumido, a reposição obrigatória corresponde a 7,2 árvores. Para cada metro cúbico de lenha consumida, a reposição obrigatória corresponde a 5 árvores. Assim, para que a necessidade de reposição florestal seja transformada em recursos financeiros que possam cobrir os custos das atividades das associações, um "valor-árvore" é estabelecido em reais.
} 
As ARFs se estabelecem por região dentro do Estado de São Paulo. O caráter regional de atuação da $\mathrm{ARF}$, entretanto, não impede que esta tenha participação de associados que não pertençam a região onde se encontra sediada a associação. Ou seja, não existe um limite espacial delimitado (um raio de atuação) entre as associações. Dessa maneira, muitas vezes existe numa mesma região participantes de várias associações.

Os produtos resultantes dos reflorestamentos são de propriedade dos agricultores, não havendo o compromisso de venda obrigatória às associações ou aos consumidores a elas associados. Além disso, as Associações de Recuperação Florestal não conseguem criar condições de exploração, transporte e comercialização da madeira dos reflorestamentos fomentados.

A maioria dos plantios incentivados pelas associações são de florestas homogêneas com espécies exóticas (principalmente, eucalyptus e pinus). A produção de madeira é, em geral, para fins energéticos - embora existam plantios de espécies nativas para fins de recuperação de matas ciliares. Segundo Andrews (1991) dos recursos recolhidos pelas associações o limite máximo de $5 \%$ pode ser destinado à recuperação de matas ciliares (resolução SMA 03/90 da Secretaria do Meio Ambiente do Estado de São Paulo, que regulamentou o funcionamento das ARFs no Estado).

Ainda segundo Andrews (1991), entre os anos de 1987 e 1991 houve um déficit de 609.427 árvores (equivalente a 365,7 hectares) no que deveria ter sido fomentado por cinco associações paulistas de recuperação florestal (Flora Tietê, Flora Verde, Flora Paulista, Flora Cantareira e FLORESPI). Esse não cumprimento das obrigações por parte das ARFs já fez com que quatro destas associações fossem descredenciadas pelo DEPRN por não ter cumprido metas de plantio estipuladas.

Esse descredenciamento de ARFs que não cumprem com suas obrigações tem, por outro lado, um ponto positivo que é o fato da fiscalização do DEPRN ser punitiva. No entanto, há que se ressaltar a carência deste órgão de recursos humanos e materiais necessários para realizar de modo rápido a fiscalização das atividades das ARFs. 
Na tabela 7 tem-se os resultados dos plantios fomentados pelas ARFs.

Tabela 7 - Atividades realizadas com o fomento florestal nas Associações de Recuperação Florestal no Estado de São Paulo.

\begin{tabular}{ccccc}
\hline Anos & Árvores Arrecadadas & Arvores plantadas & Projetos & Hectares \\
\hline 1987 & 228.926 & 291.010 & 76 & 135,00 \\
1988 & 1.022 .236 & 818.310 & 111 & 355,07 \\
1989 & $2.521 .403,50$ & 2.438 .937 & 319 & $1.158,84$ \\
1990 & 2.073 .573 & 2.356 .857 & 398 & 998,41 \\
1991 & $3.619 .168,86$ & 4.171 .811 & 783 & $1.920,52$ \\
1992 & $3.855 .849,78$ & 4.016 .938 & 735 & $1.835,95$ \\
1993 & $5.591 .857,48$ & 3.906 .655 & 639 & $2.637,21$ \\
$1994^{\mathrm{E}}$ & 7.662 .231 & 6.029 .252 & n.d. & $2.804,30$ \\
$1995^{\mathrm{E}}$ & 5.417 .079 & 5.996 .287 & n.d. & $2.788,97$ \\
$1996^{\mathrm{E}}$ & 6.041 .691 & 6.101 .416 & n.d. & $2.837,87$ \\
\hline
\end{tabular}

Fonte: pesquisa do autor junto a FARESP e DEPRN

${ }^{\mathrm{E}}$ valores estimados pela Comissão de Reposição Florestal do Estado de São Paulo

No período de 1989 a 1995 a área anualmente reflorestada pelas ARFs foi de 2.021 ha. Para efeito de comparação, o PRÓ-FLORESTA em Minas Gerais fomentou no mesmo período a média anual de 6.245 ha de florestas exóticas (observe a tabela 2). Esta diferença de resultados deve-se, em parte, às disponibilidades financeiras desses programas. As ARFs em São Paulo só contam com a taxa de reposição florestal de seus associados. Em Minas Gerais, o PRÓ-FLORESTA conta com recursos orçamentários, a taxa de reposição florestal e, no passado, com empréstimos internacionais.

Atualmente, o Estado de São Paulo conta com 19 associações de recuperação florestal credenciadas pelo Departamento Estadual de Proteção de Recursos Naturais (DEPRN) da Secretaria do Meio Ambiente de São Paulo, conforme exposto na tabela 8.

A maioria dessas associações faz parte da FARESP (Federação das Associações de Recuperação Florestal do Estado de São Paulo). No entanto, divergências entre elas fizeram com que em novembro de 1999 fosse criado o "Consórcio Interassociativo de Reposição Florestal Paulista" - CONIN. Este tem como objetivo principal dar suporte às associações consorciadas no cumprimento da Reposição Florestal no Estado de São Paulo. É uma parceria entre as associações de reposição florestal: Florespi, Flora Tietê e Flora Vale. 
Tabela 8 - Associações de Recuperação Florestal do Estado de São Paulo.

\begin{tabular}{|c|c|}
\hline Nome & Sede \\
\hline $\begin{array}{l}\text { 1) FLORA TIETE - Associação de Recuperação Florestal do Médio Tietê } \\
\text { 2) FLORA CANTAREIRA - Associação de Recuperação Florestal das Bacias dos Rios } \\
\text { Jaguari, Atibaia, Camanducaia e Sistema Cantareira } \\
\text { 3) FLORA VERDE - Associação de Recuperação Florestal Sul Paulista } \\
\text { 4) FLORESPI - Associação de Recuperação Florestal da Bacia do Rio Piracicaba e região } \\
\text { 5) ACIFLORA - Associação Florestal e Ecológica da Região de Bauru } \\
\text { 6) VERDE TAMBAÚ - Associação de Reposição Florestal do Pardo Grande } \\
\text { 7) EMA - Empreendimentos Madeireiros Associados } \\
\text { 8) FLORA VALE - Associação de Recuperação Florestal do Médio Paranapanema } \\
\text { 9) FLORA PAULISTA - Associação Paulista de Recuperação e Preservação da Ecologia } \\
\text { 10) FLORA DO RIO GRANDE - Associação de Recuperação Florestal do Vale do Rio } \\
\text { Grande } \\
\text { 11) FLORERC - Associação de Reposição Florestal do Rio Corumbatai } \\
\text { 12) ECOAR - Instituto Ecoar para Cidadania } \\
\text { 13) ARFLOM - Associação de Reflorestamento da Serra da Mantiqueira } \\
\text { 14) ACERVIR - Associação Cerâmicas Vermelhas de Itu e Região } \\
\text { 15) PONTAL FLORA - Associação de Recuperação Florestal do Pontal do } \\
\text { Paranapanema } \\
\text { 16) FLORA PARAÍBA - Associação de Recuperação Florestal do Vale do Paraiba e } \\
\text { Litoral Norte } \\
\text { 17) TRÓPICA FLORA - Associação de Reposição Florestal Trópica Flora } \\
\text { 18) FLORA MANCHESTER - Associação de Recuperação Florestal e Ecológica da } \\
\text { Região de Sorocaba } \\
\text { 19) VITAL FLORA - Associação de Reflorestamento do Noroeste do Estado de São } \\
\text { Paulo }\end{array}$ & $\begin{array}{c}\text { Franca } \\
\text { Rio Claro } \\
\text { São Paulo } \\
\text { Pindamonhangaba } \\
\text { Itu } \\
\text { Presidente Venceslau } \\
\text { São José dos Campos } \\
\text { Jundiaí }\end{array}$ \\
\hline
\end{tabular}

Fonte: pesquisa do autor junto ao DEPRN (1999)

\subsubsection{Programa de reposição florestal realizado pela CESP em São Paulo}

A Companhia Energética de São Paulo (CESP), com o objetivo de armazenar água para o acionamento das usinas hidrelétricas, necessita da construção de grandes lagos artificiais. A construção de barragens e reservatórios para geração hidrelétrica resulta num processo de desmatamento. Além disso, este tipo de construção gera outros impactos ambientais, principalmente sobre a vegetação natural existente nas ilhas e margens dos reservatórios criados.

Segundo Fernandes (1985, p. 52), a área dos reservatórios da CESP atinge cerca de $15.000 \mathrm{Km}$ e, diante desta extensão, um trabalho exaustivo deve ser estabelecido para promover a regeneração da vegetação primária.

Para amenizar o processo de desmatamento ocorrido com as atividades que realiza, a CESP possui um programa cujo objetivo principal é a recomposição e 
conservação dos ecossistemas atingidos. Uma das principais atividades do programa é a recomposição vegetal com espécies florestais nativas.

Duas estratégias para implantação dos reflorestamentos são utilizadas: a primeira é a implantação e manutenção de florestas mistas em áreas de domínios da empresa e a segunda é o fomento florestal. Na primeira alternativa, as áreas focalizadas são, principalmente, as ilhas e margens dos reservatórios, além de áreas de empréstimos de solo $^{11}$. O reflorestamento é implantado, em sua totalidade, com recursos próprios da empresa. $\mathrm{Na}$ tabela 9 está o histórico das áreas reflorestadas com espécies nativas e com recursos próprios da CESP.

Através do fomento florestal são reflorestadas as áreas situadas fora do domínio da CESP mas cuja influência afeta seu trabalho de conservação ambiental. O fomento florestal nada mais é do que uma parceria entre a empresa e proprietários rurais estabelecidos em áreas de influência dos reservatórios. Mediante contrato celebrado entre as partes, a empresa fornece o projeto técnico, as mudas de espécies nativas regionais e a assistência técnica necessários à implantação do reflorestamento. Ao proprietário rural cabe o fornecimento de insumos, mão-de-obra e a área para plantio.

Tabela 9 - Área reflorestada (ha) com recursos próprios da CESP no Estado de São Paulo

\begin{tabular}{cc}
\hline Período & Área reflorestada (ha) \\
\hline 1978 a 1994 & $5.436,94$ \\
1995 & 259,51 \\
1996 & 447,00 \\
1997 & $1.103,20$ \\
1998 & 816,80 \\
\hline Total $\quad$. & $8.063,45$
\end{tabular}

Fonte: CESP (1999)

Segundo Ferretti (2000, p. 67), existe muita dificuldade por parte da CESP em contactar os proprietários rurais nas áreas de influência de seus reservatórios, devido à grande amplitude da área e a falta de equipamentos e corpo técnico para a realização

"Empréstimo de Solo é a área em que se retira solo para construção do aterro de uma barragem. 
dessa tarefa. Assim, de modo em geral, são os proprietários que procuram a CESP. Segundo o autor, as razões para tanto são diversas; desde motivação à conservação do meio ambiente até o cumprimento da legislação.

Enfim, caso o produtor manifeste interesse tem-se o início do fomento. Segundo Kageyama \& CESP (1992, p. 34), a partir desse momento, técnicos da empresa visitam a propriedade para reconhecimento da área e avaliação dos recursos disponíveis para implantação do projeto. Segue-se então a elaboração de um ante-projeto - constando as facilidades existentes na propriedade - e o projeto executivo. Posteriormente, é elaborado o "Instrumento Particular de Contrato de Cooperação Recíproca para Implantação de Projeto de Reflorestamento Ciliar". Na tabela 10 tem-se o resultado obtido pela CESP através de suas atividades de fomento florestal.

Adicionando os valores das tabelas 9 e 10 para o período de 1995 a 1998 constata-se que a CESP conseguiu a média anual de reposição de 1.524 ha. Para efeito de comparação, o PRÓ-FLORESTA em Minas Gerais reflorestou a média anual de 1.375 ha de matas ciliares no mesmo período (observe a tabela 4).

Tabela 10 - Atividades realizadas com o fomento florestal pela CESP.

\begin{tabular}{cccc}
\hline Período & Área contatada (ha) & Mudas contratadas (unidade) & $\mathrm{N}^{\circ}$ de contratos \\
\hline 1988 a 1994 & $1.633,52$ & 3.490 .373 & 275 \\
1995 & 850,09 & 1.579 .184 & 192 \\
1996 & 717,71 & 1.316 .034 & 186 \\
1997 & 908,70 & 1.687 .275 & 334 \\
1998 & 993,07 & 1.722 .895 & 396 \\
\hline Total & $5.103,09$ & 9.795 .761 & 1.383
\end{tabular}

Fonte: CESP (1999)

Para implantação das florestas através da CESP são produzidas mudas de 170 espécies florestais nativas. A empresa contava até 1998 com 5 viveiros com capacidade para produção total de 5.700 .000 mudas/ano. No entanto, a produção anual de mudas tem ficado abaixo da capacidade instalada (observe a tabela 11). 
Tabela 11 - Produção de mudas (unidade), por viveiro, pela CESP.

\begin{tabular}{ccccccc}
\hline \multirow{5}{*}{ Anos } & \multicolumn{5}{c}{ VIVEIROS } & \multirow{2}{*}{ Total } \\
\cline { 2 - 6 } & Paraibuna & Jupián & Ilha Solteira & $\begin{array}{c}\text { Porto } \\
\text { Primavera }\end{array}$ & Promissão & \\
\hline 1994 & 616.066 & 1.195 .496 & 579.221 & 346.971 & 294.172 & 3.031 .926 \\
1995 & 657.224 & 385.263 & 489.903 & 504.157 & 310.916 & 2.347 .463 \\
1996 & 1.476 .923 & 807.551 & 707.399 & 288.653 & 381.171 & 3.661 .697 \\
1997 & 1.220 .000 & $2.016 .915^{*}$ & 981.096 & 662.053 & 4.880 .064 \\
1998 & 1.087 .913 & $1.649 .626^{*}$ & 800.200 & 602.266 & 4.140 .005 \\
\hline
\end{tabular}

Fonte: CESP (1999)

* A partir de 1997, os viveiros de Ilha Solteira e Jupiá passaram a produzir em conjunto

Segundo CESP (1993, p. 325) os reflorestamentos da empresa em seu início baseavam-se no modelo de plantio com distribuição ao acaso das espécies. Essa metodologia acarretava um longo tempo para estabelecimento da floresta e o insucesso de diversas espécies. Dessa maneira, buscando o aprimoramento da tecnologia de recomposição florestal até então vigente, a CESP firmou um convênio de cooperação com a ESALQ/IPEF.

O atual modelo empregado na recomposição vegetal é o da sucessão secundária induzida. Assim, são utilizadas na recomposição espécies vegetais pertencentes a estágios sucessionais distintos (CESP, 1999).

De acordo com Ferretti (2000, p. 26), operacionalmente, grupos de espécies com exigências complementares, principalmente quanto à necessidade de luz, são associados de tal forma que as espécies de estágios iniciais (pioneiras) sejam sombreadoras das espécies de estágios finais (secundárias e clímax), recobrindo rapidamente a área, tutorando o crescimento, debilitando as gramíneas, promovendo o intercâmbio de sementes, etc. Para tanto, cada espécie de crescimento lento é circundada por quatro indivíduos de espécies de crescimento rápido, ocupando posição central em relação a estas. Como os grupos possuem exigências complementares, principalmente quanto à necessidade de luz, isso proporciona condições de sombra na fase inicial àquelas espécies de crescimento lento. 
Segundo CESP (1999, p. 04), com a adoção do modelo de sucessão secundária induzida o prazo para consolidação definitiva do plantio foi reduzido para 18 meses. Anteriormente ele variava de três a cinco anos. Além disso, os custos operacionais de implantação e manutenção foram reduzidos em função, principalmente, do menor número necessário de capinas na consolidação do plantio. Até o final da década de 80 , os custos de implantação e manutenção da floresta eram em média de $R \$ 4.500,00 /$ ha e passaram, atualmente, no caso de implantação com recursos próprios a $\mathbf{R} \$ 1.500,00 / \mathrm{ha}$ e a $R \$ 750,00 /$ ha nos casos de fomento florestal.

\subsubsection{Reflorestamento realizado pelo setor de papel e celulose em São Paulo}

A indústria de celulose e papel necessita de grande quantidade de matéria-prima florestal devido a sua escala de produção. No Estado de São Paulo, o setor de celulose e papel é extremamente atuante. Segundo a BRACELPA (1998), São Paulo foi responsável por $36,39 \%$ da produção brasileira de celulose de fibra curta no ano de 1998. Neste mesmo ano, o Estado produziu 3.015.679 toneladas de papel, o que representa $45,77 \%$ da produção brasileira.

Os reflorestamentos promovidos pelo setor de papel e celulose através de fomento florestal no Estado também são bastante significativos (observe a tabela 12).

Tabela 12 - Resultados dos programas de fomento florestal do setor de papel e celulose no Estado de São Paulo.

\begin{tabular}{ccc}
\hline Período & Mudas doadas (mil) & Área Reflorestada (ha) $^{*}$ \\
\hline 1991 & 7.008 & $3.047,0$ \\
1992 & 10.770 & $4.682,6$ \\
1993 & 10.629 & $4.621,3$ \\
1994 & 9.084 & $3.949,6$ \\
1995 & 7.752 & $3.370,4$ \\
1996 & 8.828 & $3.838,3$ \\
1997 & 6.091 & $2.648,3$ \\
1998 & 6.435 & $2.797,8$ \\
\hline
\end{tabular}

Fonte: elaborado a partir de dados da Bracelpa (1998)

* considerou-se para cálculo da área reflorestada que 2.300 mudas foram utilizadas para plantio de 1 hectare 


\subsection{Programas públicos e privados de fomento florestal no Estado do Paraná}

O Estado do Paraná, de modo similar ao de Minas Gerais, chama ao órgão responsável pela política florestal (no caso o Instituto Ambiental do Paraná) o direito de recolher a taxa de reposição florestal dos pequenos consumidores de matéria-prima florestal. Esses recursos e outros orçamentários foram e continuam sendo utilizados para financiar as atividades do IAP entre as quais está a promoção do fomento florestal no Estado (como será examinado no subitem 2.4.1). De outro lado, de modo similar ao Estado de São Paulo os programas privados de fomento florestal no Paraná são conduzidos, principalmente, pelo setor de papel e celulose (tópico analisado no subitem 2.4.2).

\subsubsection{Programas públicos estaduais no Paraná}

Após o término do REPEMIR, no início da década de 80, o Governo do Estado do Paraná, visando incentivar o reflorestamento em pequenas e médias propriedades, promoveu a distribuição de mudas florestais e concedeu assistência técnica aos produtores rurais. Em geral, essas atividades eram sub-projetos de programas mais amplos. Esses sub-projetos faziam parte do "Programa de Desenvolvimento do Oeste do Paraná" (PRODOPAR), do "Programa Especial de Controle da Erosão dos Solos no Noroeste do Paraná" (PRONOROESTE) e do "Programa de Apoio Integrado ao Pequeno Produtor Rural" (PRÓ-RURAL). Além desses, o governo lançou, em 1983, o "Programa de Manejo Integrado do Solo e da Água" (PMISA), do qual um dos componentes era o reflorestamento de matas ciliares para fins de conservação e o plantio de florestas produtivas nas propriedades rurais.

Entre os anos de 1987 e 1996, o Estado do Paraná executou o "Programa ParanáRural" e, entre os anos de 1988 e 1996 o "Programa de Desenvolvimento Florestal Integrado" - PDFI.

Segundo Martin (1996, p. 243), o "Paraná-Rural" visava reverter o nível crítico de degradação ambiental causada por erosão hídrica em uma vasta área do Estado. A erosão hídrica do solo vem sendo considerada, desde o seu diagnóstico nos anos 70 , um 
dos principais problemas da agricultura paranaense. As causas apontadas para a erosão hídrica do solo são os métodos de manejo e conservação inadequados adotados pelos agricultores, a divisão fundiária adotada no Estado e a forma como foram implantadas as estradas rurais estaduais e municipais. De uma maneira em geral, a erosão hídrica afeta a viabilidade econômica das propriedades rurais já que implica degradação do solo, perdas de insumos e consequente queda na produtividade agrícola.

Diante desse cenário, definiu-se o "Subprograma de Manejo e Conservação do Solo" que era uma estratégia técnica centrada no uso de práticas que visassem o aumento da cobertura do solo e da infiltração de água no seu perfil, o controle do escorrimento superficial da água e o controle da poluição.

"O objetivo principal do Subprograma de Manejo e Conservação do Solo era atacar as causas da erosão e não os seus efeitos, integrando as propriedades rurais dentro de uma área que concentra toda a água da chuva em uma linha de drenagem denominada microbacia hidrográfica ${ }^{12}$. Ao mesmo tempo, procurava integrar as propriedades, as estradas e os carreadores, envolvendo toda a comunidade, o município e os órgãos públicos que atuam na área agrícola e ambiental em nível local" (Martin, 1996, p. 247).

Para o desenvolvimento florestal foi estabelecido a distribuição de sementes e mudas necessárias ao plantio de 15.000 hectares de florestas conservacionistas e econômicas. Os recursos alocados para o desenvolvimento florestal totalizaram US\$ 14,91 mil, o que representou $10 \%$ dos recursos destinados ao subprograma como um todo.

Em 1991 foi lançado pelo IAP o "Projeto Água Limpa" que consistia na conservação e recomposição das matas ciliares em mananciais de abastecimento público. Segundo Martim (1996), o "Projeto Água Limpa" foi um programa complementar ao Programa Paraná-Rural.

\footnotetext{
${ }^{12}$ Conceitua-se microbacia hidrográfica como uma área compreendida entre um fundo de vale (rio, riacho, sanga e várzeas) e os espigões (divisões de água) que delimitam os pontos dos quais toda a água das chuvas escorre para esse fundo de vale.
} 
Bacha (1998) constatou que o Projeto Água Limpa, desde 1997, tornou-se apenas uma "marca" a título de marketing ecológico. As ações de distribuição de mudas, visando a recuperação de matas ciliares protetoras de mananciais de água, passaram a ser computadas no PRODEFLOR e no "Programa Florestas Municipais" mas divulgadas sob o nome do "Projeto Água Limpa".

O "Programa de Desenvolvimento Florestal Integrado" (PDFI), assim como o "Paraná-Rural", promovia a doação (no caso das essências exóticas) ou venda (no caso das essências nativas) de mudas a preço de custo aos produtores rurais. $\mathrm{O}$ Estado concedia ainda a prestação de assistência técnica gratuita. Diferentemente do "ParanáRural", o PDFI era financiado com recursos do Tesouro Estadual, o que justificava a não união dos dois em um único programa.

Outros dois programas de fomento ao reflorestamento foram lançados no ano de 1997, pelo Governo do Estado do Paraná. São eles: o "Programa Estadual de Desenvolvimento Florestal" - PRODEFLOR e o "Programa Florestas Municipais".

Segundo Paraná (1998, p. 10), o objetivo do PRODEFLOR é aproveitar a disposição do serviço público estadual - IAP (Instituto Ambiental do Paraná) e EMATER-PR (Empresa de Assistência Técnica e Extensão Rural), para dar continuidade a recuperação florestal no Estado, através, principalmente, do incentivo a reflorestamentos produtivos e conservacionistas. Assim, o programa tem como metas globais o treinamento e capacitação de técnicos e viveiristas; a coleta, beneficiamento e armazenamento de sementes florestais; a difusão de tecnologias e a extensão florestal. Segundo Bacha (1998), no ano de 1997 as mudas de nativas foram doadas e as de exóticas foram vendidas a preços de mercado. A partir de 1998, ambos os tipos de mudas passaram a ser vendidas.

O "Programa Florestas Municipais", através do envolvimento de prefeituras, busca delegar às populações urbana e rural as atividades ligadas ao desenvolvimento e conservação ambiental. Os objetivos principais do programa são o reflorestamento para produção e para conservação, a arborização urbana e rodoviária, e a promoção da educação ambiental. Através de convênios com municípios, o governo do Estado 
promove o repasse de sementes, insumos e defensivos para a produção de mudas nos viveiros florestais municipais. Oferece treinamento para técnicos e cede, em regime de comodato, veículos para a realização de tarefas pertinentes ao fomento florestal. $O$ período de vigência estipulado para o programa é de 4 anos e a meta é o plantio de 20 milhões de mudas de árvores por ano (APROMAC, 1998).

Os resultados dos programas estaduais de fomento ao reflorestamento no Estado do Paraná, entre os anos de 1979 e 1999, são apresentados na tabela 13. Observa-se um aumento na quantidade de mudas distribuídas para florestas para produção entre $1980 \mathrm{e}$ 1982, justificado pela realização do REPEMIR no Paraná. A partir de 1983 tem início um decréscimo na distribuição de mudas o qual só é interrompido em 1988. Isto porque são implantados o PDFI (1987) e Paraná-Rural (1988). Note que até 1989 houve aumento na quantidade de mudas distribuídas nos dois programas, porém, seguido por acentuado decréscimo entre os anos de 1990 e 1991. Isso se estende até o ano de 1996.

Em 1997, com a implantação do PRODEFLOR e do "Programa Florestas Municipais", houve um aumento na quantidade de mudas distribuídas para fins de produção. No que diz respeito às quantidades de mudas distribuídas para fins de conservação observa-se, de maneira em geral, o mesmo comportamento. Apenas em dois períodos específicos existem divergências. Entre 1983 e 1986 enquanto o número de mudas exóticas distribuídas diminui, o número de mudas nativas aumenta. Isso é justificado principalmente pela atuação do PMISA, que foi lançado em 1983 e cujo um dos componentes era o reflorestado de matas ciliares com fins de conservação. Entre 1996 e 1997 enquanto o número de mudas exóticas distribuídas aumenta significativamente, o número de mudas nativas diminui. A justificativa para isto está em dificuldades incorridas com a demissão de 200 viveiristas contratados por tempo determinado por exigência do Tribunal de Contas. Isso significou a subtração de $65 \%$ da força de trabalho nos viveiros florestais do IAP (Paraná, 1998). 
Tabela 13 - Destinação de mudas florestais (unidade) e área reflorestada (hectares) anualmente pelos programas oficiais de fomento florestal no Paraná.

\begin{tabular}{ccccccc} 
& \multicolumn{2}{c}{ Florestas para a produção } & \multicolumn{2}{c}{ Florestas para a conservação } & Total de \\
Anos & $\begin{array}{c}\text { Mudas } \\
\text { distribuídas }\end{array}$ & $\begin{array}{c}\text { Área } \\
\text { reflorestada* }\end{array}$ & $\begin{array}{c}\text { Mudas } \\
\text { distribuídas }\end{array}$ & $\begin{array}{c}\text { Total de áreas } \\
\text { reflorestada* }\end{array}$ & $\begin{array}{c}\text { Áflorestadas } \\
\text { distribuídas }\end{array}$ & \\
\hline 1979 & 2.272 .700 & $\mathbf{9 8 8 , 1 3}$ & 1.786 .000 & 776,52 & 4.058 .700 & $1.764,65$ \\
1980 & 4.388 .700 & $1.908,13$ & 3.448 .300 & $1.499,26$ & 7.837 .000 & $5.172,04$ \\
1981 & 8.289 .100 & $3.603,96$ & 6.512 .900 & 2831,70 & 14.802 .000 & $6.435,66$ \\
1982 & 10.507 .053 & $4.568,28$ & 7.004 .702 & $3.045,52$ & 17.511 .755 & $7.613,80$ \\
1983 & 8.903 .950 & $3.871,28$ & 5.935 .967 & $2.580,86$ & 14.839 .917 & $6.452,14$ \\
1984 & 8.281 .444 & $3.600,63$ & 6.775 .728 & $2.945,97$ & 15.057 .172 & $6.546,60$ \\
1985 & 8.655 .300 & $3.763,17$ & 10.578 .700 & $4.599,43$ & 19.234 .000 & $8.362,60$ \\
1986 & 7.303 .707 & $3.175,52$ & 7.017 .289 & $3.051,00$ & 14.320 .996 & $6.226,52$ \\
1987 & 3.850 .000 & $1.673,91$ & 3.150 .000 & $1.369,57$ & 7.000 .000 & $3.043,48$ \\
1988 & 14.780 .000 & $6.426,09$ & 10.720 .000 & $4.660,87$ & 25.500 .000 & $11.086,96$ \\
1989 & 22.900 .000 & $9.956,52$ & 16.600 .000 & $7.217,39$ & 39.500 .000 & $17.173,91$ \\
1990 & 14.646 .000 & $6.367,83$ & 9.061 .800 & $3.939,91$ & 23.707 .800 & $10.307,74$ \\
1991 & 8.602 .683 & $3.740,30$ & 5.933 .171 & $2.579,64$ & 14.535 .854 & $6.319,94$ \\
1992 & 9.124 .032 & $3.966,97$ & 8.473 .180 & $3.683,99$ & 17.597 .212 & $7.650,96$ \\
1993 & 9.354 .389 & $4.067,13$ & 8.179 .158 & $3.556,16$ & 17.533 .547 & $7.623,29$ \\
1994 & 7.850 .151 & $3.413,11$ & 6.971 .897 & $3.031,26$ & 14.822 .048 & $6.444,37$ \\
1995 & 6.639 .187 & $2.886,60$ & 6.602 .770 & $2.870,77$ & 13.241 .957 & $5.757,37$ \\
1996 & 6.523 .365 & $2.836,25$ & 6.386 .617 & $2.776,79$ & 12.909 .982 & $5.613,04$ \\
1997 & 11.850 .914 & $5.152,57$ & 4.992 .795 & $2.170,78$ & 16.843 .709 & $7.323,35$ \\
1998 & 21.540 .463 & $9.365,42$ & 7.575 .760 & $3.293,81$ & 29.116 .223 & $12.659,23$ \\
1999 & 24.673 .383 & $10.727,58$ & 10.858 .107 & $4.720,92$ & 35.531 .490 & $15.448,50$ \\
\hline Total & 220.936 .551 & $96.059,38$ & 154.564 .841 & $67.202,12$ & 375.501 .362 & $165.026,15$ \\
\hline
\end{tabular}

Fonte: elaborado a partir de dados do IAP (2000)

* Considerou-se para cálculo da área reflorestada 2.300 mudas para 1 hectare, conforme padrão adotado pelo IAP para o ano de 1999

Existem resultados expressivos com os programas de distribuição e vendas de mudas no Estado do Paraná, considerando-se que são utilizadas 2.300 mudas para cada hectare (padrão adotado pelo IAP para o ano 2000). No entanto, é possível que não ocorra a implantação de todas as mudas ou que, mesmo havendo o plantio, estas não tenham atingido com sucesso a maturação. O IAP não tem informações sobre este aspecto visto que não realiza o monitoramento das áreas fomentadas.

\subsubsection{Programas privados de fomento florestal no Paraná}

O setor de papel e celulose realiza o reflorestamento de áreas no Estado do Paraná através de fomento florestal. São florestas para produção que visam suprir parte das necessidades de matéria-prima florestal destas empresas. Entretanto, os resultados 
alcançados não são tão significativos como os obtidos, por exemplo, em São Paulo (compare os resultados das tabelas 12 e 14).

Tabela 14 - Resultados dos programas de fomento florestal do setor de papel e celulose no Estado do Paraná.

\begin{tabular}{ccc}
\hline Período & Mudas doadas (mil) & Área Reflorestada (ha) \\
\hline 1991 & 1.001 & 435,2 \\
1992 & 3.764 & $1.636,5$ \\
1993 & 3.166 & $1.376,5$ \\
1994 & 2.579 & $1.121,3$ \\
1995 & 2.747 & $1.194,3$ \\
1996 & 2.171 & 943,9 \\
1997 & 2.422 & 2.422 \\
1998 & 1.894 & 1.894 \\
\hline
\end{tabular}

Fonte: elaborado a partir de dados da Bracelpa (1998)

*considerou-se para cálculo da área reflorestada 2.300 mudas para 1 hectare

\subsection{Comparação das políticas florestais implementadas em Minas Gerais, São} Paulo e Paraná

Averiguou-se a existência de diferenças marcantes nas políticas florestais implementadas nos três Estados, sintetizadas no quadro 2. A principal delas refere-se a existência de uma lei florestal estadual em Minas Gerais e Paraná e a não existência da mesma no Estado de São Paulo. A este fato está intimamente relacionada a orientação das políticas florestais e a forma de operacionalização dos órgãos responsáveis pela questão florestal em cada um dos estados.

Observou-se três casos distintos na condução da política estadual de fomento florestal. De um lado tem-se o Estado de São Paulo que fundamentou a política de estímulo ao reflorestamento em pequenos e médios imóveis rurais em organizações civis e na iniciativa privada. Assim, em São Paulo a atividade é promovida, principalmente, por empresas do setor de papel e celulose (florestas de produção) e pela CESP (plantio de matas ciliares).

Contrariamente, tem-se o Estado do Paraná que centralizou as atividades voltadas à promoção do reflorestamento em pequenos e médios imóveis rurais no governo estadual. A operacionalidade das questões florestais é desenvolvida pelo Instituto 
Ambiental do Paraná que envolve diversos agentes no processo de reposição florestal, dentre eles, prefeituras municipais e produtores rurais.

Em Minas Gerais observa-se uma situação intermediária aos dois outros estados, que tanto envolve o poder público quanto a iniciativa privada no fomento florestal. $O$ governo estadual estimula o reflorestamento através de programas junto a pequenos e médios imóveis rurais. Da mesma forma, ocorrem programas de caráter privado com o mesmo objetivo. Em geral, são empresas do setor siderúrgico a carvão vegetal que estimulam o reflorestamento em pequenos e médios imóveis rurais em Minas Gerais. 


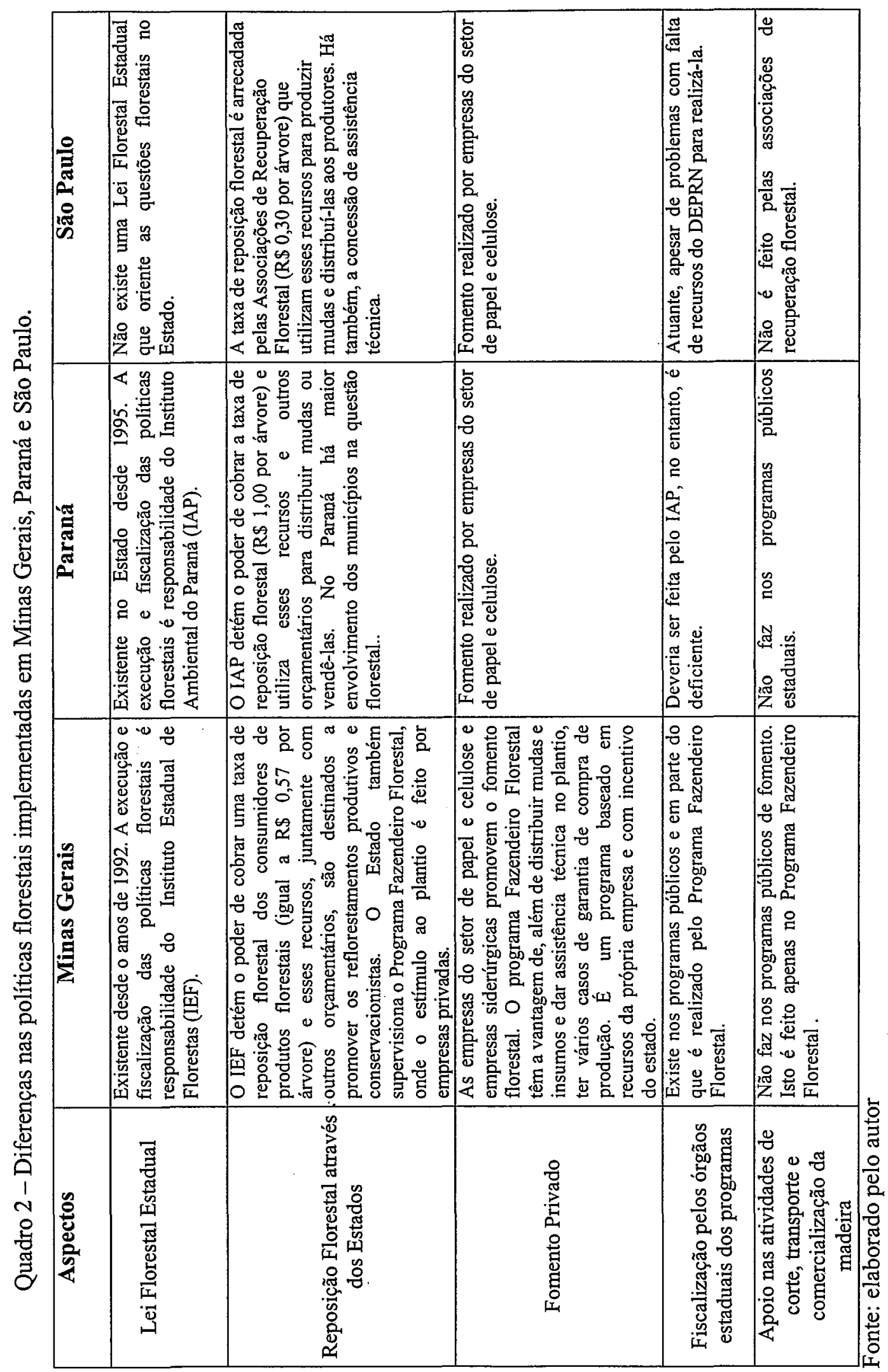



PAULO E PARANÁ

Este capítulo analisa a evolução do reflorestamento em Minas Gerais, São Paulo e Paraná, ressaltando a importância dos diferentes programas mencionados no capítulo anterior na determinação do ritmo e do estoque de reflorestamento em pequenos e médios imóveis rurais.

Inicialmente, é necessário distinguir dois termos: "área reflorestada anualmente" e "área reflorestada em dado momento do tempo". O primeiro refere-se a área plantada anualmente. $\mathrm{O}$ segundo considera o que de fato existe em dado ano, o qual depende da área previamente existente, do que foi plantado no ano e o que deixou de ser área reflorestada por terem sido as árvores cortadas e a terra destinada a outro uso.

É possível que, mesmo com o aumento, ao longo do tempo, do ritmo de reflorestamento proporcionado por certo tipo de programa (como o de fomento em pequenos e médios imóveis rurais) o estoque de área reflorestada diminua. Isto ocorre porque os cortes de florestas e a reversão do uso da terra estão sendo maiores do que os plantios. Esta situação indicaria, por exemplo, insuficiência de ritmo de plantio nos programas estabelecidos.

\subsection{Evolução da área reflorestada anualmente em pequenos e médios imóveis rurais no Estado de Minas Gerais}

No Estado de Minas Gerais, os programas estaduais que contribuíram com maior representatividade, em termos de área reflorestada, foram o PRODEMATA (período de 1976 a 1983) e o PRÓ-FLORESTA (período de 1989 a 1996). Os resultados alcançados com os programas estaduais de incentivo à atividade junto a pequenos e médios imóveis 
rurais na década de 90 são bastante significativos. Até 1989 , havia sido reflorestado $28,30 \%$ do total reflorestado através de programas estaduais (observe a tabela 15). Os restantes $71,70 \%$ foram obtidos através de programas estaduais implementados na década de 90 .

Também na década de 90, o Programa Fazendeiro Florestal tornou-se uma importante alternativa à promoção do reflorestamento em pequenos e médios imóveis rurais no Estado. No período de 1990 a 1998, foram plantados, em média, 9.035,02 hectares por ano de florestas por meio dos programas estaduais. No mesmo período, o Programa Fazendeiro Florestal plantou, em média, 8.391,67 hectares por ano de florestas produtivas.

Tabela 15 - Área reflorestada (em ha) anualmente em Minas Gerais nos pequenos e médios imóveis rurais, segundo alguns segmentos'.

\begin{tabular}{ccccc}
\hline Anos & $\begin{array}{c}\text { Programas } \\
\text { Estaduais }\end{array}$ & $\begin{array}{c}\text { Programas privados em } \\
\text { parceria com o IEF }\end{array}$ & "Fazendeiro Florestal" & Sub-Total \\
\hline 1976 & $3.257,94$ & - & & \\
1977 & $3.257,94$ & - & - & $3.257,94$ \\
1978 & $3.257,94$ & - & - & $3.257,94$ \\
1979 & $3.257,94$ & - & - & $3.257,94$ \\
1980 & $4.933,94$ & $2.491,50$ & - & $3.257,94$ \\
1981 & $5.934,44$ & $2.491,50$ & - & $4.933,94$ \\
1982 & $5.934,44$ & - & - & $8.425,94$ \\
1983 & $4.933,94$ & - & - & $8.425,94$ \\
1984 & 0 & $5.663,5$ & - & $4.933,94$ \\
1985 & 0 & $5.270,83$ & - & 0 \\
1986 & 0 & $1.014,33$ & $4.583^{3}$ & $5.663,5$ \\
1987 & 0 & $1.014,33$ & 3.374 & $5.270,83$ \\
1988 & 0 & - & 9.989 & $5.597,33$ \\
1989 & 0 & - & 12.378 & $4.388,33$ \\
1990 & 5.295 & - & 7.976 & 9.989 \\
1991 & $9.584,5$ & - & 13.244 & 17.673 \\
1992 & 8.181 & - & 7.564 & $17.560,5$ \\
1993 & 11.469 & - & 6.502 & 21,425 \\
1994 & $12.349,5$ & - & 6.323 & 19.033 \\
1995 & $11.022,5$ & - & 5.831 & $18.455,5$ \\
1996 & 14.026 & - & 6.536 & $17.345,5$ \\
1997 & $2.927,7$ & - & 9.171 & 19.857 \\
1998 & $6.855,98$ & n.d. & $9.463,7$ \\
1999 & $6.909,48$ & $0.026,98$ \\
\hline
\end{tabular}

Fonte: elaborado a partir de dados obtidos junto ao IEF; da ABRACAVE (1998) e IEF (2000).

${ }^{1}$ considerou-se que os plantios feitos através do Prodemata, MGII, Planoroeste e dos programas privados em parceria com o IEF foram de mesmo montante em cada ano em que foi executado tais programas

2 são os programas comentados no quadro 1

${ }^{3}$ corresponde ao total reflorestado até 1987 
Constata-se que a atuação conjunta entre governo estadual e iniciativa privada está gerando resultados satisfatórios no que diz respeito ao plantio anual de florestas em Minas Gerais. Observa-se, também, que a atuação do Governo Estadual, via programas públicos, vem contribuindo para a inclusão do pequeno e médio produtor rural no processo de reflorestamento do Estado.

\subsection{Evolução da área reflorestada anualmente em pequenos e médios imóveis rurais no Estado de São Paulo}

A maior participação no total de reflorestamentos realizados em pequenos $\mathrm{e}$ médios imóveis rurais no Estado é do fomento realizado pelo setor de papel e celulose de 1987 a 1998. Do total de áreas reflorestadas junto a pequenos e médios imóveis rurais em São Paulo, aproximadamente 50\% é proveniente do setor de papel e celulose (tabela 16).

Tabela 16 - Área reflorestada (em ha) anualmente em São Paulo em pequenos e médios rurais segundo alguns segmentos.

\begin{tabular}{lcccc}
\hline Anos & $\begin{array}{c}\text { Associações de } \\
\text { Recuperação } \\
\text { Florestal }\end{array}$ & CESP & $\begin{array}{c}\text { Plantio fomentado pelas } \\
\text { empresas }\end{array}$ & Sub- Total \\
\cline { 4 - 5 } & 135,00 & - & Papel/Celulose & \\
\hline 1987 & 355,07 & - & - & 135,00 \\
1988 & $1.158,84$ & - & - & 355,07 \\
1989 & 998,41 & - & - & $1.158,84$ \\
1990 & $1.920,52$ & - & $3.047,0$ & 998,41 \\
1991 & $1.835,95$ & - & $4.682,6$ & $4.967,52$ \\
1993 & $2.637,21$ & - & $4.621,3$ & $6.518,55$ \\
1994 & $2.804,30$ & $5.436,94^{*}$ & $3.949,6$ & $7.258,51$ \\
1995 & $2.788,97$ & 259,51 & $3.370,4$ & $12.190,84$ \\
1996 & $2.837,87$ & 447 & $3.838,3$ & $6.418,88$ \\
1997 & n.d. & 1103,20 & $2.648,3$ & $7.123,17$ \\
1998 & n.d. & 816,80 & $2.797,8$ & $3.751,5$ \\
\hline
\end{tabular}

Fonte: elaborado a partir de dados da CESP(1999) e BRACELPA (1998) e pesquisa junto a FARESP e Comissão de reposição Florestal do Estado de São Paulo.

* valores agregados equivalentes ao período de 1978 a 1994.

Observa-se que, no Estado de São Paulo, as empresas do setor de papel e celulose investem mais no fomento como alternativa para o aumento de oferta de matéria-prima florestal necessária às suas atividades. 
A ação das Associações de Recuperação Florestal é bastante significativa no processo de reflorestamento do Estado. Observa-se que o total de área reflorestada pelas ARFs no Estado de 1987 a 1996 representou 37,08\% do total reflorestado junto a pequenos e médios imóveis rurais.

O total de áreas reflorestadas pela CESP representou $13,04 \%$ do total de fomento realizado no Estado de 1987 a 1996. É um resultado bastante significativo e ainda mais valorizado quando se considera que são áreas reflorestadas com florestas de conservação (basicamente matas ciliares).

Constata-se que a falta de atuação direta do Governo Estadual no processo de reflorestamento junto às propriedades rurais em São Paulo explica o fato do reflorestamento anual ser menor do que o alcançado em Minas Gerais (compare as tabelas 15 e 16).

\subsection{Evolução da área reflorestada anualmente em pequenos e médios imóveis rurais no Estado do Paraná}

A área reflorestada anualmente em pequenos e médios imóveis rurais no Estado do Paraná apresenta aumentos significantes apenas nos anos em que são implantados programas estaduais. Nos anos de 1987 e 1988, por exemplo, foram lançados o PDFI e o Paraná-Rural; respectivamente. Isso repercutiu no aumento da área reflorestada por pequenos e médios imóveis rurais nos anos de 1988 e 1989 (observe a tabela 17). Da mesma forma, a partir de 1997, com a implantação do PRODEFLOR e do "Florestas Municipais", tem-se o aumento da área reflorestada anualmente.

O total de áreas fomentadas pelo setor de papel e celulose representou $16 \%$ do total de áreas reflorestadas no Estado junto a pequenos e médios imóveis rurais no período de 1991 a 1998. Por outro lado, os reflorestamentos realizados via programas estaduais representam cerca de $84 \%$ no mesmo período. 
Tabela 17 - Área reflorestada (em ha) anualmente no Paraná nos pequenos e médios imóveis rurais segundo alguns segmentos.

\begin{tabular}{cccc}
\hline & Programas Estaduais* & Fomento Privado & Sub-Total \\
\cline { 2 - 3 } Anos & & Papel/Celulose & \\
\hline 1979 & $1.764,65$ & - & $1.764,65$ \\
1980 & $5.172,04$ & - & $5.172,04$ \\
1981 & $6.435,66$ & - & $6.435,66$ \\
1982 & $7.613,80$ & - & $7.613,80$ \\
1983 & $6.452,14$ & - & $6.452,14$ \\
1984 & $6.546,60$ & - & $6.546,60$ \\
1985 & $8.362,60$ & - & $8.362,60$ \\
1986 & $6.226,52$ & - & $6.226,52$ \\
1987 & $3.043,48$ & - & $3.043,48$ \\
1988 & $11.086,96$ & - & $11.086,96$ \\
1989 & $17.173,91$ & - & $17.173,91$ \\
1990 & $10.307,74$ & - & $10.307,74$ \\
1991 & $6.319,94$ & 435,20 & $6.755,14$ \\
1992 & $7.650,96$ & $1.636,50$ & $9.287,46$ \\
1993 & $7.623,29$ & $1.376,50$ & $8.999,79$ \\
1994 & $6.444,37$ & $1.121,30$ & $7.565,67$ \\
1995 & $5.757,37$ & $1.194,30$ & $6.951,67$ \\
1996 & $5.613,04$ & 943,90 & $6.556,94$ \\
1997 & $7.323,35$ & $2.422,00$ & $9.745,35$ \\
1998 & $12.659,23$ & $1.894,00$ & $14.553,23$ \\
1999 & $15.448,50$ & n.d. & $15.448,50$ \\
\hline
\end{tabular}

Fonte: elaborada a partir de dados do IAP (2000); Paraná (1998) e BRACELPA (1998)

* Considerou-se que são utilizadas 2.300 mudas/ha (padrão adotado pelo IAP para o ano de 1999) e que o número de mudas distribuídas pelos programas oficiais de fomento florestal no Paraná é igual ao número de árvores efetivamente plantadas.

Observa-se assim uma grande centralização, pelo Governo Estadual, das atividades voltadas ao fomento florestal. Todavia, o objetivo de aumento das áreas reflorestadas no Paraná em pequenos e médios imóveis rurais está sendo alcançado (observe o tópico 3.6), embora a iniciativa privada esteja sendo pouco envolvida nesse processo.

\subsection{Evolução do estoque de área reflorestada em Minas Gerais}

De 1970 a 1985 houve aumento do estoque total de área reflorestada em Minas Gerais, seguida de redução entre 1985 e 1995 (observe a tabela 18). Este comportamento, porém, não foi idêntico entre os tipos de estabelecimentos rurais tanto no que diz respeito às diferentes finalidades quanto ao tamanho das propriedades rurais. 
Examinando a tabela 18, constata-se que no período de 1975 a 1995 houve aumento da área reflorestada existente nos pequenos e médios estabelecimentos rurais. Os grandes estabelecimentos elevaram a área reflorestada até 1985, diminuindo-a a partir de então.

Tabela 18 - Área ocupada com florestas plantadas, segundo o tamanho da propriedade rural, no Estado de Minas Gerais (em ha).

\begin{tabular}{llccccc}
\hline Categoria & \multicolumn{1}{c}{ Estrato (ha) } & $31 / 12 / 1970$ & $31 / 12 / 1975$ & $31 / 12 / 1980$ & $31 / 12 / 1985$ & $31 / 12 / 1995$ \\
\hline \multirow{6}{*}{ Pequenas } & Menos de 10 & 1.905 & 1.697 & 2.162 & 3.046 & 4.428 \\
& 10 a menos de 20 & 3.000 & 3.008 & 3.927 & 6.186 & 9.316 \\
& 20 a menos de 50 & 8.892 & 8.018 & 11.318 & 15.882 & 28.166 \\
& Total da categoria & $\mathbf{1 3 . 7 9 7}$ & $\mathbf{1 2 . 7 2 3}$ & $\mathbf{1 7 . 4 0 7}$ & $\mathbf{2 5 . 1 1 4}$ & 41.910 \\
& & & & & & \\
Médias & & & & & \\
& 50 a menos de 100 & 11.878 & 11.181 & 14.556 & 18.158 & 34.048 \\
& 100 a menos de 200 & 15.925 & 18.586 & 22.081 & 27.284 & 48.137 \\
& 200 a menos de 500 & 31.012 & 41.650 & 48.521 & 58.747 & 76.886 \\
& Total da categoria & $\mathbf{5 8 . 8 1 5}$ & $\mathbf{7 1 . 4 1 7}$ & $\mathbf{8 5 . 1 5 8}$ & $\mathbf{1 0 4 . 1 8 9}$ & $\mathbf{1 5 9 . 0 7 1}$ \\
& & & & & & \\
& 500 a menos de 1.000 & 23.660 & 47.207 & 57.110 & 61.997 & 70.889 \\
& 1000 a menos de 2000 & 26.331 & 62.690 & 84.840 & 117.596 & 87.750 \\
Grandes & 2000 a menos de 5000 & 65.016 & 126.365 & 287.468 & 303.677 & 197.274 \\
& 5000 a menos de 10000 & 38.843 & 129.300 & 199.448 & 276.659 & 301.106 \\
& 10.000 e mais & 45.059 & 138.227 & 853.958 & 878.625 & 849.784 \\
& sem declaração & - & - & - & - & - \\
& Total da categoria & $\mathbf{1 9 8 . 9 0 9}$ & $\mathbf{5 0 3 . 7 8 9}$ & $\mathbf{1 . 4 8 2 . 8 2 4}$ & $\mathbf{1 . 6 3 8 . 5 5 5}$ & $\mathbf{1 . 5 0 6 . 8 0 2}$ \\
\hline
\end{tabular}

Fonte: elaborado a partir de dados do Censo Agropecuário (vários números)

O aumento da área ocupada com florestas plantadas nos pequenos e médios imóveis rurais provavelmente é resultado dos programas públicos realizados no Estado que, somados aos programas privados de fomento florestal geraram resultados significativos. O aumento das áreas reflorestadas existentes nas pequenas e médias propriedades rurais entre 1985 e 1995, ao mesmo tempo em que ocorre redução nas grandes propriedades, indica a eficácia dos programas de fomento florestal direcionados àquelas propriedades.

As grandes propriedades apresentaram redução das áreas reflorestadas, seguindo o comportamento apresentado pelos estabelecimentos silvicultores nesse período. Os 
reflorestamentos próprios realizados pelos setores siderúrgicos e de papel e celulose estão vinculados a propriedades com maiores extensões de terra. Portanto, há indícios de que essa queda na área reflorestada seja reflexo do término dos incentivos fiscais, que beneficiaram em sua maioria os grandes projetos de reflorestamento. Também essa redução na área reflorestada pode ser justificada, em Minas Gerais, pelo fato da substituição do carvão vegetal (utilizado nas siderúrgicas como termo-redutor) pelo uso do coque mineral a partir de 1991. Isto ocorreu devido à queda do preço em dólar do coque mineral em conseqüência da valorização cambial da moeda nacional que ocorreu até 1996. No entanto, a maior parte do estoque de florestas plantadas ainda continua nas grandes propriedades (figura 1).

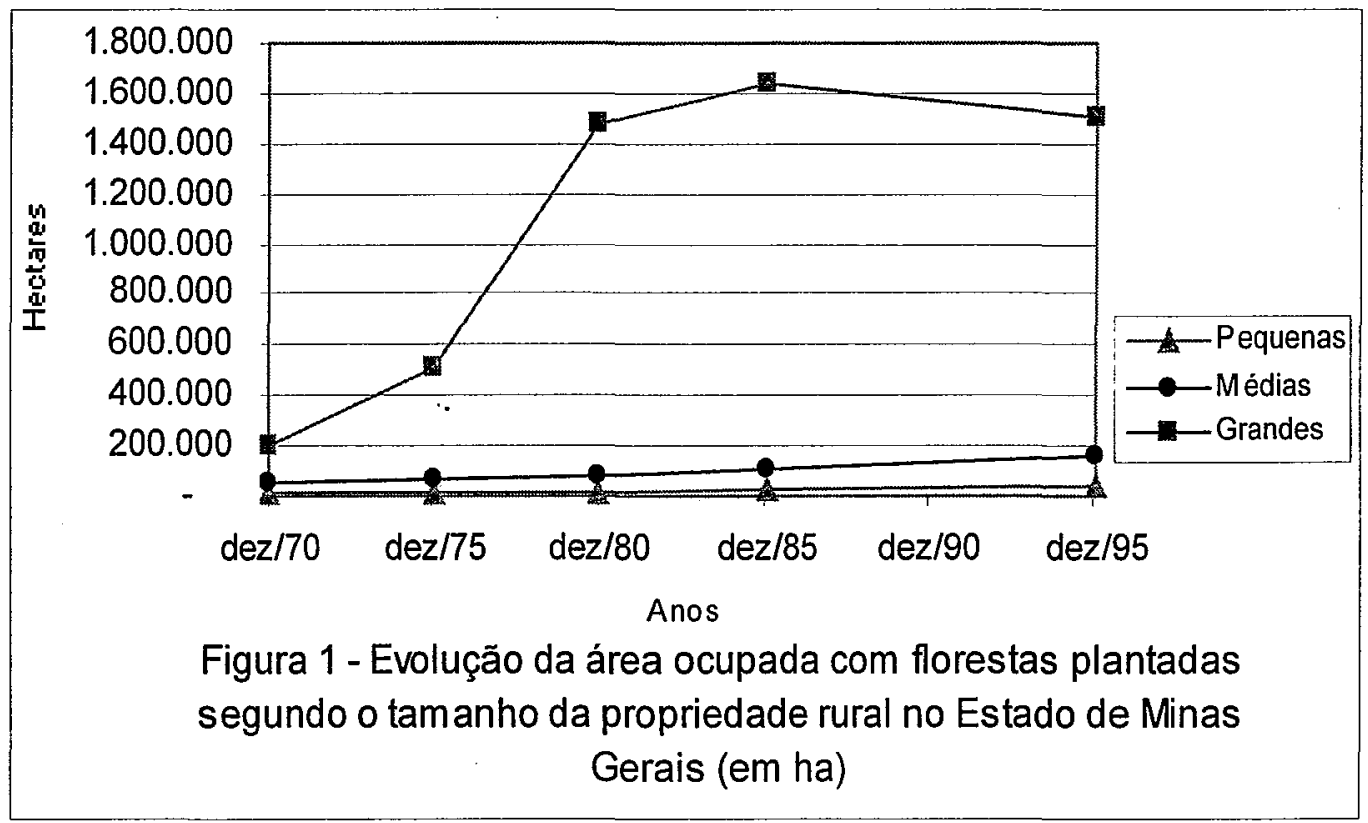

Fonte: elaborado a partir de dados do Censo Agropecuário (vários números)

Examinando a tabela 19 observa-se que a maioria dos estabelecimentos, segundo sua finalidade, expandiu continuamente sua área reflorestada, principalmente no período de 1970 a 1980. Entre os anos de 1980 e 1985, houve uma significativa redução das áreas ocupadas com florestas plantadas na maioria dos estabelecimentos. Apenas os estabelecimentos dedicados à horticultura e floricultura, à silvicultura e apicultura/cunicultura/sericicultura tiveram aumentos das áreas ocupadas com florestas plantadas. 
Tabela 19 - Área ocupada com florestas plantadas, segundo a atividade econômica principal, no Estado de Minas Gerais (em ha).

\begin{tabular}{|c|c|c|c|c|c|}
\hline $\begin{array}{l}\text { Utilização das } \\
\text { Terras / Ano }\end{array}$ & $31 / 12 / 70$ & $31 / 12 / 75$ & $31 / 12 / 80$ & $31 / 12 / 85$ & $31 / 12 / 95$ \\
\hline Agricultura & $27.370^{1}$ & 26.829 & 133.407 & 102.939 & 103.241 \\
\hline Pecuária & 33.354 & 43.297 & 277.098 & 104.822 & 155.797 \\
\hline Agropecuária & * & 4.653 & 24.346 & 9.644 & 48.180 \\
\hline $\begin{array}{l}\text { Horticultura e } \\
\text { Floricultura }\end{array}$ & 354 & 340 & 567 & 1.583 & 1.831 \\
\hline Silvicultura & 206.065 & . 504.066 & 1.051 .196 & 1.487 .114 & 755.305 \\
\hline Avicultura & 517 & 770 & 7.038 & 2.843 & * \\
\hline $\begin{array}{l}\text { Apicultura/ } \\
\text { Cunicultura / } \\
\text { Sericicultura }\end{array}$ & 2 & 5 & 55 & 270 & $*$ \\
\hline $\begin{array}{l}\text { Extração } \\
\text { Vegetal }\end{array}$ & 1.476 & 7.969 & 141.684 & 58.644 & $*$ \\
\hline Outros & $2.383^{2}$ & - & - & - & $643.429^{3}$ \\
\hline Total & 271.521 & 587.929 & 1.585 .391 & 1.767 .859 & 1.707 .783 \\
\hline
\end{tabular}

Fonte: Censo Agropecuário (vários números)

* Não disponível

${ }^{1}$ Refere-se à agricultura e agropecuária.

${ }^{2}$ Inclui invernadas, campo de engorda e finalidades especiais.

${ }^{3}$ Inclui pesca, aquicultura e produção de carvão vegetal.

Entre os anos de 1985 a 1995 somente as propriedades silvicultoras apresentaram redução da área reflorestada. ·As propriedades com agricultura, pecuária, agropecuária e horticultura/floricultura apresentaram crescimento do reflorestamento neste período. Isto está associado aos programas estaduais de incentivo ao reflorestamento em pequenos e médios imóveis rurais, analisados no capítulo 2. Esses programas procuram estimular o reflorestamento em propriedades cuja finalidade principal não é a silvicultura. 


\subsection{Evolução do estoque de área reflorestada em São Paulo}

De 1970 a 1985 houve aumento do estoque de área reflorestada em São Paulo seguida por redução entre 1985 e 1995. Este comportamento, no entanto, não foi igual entre os diversos tipos de estabelecimentos rurais. Segundo os dados da tabela 20, a área reflorestada existente em pequenos imóveis vem diminuindo desde 1970. De outro lado, os médios e grandes imóveis aumentaram o estoque de área reflorestada de 1970 a 1985 , diminuindo-a a partir de então.

Tabela 20 - Área ocupada com florestas plantadas segundo o tamanho da propriedade rural no Estado de São Paulo (em ha).

\begin{tabular}{llccccc}
\hline Categoria & \multicolumn{1}{c}{ Estrato (ha) } & $31 / 12 / 1970$ & $31 / 12 / 1975$ & $31 / 12 / 1980$ & $31 / 12 / 1985$ & $31 / 12 / 1995$ \\
& Menos de 10 & 6.624 & 5.001 & 4.670 & 4.904 & 3.806 \\
Pequenas & 10 a menos de 20 & 12.665 & 11.390 & 10.485 & 10.874 & 7.905 \\
& 20 a menos de 50 & 35.388 & 35.244 & 32.378 & 29.998 & 20.189 \\
& Total da categoria & $\mathbf{5 4 . 6 7 7}$ & $\mathbf{5 1 . 6 3 5}$ & 47.533 & $\mathbf{4 5 . 7 7 6}$ & $\mathbf{3 1 . 9 0 0}$ \\
& & & & & & \\
Médias & 50 a menos de 100 & 34.389 & 35.423 & 35.975 & 34.689 & 23.909 \\
& 100 a menos de 200 & 42.485 & 52.692 & 51.834 & 49.251 & 31.284 \\
& 200 a menos de 500 & 79.065 & 101.076 & 114.087 & 122.214 & 63.983 \\
& Total da categoria & $\mathbf{1 5 5 . 9 3 9}$ & $\mathbf{1 8 9 . 1 9 1}$ & $\mathbf{2 0 1 . 8 9 6}$ & $\mathbf{2 0 6 . 1 5 4}$ & $\mathbf{1 1 9 . 1 7 6}$ \\
& & & & & & \\
& 500 a menos de 1.000 & 83.216 & 112.861 & 142.575 & 137.138 & 83.745 \\
& 1000 a menos de 2000 & 88.608 & 141.135 & 154.311 & 175.055 & 70.961 \\
Grandes & 2000 a menos de 5000 & 101.056 & 184.179 & 161.618 & 193.889 & 112.465 \\
& 5000 a menos de 10000 & 41.751 & 90.648 & 94.837 & 104.982 & 88.475 \\
& 10.000 e mais & 52.190 & 75.035 & 63.056 & 49.733 & 90.278 \\
& sem declaração & - & - & - & - & - \\
& Total da categoria & $\mathbf{3 6 6 . 8 2 1}$ & $\mathbf{6 0 4 . 1 2 8}$ & $\mathbf{6 1 6 . 3 9 8}$ & $\mathbf{6 6 0 . 7 9 7}$ & $\mathbf{4 4 5 . 9 2 4}$ \\
\hline
\end{tabular}

Fonte: elaborado a partir de dados do Censo Agropecuário (vários números)

O grande aumento das áreas ocupadas com florestas plantadas nas grandes propriedades no primeiro qüinqüênio da década de 70 parece ser conseqüência do privilégio dado aos grandes projetos de reflorestamento pelo "Programa Florestal de São Paulo" "11, observe a figura 2.

\footnotetext{
11 Segundo Bergamasco \& Bergamasco o Programa Florestal de São Paulo tinha como respaldo os incentivos ficais consubstanciados na Lei Federal nำ 5106 (02/09/66). Esta Lei Federal criou os incentivos fiscais ao florestamento e reflorestamento, como já discutido no tópico 2.1 .
} 
De acordo com Bergamasco \& Bergamasco (1988) em São Paulo foi implantada uma área de 541.775,76 hectares de reflorestamentos por meio de incentivos fiscais até 1977. No Brasil este número chegou a 2.524.444 hectares. Em contrapartida, as pequenas e médias propriedades não conseguiam adequado acesso a este tipo de financiamento dada as restrições definidas no Programa de Incentivos Fiscais ao Florestamento e Reflorestamento.

No período de 1985 a 1995, tem-se que as pequenas, médias e grandes propriedades apresentaram redução das áreas reflorestadas (ver figura 2).

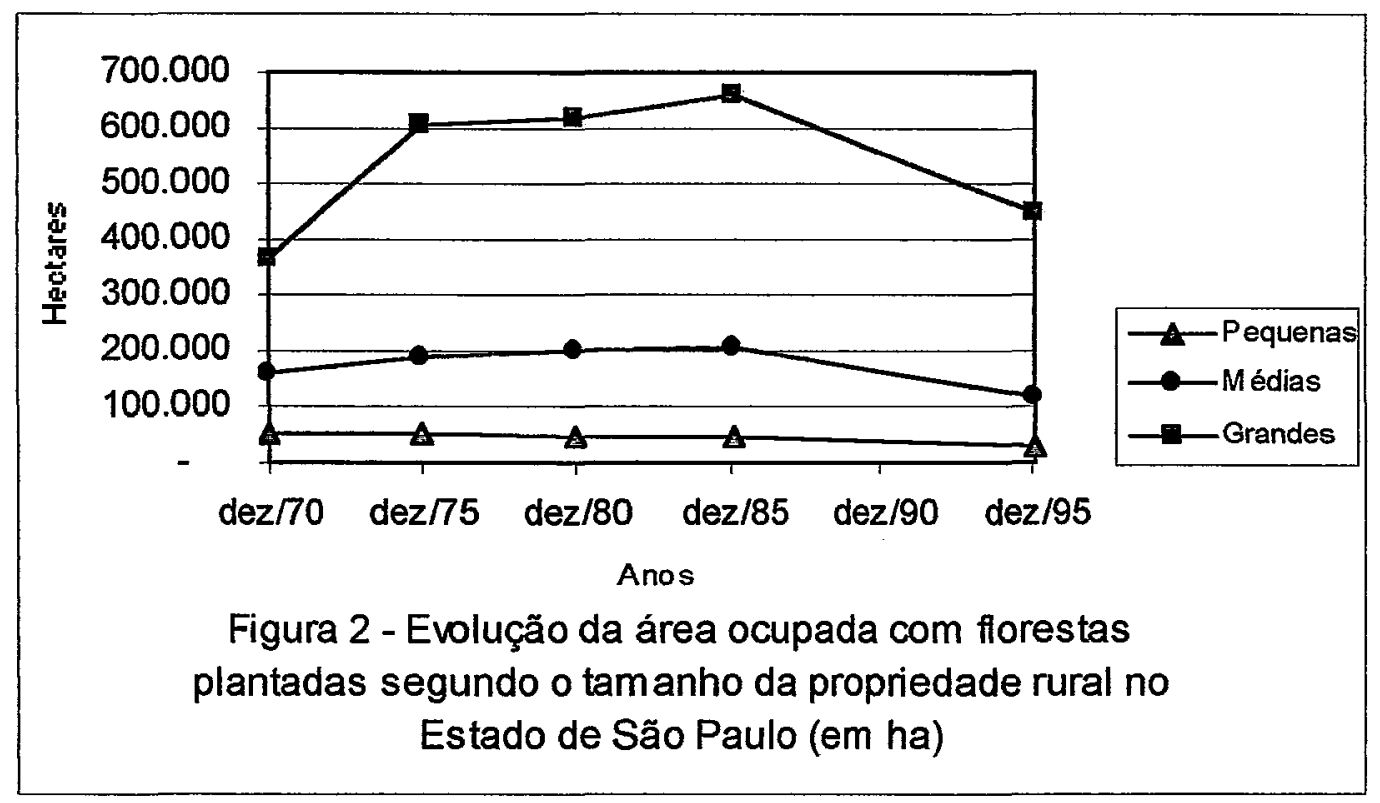

Fonte: elaborado a partir de dados do Censo Agropecuário (vários números)

No caso das pequenas e médias propriedades rurais este comportamento implica dizer que os programas de fomento florestal realizados pelas associações de recuperação florestal e pela CESP mostram-se ineficientes para manter a base florestal neste tipo de propriedade. A redução da base florestal nas grandes propriedades seguiu o comportamento apresentado pelos estabelecimentos silvicultores em todo o Brasil. Essa redução provavelmente está relacionada ao fim do programa federal de incentivos fiscais ao reflorestamento. 
Quando se analisa o comportamento da base florestal pelo tipo de atividade agrícola da propriedade observa-se comportamentos não coincidentes ao longo do tempo. Observe na tabela 21, onde são expostas as áreas com florestas no Estado de São Paulo de acordo com as finalidades econômicas dos estabelecimentos, que entre os anos de 1970 e 1975, houve aumento da área coberta com florestas plantadas em todos os estabelecimentos rurais.

Tabela 21 - Área ocupada com florestas plantadas, segundo a atividade econômica principal, no Estado de São Paulo (em ha).

\begin{tabular}{|c|c|c|c|c|c|}
\hline $\begin{array}{l}\text { Utilização das } \\
\text { Terras / Ano }\end{array}$ & $31 / 12 / 70$ & $31 / 12 / 75$ & $31 / 12 / 80$ & $31 / 12 / 85$ & $31 / 12 / 95$ \\
\hline Agricultura & $151.283^{1}$ & 125.994 & 139.399 & 127.921 & 52.364 \\
\hline Pecuária & 56.485 & 102.144 & 133.640 & 124.465 & 76.338 \\
\hline Agropecuária & * & 22.036 & 10.143 & 5.609 & 27.778 \\
\hline $\begin{array}{l}\text { Horticultura e } \\
\text { Floricultura }\end{array}$ & 1.229 & 1.974 & 2.017 & 2.011 & 3.640 \\
\hline Silvicultura & 320.100 & 583.090 & 567.902 & 640.078 & 430.124 \\
\hline Avicultura & 3.606 & 4.683 & 7.456 & 3.484 & * \\
\hline $\begin{array}{l}\text { Apicultura/ } \\
\text { Cunicultura / } \\
\text { Sericicultura }\end{array}$ & 578 & 686 & 625 & 2.014 & $*$ \\
\hline $\begin{array}{l}\text { Extração } \\
\text { Vegetal }\end{array}$ & 2545 & 4.347 & 4.646 & 7.144 & $*$ \\
\hline Outros & $41.611^{2}$ & - & - & - & $6.756^{3}$ \\
\hline Total & 577.437 & 844.954 & 865.828 & 912.726 & 597.000 \\
\hline
\end{tabular}

Fonte: Censo Agropecuário (vários números)

\footnotetext{
* Não disponível

${ }^{1}$ Refere-se à agricultura e agropecuária.

${ }^{2}$ Inclui invernadas, campos de engorda e finalidades especiais.

${ }^{3}$ Inclui pesca, aqüicultura e produção de carvão vegetal.
}

As taxas geométricas anuais de crescimento mais expressivas ocorreram nos estabelecimentos cujas atividades econômicas são a silvicultura, a pecuária e a extração vegetal, com $12,74 \%, 12,58 \%$ e $11,30 \%$, respectivamente. 
Entre os anos de 1975 e 1980 houve redução das áreas ocupadas com florestas plantadas nos estabelecimentos agropecuários, silviculturais e dedicados a apicultura/cunicultura/sericicultura. Por outro lado, houveram aqueles estabelecimentos que apresentaram aumento das áreas ocupadas com florestas plantadas. Merecem destaque os dedicados a avicultura e à pecuária.

Entre os anos de 1980 e 1985, houve aumento das áreas ocupadas com florestas plantadas apenas nos estabelecimentos dedicados a silvicultura, apicultura/cunicultura/sericicultura e extração vegetal. Nos demais estabelecimentos, houve a redução das áreas ocupadas com florestas plantadas, destacando-se aqueles dedicados a avicultura e agropecuária. A taxa geométrica anual de crescimento mais expressiva foi de $26,37 \%$ e ocorreu nos estabelecimentos dedicados a apicultura/cunicultura/sericicultura.

Entre os anos de 1985 e 1995 houve aumento das áreas ocupadas com florestas plantadas apenas nos estabelecimentos dedicados a agropecuária e a horticultura/floricultura. As taxas geométricas anuais de crescimento foram, respectivamente, $17,35 \%$ e $6,11 \%$. Nos demais estabelecimentos as áreas ocupadas com florestas plantadas diminuíram.

\subsection{Evolução do estoque de área reflorestada no Paraná}

De 1970 a 1985 houve aumento do estoque de área reflorestada no Paraná, seguida por redução entre 1985 e 1995. Entretanto, este comportamento não foi igual entre os diversos tipos de estabelecimentos rurais, seja no que diz respeito às finalidades econômicas ou ao tamanho dessas propriedades rurais.

Nota-se que em todo o período analisado (1970 a 1995) houve aumento da área reflorestada nos pequenos e médios estabelecimentos agropecuários (observe a tabela 22). Os grandes estabelecimentos elevaram a área reflorestada até 1985, diminuindo-a a partir de então (Figura 3). Esta última redução se explica pela mesma razão que explica o idêntico fenômeno ocorrido em Minas Gerais e São Paulo. 
Tabela 22 - Área ocupada com florestas plantadas, segundo o tamanho da propriedade rural, no Estado do Paraná (em ha).

\begin{tabular}{|c|c|c|c|c|c|c|}
\hline Categoria & Estrato (ha) & $31 / 12 / 1970$ & $31 / 12 / 1975$ & $31 / 12 / 1980$ & $31 / 12 / 1985$ & $31 / 12 / 1995$ \\
\hline \multirow{4}{*}{ Pequenas } & Menos de 10 & 2.285 & 2.299 & 3.520 & 6.346 & 6.847 \\
\hline & 10 a menos de 20 & 4.825 & 5.389 & 7.946 & 12.554 & 13.678 \\
\hline & 20 amenos de 50 & 11.514 & 13.320 & 19.781 & 27.887 & 29.947 \\
\hline & Total da categoria & 18.624 & 21.008 & 31.247 & 46.787 & 50.472 \\
\hline \multirow{4}{*}{ Médias } & 50 a menos de 100 & 8.274 & 10.891 & 17.011 & 22.373 & 25.934 \\
\hline & 100 a menos de 200 & 10.851 & 12.993 & 21.032 & 27.383 & 34.301 \\
\hline & 200 a menos de 500 & 23.228 & 24.702 & 50.022 & 67.210 & 75.141 \\
\hline & Total da categoria & 42.353 & 48.586 & 88.065 & 116.966 & 135.376 \\
\hline \multirow{7}{*}{ Grandes } & 500 a menos de 1.000 & 18.712 & 29.492 & 56.348 & 72.776 & 66.938 \\
\hline & 1000 a menos de 2000 & 20.935 & 43.777 & 79.806 & 106.002 & 95.589 \\
\hline & 2000 a menos de 5000 & 36.583 & 52.664 & 141.982 & 146.500 & 131.413 \\
\hline & 5000 a menos de 10000 & 26.011 & 75.068 & 79.415 & 82.130 & 66.592 \\
\hline & 10.000 e mais & 41.944 & 137.266 & 148.796 & 248.390 & 166.746 \\
\hline & sem declaração & - & - & - & - & - \\
\hline & Total da categoria & 144.186 & 338.267 & 506.347 & 655.798 & 527.278 \\
\hline
\end{tabular}

Fonte: elaborado a partir de dados do Censo Agropecuário (vários números)

O crescimento da área reflorestada existente nas pequenas e médias propriedades rurais a partir de 1980 explica-se, em grande parte, pelos programas estaduais de fomento florestal ocorridos no Estado e analisados no capítulo 2.

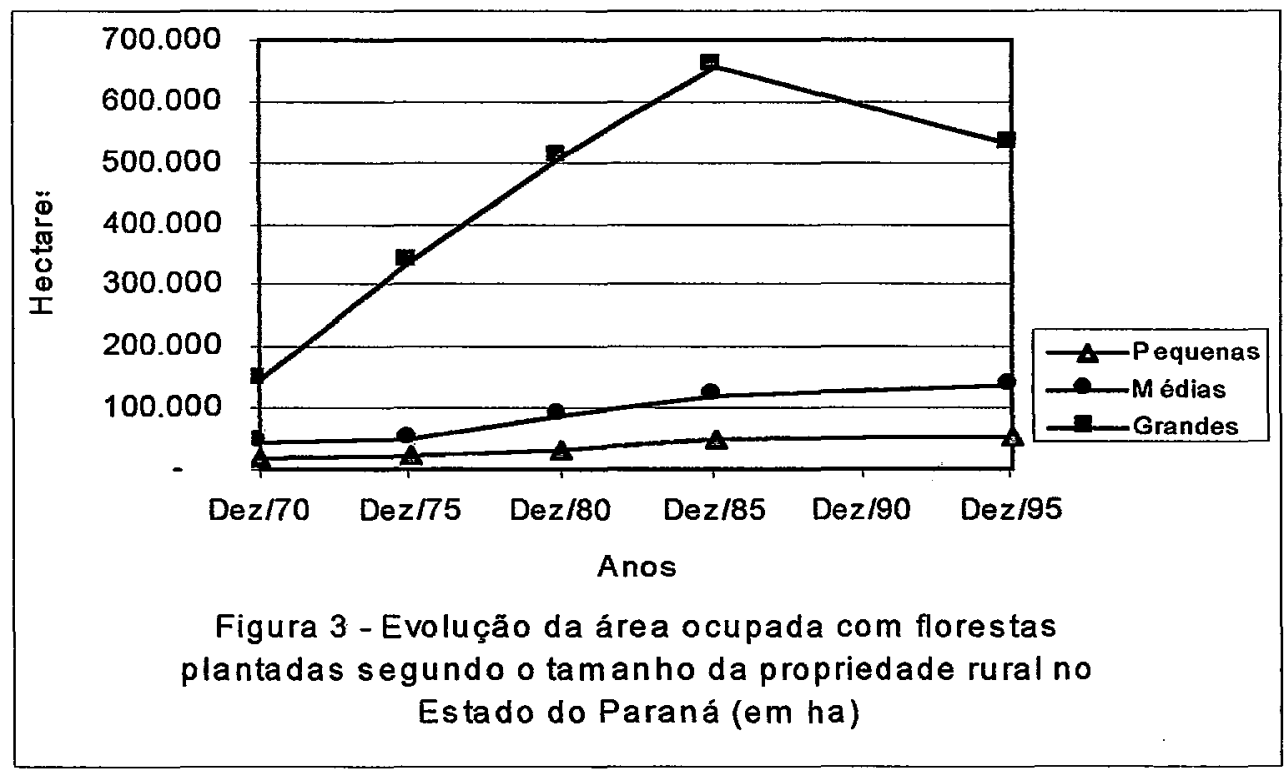

Fonte: elaborados a partir de dados do Censo Agropecuário (vários números) 
Examinando a tabela 23, constata-se que, praticamente, todos os estabelecimentos rurais expandiram continuamente a sua área reflorestada no período de 1970 a 1995. As únicas exceções foram os estabelecimentos dedicados a horticultura/floricultura, que apresentaram redução da área reflorestada no período de 1980 a 1985, e os estabelecimentos dedicados a silvicultura que, assim como nos Estados de Minas Gerais e São Paulo, apresentaram redução da área reflorestada no período de 1985 a 1995.

Tabela 23 - Área ocupada com florestas plantadas segundo a atividade econômica principal no Estado do Paraná (em ha).

\begin{tabular}{|c|c|c|c|c|c|}
\hline $\begin{array}{l}\text { Utilização das } \\
\text { Terras / Ano }\end{array}$ & $31 / 12 / 70$ & $31 / 12 / 75$ & $31 / 12 / 80$ & $31 / 12 / 85$ & $31 / 12 / 95$ \\
\hline Agricultura & $31.787^{1}$ & 50.648 & 90.791 & 106.548 & 106.818 \\
\hline Pecuária & 14.887 & 22.296 & 37.011 & 65.033 & 67.543 \\
\hline Agropecuária & * & 2.869 & 3.805 & 4.433 & 24.030 \\
\hline $\begin{array}{l}\text { Horticultura e } \\
\text { Floricultura }\end{array}$ & 49 & 405 & 500 & 409 & 2.082 \\
\hline Silvicultura & 144.478 & 306.857 & 428.418 & 564.849 & 511.307 \\
\hline Avicultura & 239 & 467 & 1.109 & 1.801 & $*$ \\
\hline $\begin{array}{l}\text { Apicultura/ } \\
\text { Cunicultura / } \\
\text { Sericicultura }\end{array}$ & 29 & 99 & 359 & 725 & * \\
\hline Extração Vegetal & 7.524 & 24.219 & 63.666 & 75.755 & * \\
\hline Outros & $6.170^{2}$ & - & - & - & $1.346^{3}$ \\
\hline Total & 205.163 & 407.860 & 625.659 & 819.553 & 713.126 \\
\hline
\end{tabular}

Fonte: Censo Agropecuário (vários números)

\footnotetext{
* Não disponível

${ }^{1}$ Refere-se à agricultura e agropecuária.

${ }^{2}$ Inclui invernadas, campos de engorda e finalidades especiais.

${ }^{3}$ Inclui pesca, aqüicultura e produção de carvão vegetal.
} 


\section{ANÁLISE DA RENTABILIDADE ECONÔMICA DOS REFLORESTAMENTOS EM PEQUENOS E MÉDIOS IMÓVEIS RURAIS}

O propósito desse capítulo é avaliar a rentabilidade econômica de projetos de reflorestamento com espécies arbóreas exóticas em pequenos e médios imóveis rurais nos Estados de Minas Gerais, Paraná e São Paulo. Procura-se avaliar como os programas analisados no capítulo 2 afetam essa rentabilidade.

Primeiramente, são discutidos e selecionados os métodos mais adequados para a avaliação econômica de projetos (item 4.1). Em seguida, comenta-se a área em estudo, os dados utilizados e as condições preliminares estabelecidas para a avaliação econômica, em condições deterministas, de projetos de reflorestamento com eucalipto (item 4.2). A análise de rentabilidade é feita, então, em três situações: análise determinista (item 4.3), análise de sensibilidade (item 4.4) e análise de risco pela simulação de Monte Carlo (item 4.5).

Visando ter projetos comparáveis entre os Estados, escolheu-se como espécie arbórea exótica o eucalipto. A escolha dessa espécie deve-se ao fato de ser a mais utilizada nos fomentos florestais nos Estados aqui analisados. Segundo as informações da BRACELPA (1998), essa espécie representou $62,3 \%$ do fomento florestal das empresas de papel e celulose no ano de 1998.

\subsection{Métodos de avaliação econômica de projetos}

Antes de iniciar a discussão sobre os métodos utilizados para a avaliação econômica de projetos é necessário esclarecer alguns conceitos que serão empregados no 
presente capítulo. Denominam-se projetos de investimentos toda a aplicação de capital que tenha a finalidade de obtënção de receitas. Para definir os principais indicadores de rentabilidade supõe-se uma análise em condições deterministas.

Todo projeto de investimento supõe um fluxo de caixa que é definido como a apresentação das receitas e despesas monetárias incorridas ao longo do tempo. Segundo Gitman (1984, p. 419), os padrões de fluxo de caixa relacionados com projetos de investimento de capital podem ser classificados como convencionais e não convencionais. Os fluxos de caixa convencionais consistem numa saída (despesa) inicial de caixa seguida por uma série de entradas (receitas líquidas). Nos fluxos de caixa não convencionais existe uma saída (despesa) inicial que não é seguida por uma série de entradas. Não existe um padrão definido na composição do fluxo de caixa que apresenta mais de uma variação "receitas/despesas". Assim, receitas alternadas com despesas e uma receita seguida por despesas são exemplos de padrões não convencionais de fluxo de caixa. Note que o reflorestamento com eucalipto é um projeto de investimento do tipo não convencional, visto que apresenta mais de uma variação de sinal no seu fluxo líquido de caixa, variações estas correspondentes a receitas obtidas com os cortes rasos alternados com os custos de implantação, manutenção, exploração e transporte.

Existem métodos de avaliação de projetos que não consideram os custos de oportunidade do dinheiro ao longo do tempo. Dentre eles tem-se o Prazo de Recuperação do Capital ("payback simples") que mede, em geral, o tempo necessário para que o investidor recupere o montante investido. Apesar de suas limitações, o método pode ser útil como um indicador auxiliar no processo de análise de projetos.

Segundo Azevedo Filho (1995), o “Payback" Simples (PBS) é obtido por:

$$
\mathrm{PSB}=\mathrm{k}, \text { tal que } \sum_{i=0}^{k} F i \geq 0 \mathrm{e} \sum_{i=0}^{k-1} F i<0 \quad \text { onde, }
$$

$F i$ é o valor de receita menos custos no período $i$.

As técnicas mais sofisticadas para seleção e avaliação de projetos consideram o custo de uso do capital ao longo do tempo. Elas descontam os fluxos de caixa da 
empresa a uma dada taxa que é conhecida por taxa de desconto ou custo de oportunidade. Dentre esses métodos, os mais conhecidos são: "Payback" Econômico, Taxa Interna de Retorno (TIR), Valor Presente ou Valor Atual, a Relação Benefício/Custo, Custo Total Atualizado e o Valor Esperado da Terra (VET).

O "Payback" Econômico é obtido por:

$$
\mathrm{PBE}=\mathrm{k} \text {, tal que } \sum_{i=0}^{k}\left[F i /(1+\rho)^{i}\right] \geq 0 \text { e } \sum_{i=0}^{k-1}\left[F i /(1+\rho)^{i}\right]<0 \text { onde, }
$$

$F i$ é o valor de receita menos custo no período $i$, e $\rho$ é a taxa de juros.

A Taxa Interna de Retorno (TIR) é definida como sendo a taxa de desconto que faz o valor atual dos fluxos líquidos de caixa de um projeto igual a zero, ou seja:

$$
\begin{aligned}
& \text { TIR }=\rho^{*} \text {, tal que } \sum_{i=0}^{n} L i\left(1+\rho^{*}\right)^{-i}=0 \text { onde, } \\
& \rho^{*}=\text { taxa de desconto e } \\
& L i=\text { fluxo líquido de caixa no período } i \text { (= receitas no período } i-\text { custos no }
\end{aligned}
$$
período $i$ ).

Segundo Noronha (1987) o projeto é aceito se apresentar TIR maior do que a taxa de juros do mercado (que representa o custo de oportunidade do capital para a empresa).

O principal aspecto da TIR é a sua dependência das características do fluxo de caixa e, dessa maneira, mudanças nos fluxos modificam a TIR de um projeto. Existe a possibilidade de ocorrência de mais de uma TIR em projetos do tipo não convencional (como é o caso de projetos de reflorestamento). O mesmo não se verifica quando da adoção do método do Valor Atual ou Valor Presente.

Para Noronha (1987) as maiores vantagens atribuídas à TIR é que, primeiro, ela representa uma taxa de juros sobre o investimento e pode, dessa maneira, ser 
diretamente comparada com o custo do capital; e, segundo, para o fim específico de seu cálculo não é necessário o conhecimento prévio do fator de desconto (ou seja, da taxa de juros).

Segundo Capp Filho (1976), o Valor Atual (VA) de um fluxo de caixa a dada taxa de juros é a quantia equivalente, no presente, à soma do fluxo em questão. O valor atual é indicado como o método que produz resultados mais consistentes em projetos do tipo não convencional.

O Valor Atual é obtido por:

$$
\mathrm{VA}=\sum_{i=0}^{n} \frac{L i}{(1+\rho)^{i}} \text { onde, }
$$

$\rho=$ taxa de desconto relevante para a empresa e

$L i=$ fluxo líquido (receita menos custo) no período $i$.

$n=$ horizonte do projeto, em número de períodos.

Para que um projeto seja considerado economicamente viável é necessário que $\mathrm{VA}>0$.

As deficiências do uso do método do Valor Atual surgem quando se tem que ordenar projetos com vida útil e investimentos iniciais diferentes. Além disso, na utilização do VA é necessária uma adequada escolha da taxa de juros correspondente ao custo de oportunidade do capital, uma vez que sua utilização influencia fortemente a ordenação de projetos de investimentos.

A relação Benefício-Custo (RBC) é um dos indicadores de avaliação de projetos mais usados devido, principalmente, à facilidade de sua interpretação. Segundo Azevedo Filho (1995), é definida por: 


$$
\begin{aligned}
& \mathrm{RBC}=\frac{\sum_{i=0}^{n} \beta i /(1+\rho)^{i}}{\sum_{i=0}^{n} C i /(1+\rho)^{i}} \text { onde, } \\
& \beta i=\text { receitas do projeto no período } i, \\
& C i=\text { custo do projeto no período } i, \mathrm{e} \\
& \rho=\text { taxa de juros. }
\end{aligned}
$$

Por este método, um projeto é descartado caso $\mathrm{RBC}<1$.

A taxa $\rho$ corresponde ao custo de oportunidade do capital e é utilizada come taxa de desconto dos fluxos. A indicação de $\rho$ é feita com certo grau de arbitrariedade e esta é uma entre as diversas limitações ao uso deste indicador. Além disso, a RBC apresenta insensibilidade à escala e à duração do projeto.

O Custo Total Atualizado (CTA) é um indicador de caráter auxiliar bastante útil na medida da escala do projeto. O CTA permite ao investidor detectar indícios de possíveis restrições orçamentárias.

O CTA é obtido por meio da seguinte fórmula:

$$
\begin{aligned}
& \text { CTA }=\sum_{i=0}^{n} \frac{C i}{(1+\rho)^{i}} \text { onde, } \\
& C i=\text { custos do projeto no período } i, \mathrm{e} \\
& \rho=\text { taxa de juros. }
\end{aligned}
$$

Segundo Rodriguez et al. (1997, p. 18), com relação aos projetos florestais, “a mais grave conseqüência do uso de critérios não adequados à análise de alternativas apresentando diferentes escalas temporais é a não consideração do uso da terra após o término da rotação e a conseqüente subestimação do custo de oportunidade de adiantar ou atrasar o término da rotação". Assim, os autores sugerem o Valor Esperado da Terra 
(VET) como um método que não apresenta restrições quanto ao seu uso na análise de alternativas com diferentes escalas temporais, pois pressupõe a repetição perpétua da alternativa sendo analisada. Dessa maneira, o infinito é utilizado como o horizonte que uniformiza a escala temporal de todas as análises.

Para Rodriguez et al. (1997, p. 19), "O Valor Esperado da Terra (VET) é a simples expressão da soma do valor presente das receitas líquidas obtidas no final de ciclos de produção florestal que se repetem perpetuamente".

O VET pode ser obtido da seguinte maneira:

$$
\mathrm{VET}=\frac{R L i}{\left[(1+\rho)^{i}-1\right]} \text { onde }
$$

$R L i=$ receita líquida capitalizada no período final de cada ciclo de produção, $i=$ duração de cada ciclo de produção, $\rho=$ taxa de juros (taxa de remuneração do capital).

Observe que,

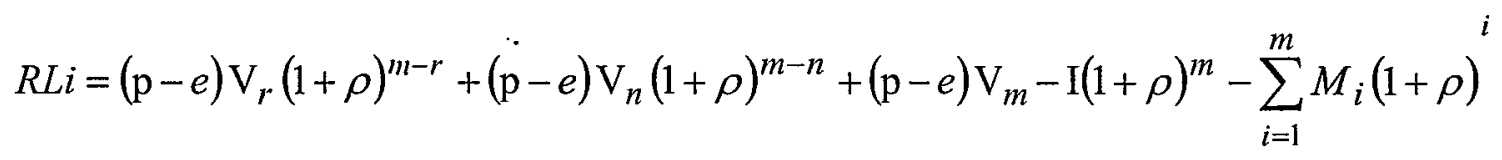
onde:

$R L i=$ receita líquida capitalizada no momento final de cada ciclo de produção;

$\rho=$ taxa de juros (índice de remuneração do capital);

$r=$ ano em que ocorre o primeiro corte;

$n=$ ano em que ocorre o segundo corte;

$\mathrm{m}=$ ano em que ocorre o terceiro corte;

$\mathrm{I}=$ custo de implantação no ano 0 ;

$\mathrm{M}_{i}=$ custo de manutenção no ano $i$;

$\mathrm{V} i=$ volume ou peso de madeira explorada no ano $j(j=r, n, m)$,

$\mathrm{p}=$ preço por unidade de volume ou peso de madeira explorada, $\mathrm{e}$

$\mathrm{e}=$ custo de exploração por unidade de volume ou peso. 
O VET considera que a terra será utilizada para a condução de uma série infinita de rotações florestais idênticas. Supõe que o Valor Presente dessa série é um critério adequado de valoração da terra.

A idéia do VET é determinar qual é a renda líquida atual a ser obtida de uma área (por exemplo, $1 \mathrm{ha}$ ) que será eternamente coberta com floresta plantada. Se essa renda líquida for superior ao custo de aquisição da terra, o produtor terá lucro ao adquirir a terra e implantar o projeto de reflorestamento. Assim, para que um projeto seja considerado viável é necessário que VET > CAT (custo de aquisição da terra).

Considerando os vários aspectos associados aos projetos florestais e contrapondo as diferentes abrangências dos indicadores optou-se pela aplicação de todos o métodos de análise econômica de projetos acima mencionados, buscando maior confiabilidade nos resultados apresentados. O cálculo das estimativas dos indicadores de rentabilidade será obtido a partir do programa DETERPRJ (Sistema para análise de projetos em condições deterministas) ${ }^{12}$.

\subsection{Projetos analisados e fonte dos dados}

Analisa-se a rentabilidade de reflorestamentos com eucalipto em algumas regiões dos Estados de São Paulo, Minas Gerais e Paraná. Sobre esses projetos dois pontos iniciais devem ser destacados: primeiro, considera-se apenas o plantio de eucalipto, que é a espécie mais utilizada nos fomentos florestais, apesar do Pinus também se destacar no caso do Paraná; segundo, definiu-se os projetos para determinadas áreas dos Estados em análise onde o fomento tem sido atuante.

Em São Paulo, os projetos considerados dizem respeito às regiões de Penápolis, Assis e Piracicaba. Os dados sobre as operações utilizadas, seus respectivos coeficientes técnicos e produtividade alcançada nos plantios foram obtidas junto a Florespi que compõe o CONIN ${ }^{13}$. Em Minas Gerais, os dados para estimação dos custos foram

\footnotetext{
${ }^{12}$ Para maiores informações sobre o programa ver Azevedo Filho. DETERPRJ - Manual do usuário Versão 1.00. USP/CIAGRI. Piracicaba. 1995. 22p.

${ }^{13}$ Essas informações foram fornecidas pelo engenheiro florestal Ricardo Otto Leão Schmdit.
} 
obtidos no Programa Fazendeiro Florestal realizado na região do Vale do Rio Doce e foram coletados junto a uma empresa participante do programa ${ }^{14}$. No Estado do Paraná, os dados sobre as operações utilizadas, seus respectivos coeficientes técnicos $\mathrm{e}$ produtividade alcançada nos. plantios foram fundamentados em Rodigheri \& Pinto (1997).

As planilhas referentes ao Paraná e São Paulo registram os coeficientes médios obtidos nas regiões em estudo e os preços médios dos fatores de produção vigentes no mês de novembro de 1999 para todo o Estado (apêndices 2 e 4). A planilha de custo referente a Minas Gerais registra os coeficientes técnicos e preços específicos à empresa participante do Programa Fazendeiro Florestal em novembro de 1999 e não para todo o Estado (apêndice 3).

Observaram-se diferenças entre os sistemas de plantio e manutenção dos Estados (observe o quadro 3), apesar de plantarem a mesma espécie no mesmo sistema de rotação.

\subsubsection{Considerações sobre os dados}

Para proceder à análise econômica foram considerados:

\section{- Custo de Implantação, Manutenção e de Corte}

Considerou-se uma rotação de 21 anos, com cortes a cada sete anos. De acordo com as características da cultura do eucalipto somente a partir do $7^{\circ}$ ano, aproximadamente, os eucaliptos entram na fase de corte, apresentando, assim, as primeiras receitas. $\mathrm{O}$ primeiro ano do investimento (ano 0 ) representa o custo de implantação do plantio. Os custos ocorridos nos $7^{\circ}, 14^{\circ}$ e $21^{\circ}$ anos são considerados custos de exploração. Nos demais anos tem-se o custo de manutenção. Os custos de manutenção e exploração são contabilizados no final de cada ano de suas respectivas ocorrências.

\footnotetext{
${ }^{14}$ Informações fornecidas por Domício Lott, supervisor de Operação Florestal da empresa participante do Programa Fazendeiro Florestal.
} 
Para determinação do custo de mão-de-obra considerou-se o valor pago pelo agricultor ao trabalhador diarista em cada Estado. Esse valor foi usado para representar o custo de oportunidade da mão-de-obra familiar.

Quadro 3 - Diferenças entre os sistemas de plantio, manutenção, exploração e comercialização dos produtos oriundos dos reflorestamentos em pequenos e médios imóveis rurais dos Estados de Minas Gerais, Paraná e São Paulo.

\begin{tabular}{|c|c|c|c|}
\hline Itens & Minas Gerais & Paraná & São Paulo \\
\hline Preparo do solo & Manual & Mecanizado & Mecanizado \\
\hline $\begin{array}{l}\text { Controle de } \\
\text { pragas }\end{array}$ & \begin{tabular}{|l} 
Manual, com uso \\
intensivo de formicidas na \\
implantação (são \\
realizados 3 cọmbates a \\
formigas) e nos anos \\
$1,2,3,8,9,10,15,16$ e 17. \\
\end{tabular} & $\begin{array}{l}\text { Aplicação manual de } \\
\text { formicidas no plantio e } \\
\text { rebrota }(8 \text { e } 15) .\end{array}$ & $\begin{array}{l}\text { Manual, com uso de } \\
\text { formicidas anualmente. }\end{array}$ \\
\hline $\begin{array}{l}\text { Controle de } \\
\text { Gramíneas }\end{array}$ & $\begin{array}{l}\text { A aplicação de herbicidas } \\
\text { é manual. }\end{array}$ & $\begin{array}{l}\text { Há aplicação mecanizada } \\
\text { de herbicidas apenas no } 1^{\circ} \\
\text { ano de manutenção. }\end{array}$ & $\begin{array}{l}\text { Não ocorre a aplicação } \\
\text { de herbicidas. }\end{array}$ \\
\hline Adubação & $\begin{array}{l}\text { Manual. Ocorre a } \\
\text { adubação no plantio (ano } \\
\text { de implantação do } \\
\text { reflorestamento, ano zero) } \\
\text { e a adubação de cobertura } \\
\text { nos anos } 1,8 \text { e } 15 .\end{array}$ & $\begin{array}{l}\text { Mecanizada. Adubação } \\
\text { apenas no plantio (ano de } \\
\text { implantação do } \\
\text { reflorestamento, ano zero). }\end{array}$ & $\begin{array}{l}\text { Mecanizada. Adubação } \\
\text { apenas no plantio (ano } \\
\text { de implantação do } \\
\text { reflorestamento, ano } \\
\text { zero). }\end{array}$ \\
\hline Rotação & $\begin{array}{l}\text { Consideram-se projetos } \\
\text { com implantação no ano } \\
\text { zero e cortes no } 7^{\circ}, 14^{\circ} \mathrm{e} \\
21^{\circ} \text { anos. }\end{array}$ & $\begin{array}{l}\text { Consideram-se projetos } \\
\text { com implantação no ano } \\
\text { zero e cortes no } 7^{\circ}, 14^{\circ} \mathrm{e} \\
21^{\circ} \text { anos. }\end{array}$ & $\begin{array}{l}\text { Consideram-se projetos } \\
\text { com implantação no ano } \\
\text { zero e cortes no } 7^{\circ}, 14^{\circ} \mathrm{e} \\
21^{\circ} \text { anos. }\end{array}$ \\
\hline Produtos & $\begin{array}{l}\text { Madeira para celulose no } \\
1^{\circ} \text { e } 2^{\circ} \text { corte e madeira } \\
\text { para lenha no } 3^{\circ} \text { corte. }\end{array}$ & $\begin{array}{l}\text { Madeira para lenha nos três } \\
\text { cortes. }\end{array}$ & $\begin{array}{l}\text { Madeira para lenha nos } \\
\text { três cortes. }\end{array}$ \\
\hline Produtividade & $\begin{array}{l}375 \text { st/ha no primeiro } \\
\text { corte }{ }^{*}, 340 \text { st } / \text { ha no } \\
\text { segundo corte e } 300 \text { st/ha } \\
\text { no terceiro corte. }\end{array}$ & $\begin{array}{l}321 \text { st/ha no primeiro corte, } \\
307 \text { st/ha no segundo corte } \\
\text { e } 274 \text { st/ha no terceiro } \\
\text { corte. }\end{array}$ & $\begin{array}{l}350 \text { st/ha no primeiro } \\
\text { corte, } 310 \text { st/ha no } \\
\text { segundo corte e } 280 \\
\text { st/ha no terceiro corte. }\end{array}$ \\
\hline
\end{tabular}

Fonte: dados de pesquisa

* a produtividade do primeiro corte é de 400 st/ha, dos quais 25 st ficam com a empresa fomentadora

A metodologia de cálculo do custo do conjunto mecanizado utilizada no trabalho está exposta em Apêndice 5.

Os custos de insumos foram tomados como sendo o custo de aquisição dos mesmos ao longo do horizonte do empreendimento. 


\section{- Preço da Madeira}

Para o Paraná e São Paulo foram considerados os preços médios da lenha de eucalipto empilhada na propriedade, oriunda dos cortes da madeira. Esses valores foram obtidos junto ao Instituto Ambiental do Paraná, no caso do Paraná, e por pesquisa junto a serrarias no Estado de São Paulo. Para Minas Gerais considerou-se o preço que a empresa participante paga pela madeira para celulose no $1^{0}$ e $2^{2}$ cortes e o preço médio da lenha de eucalipto empilhada na propriedade (produto a se obter no $3^{\circ}$ corte) obtido junto ao Instituto Estadual de Florestas de Minas Gerais.

\section{- Taxa de Desconto}

Os custos das diversas fases do reflorestamento em diferentes anos do investimento foram comparados mediante a utilização de taxas de descontos representando custos de oportunidades do investimento. As taxas referentes ao custo de oportunidade do capital utilizadas no presente trabalho variam ponto a ponto percentuais entre $6 \%$ e $20 \%$ ao ano para verificar o efeito do crescimento do custo de oportunidade do capital sobre a avaliação econômica dos projetos de reflorestamento com eucalipto.

Considerou-se que o proprietário rural dispõe de capital próprio e, portanto, tem a possibilidade de aplicar seus recursos no mercado financeiro. Pode, dessa maneira, optar pelo depósito em caderneta de poupança (aplicação conservadora), obtendo uma taxa líquida real de $6 \%$ ao ano ou, por sua vez, optar por financiamento para projetos de longo prazo junto ao BNDES. Segundo Machado (2000, p. 58) "as taxas de juros de longo prazo têm oscilado entre 9,40\% e 18,06\% (fora o "spread" cobrado pelos bancos) para o período de janeiro de 1996 a março de 1999".

Para cada um dos três projetos (MG, SP e PR), foram criadas duas alternativas para a composição do fluxo de caixa considerando, para os Estados de São Paulo e Paraná, a possibilidade de incluir no fluxo de caixa a doação de mudas ao produtor (SP1 e PR1) ou a aquisição de mudas pelo produtor (SP2 e PR2). Esta situação reflete a diferença entre os programas que doam mudas e aqueles que vendem as mudas. Não 
foram considerados os custos com transporte da madeira, supondo que a mesma é retirada na fazenda.

Na composição do fluxo de caixa de Minas Gerais também foram criadas duas alternativas, ambas implicando na doação de mudas ao produtor, mas tendo esquemas distintos de compra da madeira. Essas alternativas consideram aspectos peculiares ao Programa Fazendeiro Florestal em questão.

Nos sete primeiros anos da cultura, a empresa associada ao produtor rural oferece os insumos e mudas necessárias para o desenvolvimento adequado do plantio. Em troca, o produtor doa um percentual da madeira produzida no primeiro corte para a empresa financiadora. No caso em questão, esse percentual foi de $6,25 \%$. O produtor rural é responsável pelos custos de corte, empilhamento e transporte $(R \$ 7,00 /$ st em novembro de 1999) da madeira doada à empresa financiadora. O restante da madeira é vendido à empresa pelo preço médio de R $\$ 14,25 / \mathrm{st}$, em novembro de 1999 . Os custos referentes ao corte e empilhamento da madeira na fazenda são arcados pelo produtor rural ( $R \$ 4,00 / \mathrm{st}$ em novembro de 1999). A partir do $8^{\circ}$ ano não existe mais a obrigatoriedade de parceria entre o produtor e a empresa, podendo haver ou não a compra da lenha produzida no $2^{0}$ corte pela empresa financiadora. Assim, os custos com o projeto são totalmente repassados ao produtor rural a partir do $8^{\circ}$ ano.

Considerou-se, dessa maneira, a possibilidade de compra, pela empresa, da madeira proveniente do $1^{0}$ corte estando o produtor livre para venda do segundo e terceiro cortes a terceiros (MG1). No caso de venda a terceiros, o preço da lenha de eucalipto considerado foi de R\$10,00/st, obtido junto ao IEF em novembro de 1999. Também foi considerado o custo de exploração estimado em $\mathrm{R} \$ 4,00 /$ st (custo com o corte e empilhamento).

A outra alternativa considerada foi a compra, pela empresa financiadora, da madeira proveniente dos $1^{\circ}$ e $2^{\circ}$ cortes e a venda da madeira proveniente do $3^{\circ}$ corte a terceiros ao preço de mercado (MG2). 
Além disso, considera-se para todos os Estados as possibilidades de incluir ou não, em cada um dos fluxos de caixa, a compra da terra. Portanto, são 12 projetos de reflorestamento analisados conforme ilustra o quadro 4 .

Quadro 4 - Características dos projetos de reflorestamento analisados.

\begin{tabular}{|l|c|c|c|c|c|c|}
\hline \multirow{2}{*}{} & \multicolumn{2}{|c|}{ São Paulo } & \multicolumn{2}{c|}{ Minas Gerais } & \multicolumn{2}{c|}{ Paraná } \\
\cline { 2 - 6 } & $\begin{array}{c}\text { Com } \\
\text { doação das } \\
\text { mudas }\end{array}$ & $\begin{array}{c}\text { Inclui a } \\
\text { aquisição } \\
\text { das mudas }\end{array}$ & $\begin{array}{c}\text { Empresa compra } \\
\text { somente o 10 } \\
\text { corte }\end{array}$ & $\begin{array}{c}\text { Empresa } \\
\text { compra o 1 } \\
\text { e 2 o cortes }\end{array}$ & $\begin{array}{c}\text { Com } \\
\text { doação das } \\
\text { mudas }\end{array}$ & $\begin{array}{c}\text { Inclui a } \\
\text { aquisição } \\
\text { das mudas }\end{array}$ \\
\hline $\begin{array}{l}\text { Não inclui o } \\
\text { custo da terra }\end{array}$ & SP1 & SP2 & MG1 & MG2 & PR1 & PR2 \\
\hline $\begin{array}{l}\text { Inclui o custo } \\
\text { da terra }\end{array}$ & SP3 & SP4 & MG3 & MG4 & PR3 & PR4 \\
\hline
\end{tabular}

Fonte: dados de pesquisa

\subsection{Estimativas dos indicadores de avaliação para os projetos selecionados - a análise determinista}

Os indicadores de avaliação econômica, em condições deterministas, são apresentados em tabelas individuais. Na tabela 24 tem-se o valor atual dos projetos em análise segundo o custo de oportunidade do capital considerado. Os valores sombreados correspondem aos projetos descartados.

No Estado do Paraná, o único projeto rejeitado a taxa de juros superiores a $18 \%$ ao ano é o PR2 (onde há a compra de mudas pelo produtor). Mesmo com o crescimento do custo de oportunidade do capital, o projeto fundamentado na doação de mudas é melhor em relação àquele no qual as mudas são adquiridas pelo produtor rural.

Da mesma maneira, no Estado de Minas Gerais, o projeto onde a empresa financiadora compra a madeira dos dois primeiros cortes é melhor do que aquele onde o produtor rural vende a madeira proveniente dos dois últimos cortes no mercado. 
Tabela 24 - Valores Atuais (VA) dos projetos de reflorestamento, em $\mathrm{R} \$ / \mathrm{ha}$, considerando o custo de oportunidade do capital variando entre $6 \%$ e $20 \%$ ao ano, novembro de 1999 (sem incluir o custo da terra).

\begin{tabular}{|c|c|c|c|c|c|c|}
\hline \multirow{3}{*}{$\begin{array}{l}\text { Custo de } \\
\text { Oportuni- } \\
\text { dade (\%) }\end{array}$} & \multicolumn{2}{|c|}{ Minas Gerais } & \multicolumn{2}{|c|}{ Paraná } & \multicolumn{2}{|c|}{ São Paulo } \\
\hline & $\begin{array}{c}\text { Compra } \\
\text { somente do } \\
\text { 1 corte }\end{array}$ & $\begin{array}{c}\text { Compra do } 1^{\circ} \mathrm{e} \\
\text { do } 2^{\circ} \text { cortes }\end{array}$ & $\begin{array}{c}\text { Com doação de } \\
\text { mudas }\end{array}$ & $\begin{array}{l}\text { Com compra } \\
\text { de mudas }\end{array}$ & $\begin{array}{c}\text { Com doação de } \\
\text { mudas }\end{array}$ & $\begin{array}{l}\text { Com compra } \\
\text { de mudas }\end{array}$ \\
\hline & MG1 & MG2 & PR1 & PR2 & SP1 & SP2 \\
\hline 6 & $2.275,64$ & $2.913,58$ & $1.333,25$ & $1.204,94$ & $2.347,77$ & $2.201,13$ \\
\hline 7 & $2.019,29$ & $2.578,67$ & $1.150,37$ & $1.022,06$ & $2.063,56$ & $1.916,92$ \\
\hline 8 & $1.793,96$ & $2.285,05$ & 991,89 & 863,58 & $1.816,56$ & $1.669,92$ \\
\hline 9 & $1.595,06$ & $2.026,71$ & 854,00 & 725,69 & $1.601,05$ & $1.454,41$ \\
\hline 10 & $1.418,78$ & $1.798,64$ & 733,56 & 605,25 & $1.412,28$ & $1.265,64$ \\
\hline 11 & $1.261,94$ & $1.596,61$ & 627,97 & 499,66 & $1.246,32$ & $1.099,68$ \\
\hline 12 & $1.121,90$ & $1.417,09$ & 535,06 & 406,75 & $1.099,89$ & 953,25 \\
\hline 13 & 996,42 & $1.257,08$ & 453,01 & 324,70 & 970,25 & 823,61 \\
\hline 14 & 883,63 & $1.114,04$ & 380,32 & 252,01 & 855,08 & 708,44 \\
\hline 15 & 781,93 & 985,83 & 315,70 & 187,39 & 752,45 & 605,81 \\
\hline 16 & 689,97 & 870,60 & 258,08 & 129,77 & 660,72 & 514,08 \\
\hline 17 & 606,59 & 766,77 & 206,54 & 78,23 & 578,48 & 431,84 \\
\hline 18 & 530,80 & 672,99 & 160,32 & 32,01 & 504,54 & 357,90 \\
\hline 19 & 461,74 & 588,09 & 118,75 & 956 & 437,90 & 291,26 \\
\hline 20 & 398,68 & 511,06 & 81,26 & $\$ 4705$ & 377,69 & 231,05 \\
\hline
\end{tabular}

Fonte: valores calculados pela autora com base nos dados do Apêndice 1

Ao incluir a compra da terra nos custos de implantação dos projetos de reflorestamentos tem-se que MG3 e MG4 são considerados economicamente viáveis para todos os custos de oportunidade do capital considerado (tabela 25). Por outro lado, os projetos PR3 e PR4 são rejeitados a partir da taxa de juros de 7\% ao ano e os projetos SP3 e SP4 são rejeitados a partir da taxa de juros de $9 \%$ ao ano. 
Tabela 25 - Valores Atuais (VA) dos projetos de reflorestamento, em R\$/ha, considerando o custo de oportunidade do capital variando entre $6 \%$ e $20 \%$ ao ano, novembro de 1999 (incluindo o custo da terra).

\begin{tabular}{|c|c|c|c|c|c|c|}
\hline \multirow{3}{*}{$\begin{array}{l}\text { Custo de } \\
\text { Oportuni- } \\
\text { dade (\%) }\end{array}$} & \multicolumn{2}{|c|}{ Minas Gerais } & \multicolumn{2}{|c|}{ Paraná } & \multicolumn{2}{|c|}{ São Paulo } \\
\hline & $\begin{array}{c}\text { Compra } \\
\text { somente do } \\
\text { 1 }^{\circ} \text { corte }\end{array}$ & $\begin{array}{c}\text { Compra do } 1^{\circ} \mathrm{e} \\
\text { do } 2 \stackrel{\circ}{\circ} \text { cortes }\end{array}$ & $\begin{array}{l}\text { Com doação de } \\
\text { mudas }\end{array}$ & $\begin{array}{l}\text { Com compra } \\
\text { de mudas }\end{array}$ & $\begin{array}{c}\text { Com doação de } \\
\text { mudas }\end{array}$ & $\begin{array}{l}\text { Com compra } \\
\text { de mudas }\end{array}$ \\
\hline & MG3 & MG4 & PR3 & $\begin{array}{l}\text { PR4 } \\
\end{array}$ & $\overline{\text { SP3 }}$ & SP4 \\
\hline 6 & $1.992,12$ & $2.631,24$ & 410,34 & 282,03 & $1.193,86$ & $1.047,22$ \\
\hline 7 & $1.714,88$ & $2.275,27$ & 158,63 & 30,32 & 823,60 & 676,96 \\
\hline 8 & $1.472,55$ & $1.964,51$ & 5389 & -18420 & 506,54 & 359,90 \\
\hline 9 & $1.259,78$ & $1.692,19$ & 239449 & -36780 & 233,88 & 87,24 \\
\hline 10 & $1.072,17$ & $1.452,69$ & 39728 & $-525,59$ & 1. 59 & 148.23 \\
\hline 11 & 906,07 & $1.241,30$ & 53345 & $-661,70$ & 205,79 & 35243 \\
\hline 12 & 758,43 & $1.054,11$ & 651.45 & $-779,16$ & $383,5 \%$ & 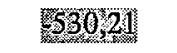 \\
\hline 13 & 626,72 & 887,80 & 75410 & -8824 & $538 \% 98$ & 685,62 \\
\hline 14 & 508,79 & 739,57 & 843,76 & $-972,0$ & 67536 & 822,00 \\
\hline 15 & 402,86 & 607,08 & 92236 & -1.0506 & 995.4 & 94211 \\
\hline 16 & 307,41 & 488,32 & 99153 & $-1119,84$ & 90165 & 1048,29 \\
\hline 17 & 221,14 & 381,57 & 1005262 & -1.18093 & 99583 & $1242 \%$ \\
\hline 18 & 142,96 & 285,36 & 1.106. & $-1.235,0$ & 107966 & 11226,30 \\
\hline 19 & 71,92 & 198,45 & 115490 & $-1.283,21$ & 11154,51 & 12301,15 \\
\hline 20 & 7,21 & 119,76 & 1.19785 & $-1.326,16$ & 1221,56 & 1568,290 \\
\hline
\end{tabular}

Fonte: valores calculados pela autora com base nos dados do Apèndice 1

O resultado acima ressalta a importância de um esquema de compra da madeira por parte da empresa fomentadora em garantir rentabilidade no reflorestamento em áreas que possam ter outra finalidade agrícola, e, portanto, onde o custo da terra não pode ser desconsiderado na avaliação econômica de projetos.

Os resultados da avaliação dos projetos pelo método da relação benefício/custo (RBC) se encontram nas tabelas 26 e 27. Os projetos considerados inviáveis economicamente são aqueles onde $\mathrm{RBC}<1$, como visto anteriormente. Quando não se considera a compra da terra (tabela 26), o único projeto rejeitado é PR2 a partir da taxa de juros de $19 \%$ ao ano. Os demais projetos apresentam $\mathrm{RBC}>1$. 
Tabela 26- Relação Benefício/Custo ( $\mathrm{RBC}$ ) dos projetos de reflorestamento considerando o custo de oportunidade do capital variando entre $6 \%$ e $20 \%$ ao ano, novembro de 1999 (sem incluir o custo da terra).

\begin{tabular}{|c|c|c|c|c|c|c|}
\hline \multirow{3}{*}{$\begin{array}{l}\text { Custo de } \\
\text { Oportuni- } \\
\text { dade (\%) }\end{array}$} & \multicolumn{2}{|c|}{ Minas Gerais } & \multicolumn{2}{|c|}{ Paraná } & \multicolumn{2}{|c|}{ São Paulo } \\
\hline & $\begin{array}{c}\text { Compra } \\
\text { somente do } \\
1^{\circ} \text { corte }\end{array}$ & $\begin{array}{l}\text { Compra do } 1^{\circ} \mathrm{e} \\
\text { do } 2{ }^{\circ} \text { cortes }\end{array}$ & $\begin{array}{l}\text { Com doação de } \\
\text { mudas }\end{array}$ & $\begin{array}{l}\text { Com compra } \\
\text { de mudas }\end{array}$ & $\begin{array}{c}\text { Com doação de } \\
\text { mudas }\end{array}$ & $\begin{array}{l}\text { Com compra } \\
\text { de mudas }\end{array}$ \\
\hline & MGI & $\overline{\text { MG2 }}$ & PR1 & $\overline{\text { PR2 }}$ & SP1 & SP2 \\
\hline 6 & 1,62 & 1,79 & 2,44 & 2,14 & 3,25 & 2,85 \\
\hline 7 & 1,60 & 1,77 & 2,32 & 2,02 & 3,11 & 2,70 \\
\hline 8 & 1,58 & 1,74 & 2,20 & 1,90 & 2,97 & 2,56 \\
\hline 9 & 1,56 & 1,71 & 2,08 & 1,79 & 2,83 & 2,42 \\
\hline 10 & 1,54 & 1,69 & 1,98 & 1,69 & 2,70 & 2,29 \\
\hline 11 & 1,52 & 1,66 & 1,87 & 1,59 & 2,57 & 2,17 \\
\hline 12 & 1,49 & 1,62 & 1,77 & 1,50 & 2,45 & 2,05 \\
\hline 13 & 1,47 & 1,59 & 1,68 & 1,41 & 2,33 & 1,94 \\
\hline 14 & 1,44 & 1,56 & 1,59 & 1,33 & 2,22 & 1,84 \\
\hline 15 & 1,42 & 1,53 & 1,51 & 1,25 & 2,12 & 1,74 \\
\hline 16 & 1,39 & 1,49 & 1,43 & 1,18 & 2,01 & 1,64 \\
\hline 17 & 1,36 & 1,46 & 1,35 & 1,11 & 1,92 & 1,55 \\
\hline 18 & 1,34 & 1,43 & 1,28 & 1,05 & 1,82 & 1,47 \\
\hline 19 & 1,31 & 1,39 & 1,21 & 0,99 & 1,73 & 1,39 \\
\hline 20 & 1,28 & $1 ; 36$ & 1,15 & 0,93 & 1,65 & 1,32 \\
\hline
\end{tabular}

Fonte: valores calculados pelo autor com base nos dados do Apêndice 1

Quando a compra da terra é considerada (tabela 27), os projetos PR3 e PR4 são rejeitados a partir da taxa de juros de $8 \%$ ao ano. SP3 e SP4 são rejeitados a partir da taxa de juros de $10 \%$ ao ano. MG3 é rejeitado a partir da taxa de juros de $20 \%$ ao ano. O projeto MG4 é viável economicamente à taxa de juros de $20 \%$ ao ano. Note que mesmo incluindo a compra da terra no custo de implantação dos reflorestamentos, os projetos podem ser ordenados na seguinte sequiência (dos melhores para os piores): MG4, MG3, SP3, SP4, PR3 e PR4. 
Tabela 27- Relação Benefício/Custo (RBC) dos projetos de reflorestamento considerando o custo de oportunidade do capital variando entre $6 \%$ e $20 \%$ ao ano, novembro de 1999 (incluindo o custo da terra).

\begin{tabular}{|c|c|c|c|c|c|c|}
\hline \multirow{3}{*}{$\begin{array}{l}\text { Custo de } \\
\text { Oportuni- } \\
\text { dade (\%) }\end{array}$} & \multicolumn{2}{|c|}{ Minas Gerais } & \multicolumn{2}{|c|}{ Paraná } & \multicolumn{2}{|c|}{ São Paulo } \\
\hline & $\begin{array}{c}\text { Compra } \\
\text { somente do } \\
1^{\circ} \text { corte } \\
\end{array}$ & $\begin{array}{c}\text { Compra do } 1^{\circ} \mathrm{e} \\
\text { do } 2{ }^{\circ} \text { cortes }\end{array}$ & $\begin{array}{c}\text { Com doação de } \\
\text { mudas }\end{array}$ & $\begin{array}{l}\text { Com compra } \\
\text { de mudas }\end{array}$ & $\begin{array}{c}\text { Com doação de } \\
\text { mudas }\end{array}$ & $\begin{array}{l}\text { Com compra } \\
\text { de mudas }\end{array}$ \\
\hline & MG3 & MG4 & PR3 & PR4 & SP3 & $\overline{\text { SP4 }}$ \\
\hline 6 & 1,49 & 1,65 & 1,18 & 1,12 & 1,45 & 1,37 \\
\hline 7 & 1,46 & 1,61 & 1,07 & 1,01 & 1,31 & 1,25 \\
\hline 8 & 1,42 & 1,56 & 0.97 & 0,92 & 1,20 & 1,13 \\
\hline 9 & 1,39 & 1,52 & 0.82 & 0,83 & 1,09 & 1,03 \\
\hline 10 & 1,35 & 1,48 & 0.81 & 076 & 100 & 028 \\
\hline 11 & 1,32 & 1,44 & 0.74 & 069 & 092 & 0,80 \\
\hline 12 & 1,28 & 1,39 & 068 & 0,63 & 084 & 0.79 \\
\hline 13 & 1,25 & 1,35 & 162 & 0,58 & $0.7 \%$ & 073 \\
\hline 14 & 1,21 & 1,31 & 057 & 0,53 & 097 & 0.67 \\
\hline 15 & 1,18 & 1,27 & 053 & 0.49 & 006 & 062 \\
\hline 16 & 1,14 & 1,23 & 0.948 & 045 & 060 & 0359 \\
\hline 17 & 1,11 & 1,18 & 045 & 0,42 & 0.56 & 0,53 \\
\hline 18 & 1,07 & 1,14 & 20424] & 039 & 052 & 042 \\
\hline 19 & 1,04 & 1,10 & 238 & 0,30 & 048 & 045 \\
\hline 20 & 180 & 1,07 & 025 & 0,33 & 0.45 & 0342 \\
\hline
\end{tabular}

Fonte: valores calculados pela autora com base nos dados do Apêndice 1

Comparando a Taxa Interna de Retorno dos projetos sem incluir o custo da terra com o maior custo de oportunidade do capital aqui considerado ( $20 \%$ ao ano), constatase que apenas o projeto PR2 é rejeitado (tabela 28).

Tabela 28 - Taxas Internas de Retorno (TIR) dos projetos de reflorestamento com eucalipto, novembro de 1999 (sem incluir o custo da terra).

\begin{tabular}{ccccccc}
\hline & \multicolumn{2}{c}{ Minas Gerais } & \multicolumn{2}{c}{ Paraná } & \multicolumn{2}{c}{ São Paulo } \\
\cline { 2 - 7 } & $\begin{array}{c}\text { Compra } \\
\text { somente do } \\
1^{\circ} \text { corte }\end{array}$ & $\begin{array}{c}\text { Compra do } \\
1^{\circ} \text { e do } 2 \\
\text { corte }\end{array}$ & $\begin{array}{c}\text { Com doação } \\
\text { de mudas }\end{array}$ & $\begin{array}{c}\text { Com compra } \\
\text { de mudas }\end{array}$ & $\begin{array}{c}\text { Com doação } \\
\text { de mudas }\end{array}$ & $\begin{array}{c}\text { Com } \\
\text { compra de } \\
\text { mudas }\end{array}$ \\
\hline & MG1 & MG2 & PR1 & PR2 & SP1 & SP2 \\
\hline TIR & 29,63 & 30,89 & 22,59 & 18,76 & 30,18 & 25,09 \\
\hline
\end{tabular}

Fonte: valores calculados pela autora com base nos dados do Apêndice 1 
Como era de se esperar, a rentabilidade dos projetos de reflorestamento diminui quando se inclui o custo da terra (tabela 29). Apenas MG3 e MG4 são considerados economicamente viáveis a taxa de juros de $20 \%$ ao ano. No Paraná, os projetos deixam de ser rentáveis a taxa de juros de $8 \%$ ao ano e em São Paulo deixam de ser rentáveis a taxa de juros de $10 \%$ ao ano.

Tabela 29 - Taxas Internas de Retorno (TIR) dos projetos de reflorestamento com eucalipto, novembro de 1999 (incluindo o custo da terra).

\begin{tabular}{ccccccc}
\hline & \multicolumn{2}{c}{ Minas Gerais } & \multicolumn{2}{c}{ Paraná } & \multicolumn{2}{c}{ São Paulo } \\
\cline { 2 - 7 } & $\begin{array}{c}\text { Compra } \\
\text { somente do } \\
\mathbf{1}^{\mathbf{0}} \text { corte }\end{array}$ & $\begin{array}{c}\text { Compra do } \\
1^{\mathbf{0}} \text { e do 2 } \\
\text { corte }\end{array}$ & $\begin{array}{c}\text { Com doação } \\
\text { de mudas }\end{array}$ & $\begin{array}{c}\text { Com compra } \\
\text { de mudas }\end{array}$ & $\begin{array}{c}\text { Com doação } \\
\text { de mudas }\end{array}$ & $\begin{array}{c}\text { Com compra } \\
\text { de mudas }\end{array}$ \\
\cline { 2 - 7 } MG3 & MG4 & PR3 & PR4 & SP3 & SP4 \\
\hline TIR & 20,12 & 21,74 & 7,72 & 7,13 & 9,99 & 9,35
\end{tabular}

Fonte: valores calculados pela autora com base nos dados do Apêndice 1

Observa-se que o preço da terra em São Paulo e Paraná para fins de reflorestamento é mais elevado em relação ao preço da terra em Minas Gerais, o que influencia a rentabilidade dos projetos.

Os resultados das tabelas 28 e 29 ressaltam a importância da doação de mudas para o aumento da rentabilidade dos projetos de reflorestamento. Sem considerar o custo da terra, a doação de mudas ao produtor rural é responsável pelo aumento da rentabilidade em 20,4\% e 20,3\%, respectivamente, no Paraná e em São Paulo. Considerando o custo da terra, a doação de mudas ao produtor rural é responsável pelo acréscimo de 8,3\% e 6,8\% na TIR, respectivamente, nos Estados do Paraná e São Paulo (tabela 29).

Para efeito de avaliação da importância da doação de mudas no Estado de Minas Gerais, os dados da tabela G.12 (apêndice 7) podem ser comparados aos das tabelas $28 \mathrm{e}$ 29. Sem considerar o custo da terra, a doação de mudas e insumos ao produtor rural é responsável pelo aumento de $71,87 \%$ da TIR no projeto MG1 e de $61,98 \%$ no projeto MG2. Considerando o custo da terra, a doação de mudas e insumos ao produtor rural é 
responsável pelo aumento da rentabilidade em $52,19 \%$ no projeto MG3 e $43,88 \%$ no projeto MG4.

Na tabela 30 são apresentadas as estimativas do Custo Total Atualizado (CTA), sem incluir o custo da terra.

Tabela 30 - Custos Totais Atualizados (CTA) dos projetos de reflorestamentos com eucalipto, em R $\$ /$ ha, considerando o custo de oportunidade do capital variando entre $6 \%$ e $20 \%$ ao ano, novembro de 1999 (sem incluir o custo da terra).

\begin{tabular}{|c|c|c|c|c|c|c|}
\hline \multirow{3}{*}{$\begin{array}{l}\text { Custo de } \\
\text { Oportuni- } \\
\text { dade (\%) }\end{array}$} & \multicolumn{2}{|c|}{ Minas Gerais } & \multicolumn{2}{|c|}{ Paraná } & \multicolumn{2}{|c|}{ São Paulo } \\
\hline & $\begin{array}{l}\text { Compra } \\
\text { somente do } \\
1^{0} \text { corte }\end{array}$ & $\begin{array}{c}\text { Compra do } 1^{\circ} \mathrm{e} \\
\text { do } 2{ }^{\circ} \text { cortes }\end{array}$ & $\begin{array}{l}\text { Com doação de } \\
\text { mudas }\end{array}$ & $\begin{array}{l}\text { Com compra } \\
\text { de mudas }\end{array}$ & $\begin{array}{c}\text { Com doação de } \\
\text { mudas }\end{array}$ & $\begin{array}{l}\text { Com compra } \\
\text { de mudas }\end{array}$ \\
\hline & MG1 & MG2 & PR1 & $\overline{\text { PR2 }}$ & SP1 & SP2 \\
\hline 6 & $3.665,73$ & $3.665,73$ & 925,83 & $1.054,14$ & $1.044,09$ & $1.190,73$ \\
\hline 7 & $3.352,66$ & $3.352,66$ & 873,65 & $1.001,96$ & 980,01 & $1.126,65$ \\
\hline 8 & $3.078,48$ & $3.078,48$ & 827,81 & 956,12 & 923,85 & $1.070,49$ \\
\hline 9 & $2.837,44$ & $2.837,44$ & 787,38 & 915,69 & 874,43 & $1.021,07$ \\
\hline 10 & $2.624,78$ & $2.624,78$ & 751,60 & 879,91 & 830,78 & 977,42 \\
\hline 11 & $2.436,50$ & $2.436,50$ & 719,83 & 848,14 & 792,08 & 938,72 \\
\hline 12 & $2.269,22$ & $2.269,22$ & 691,52 & 819,83 & 757,64 & 904,28 \\
\hline 13 & $2.120,12$ & $2.120,12$ & 666,21 & 794,52 & 726,89 & 873,53 \\
\hline 14 & $1.986,79$ & $1.986,79$ & 643,51 & 771,82 & 699,33 & 845,97 \\
\hline 15 & $1.867,21$ & $1.867,21$ & 623,10 & 751,41 & 674,54 & 821,18 \\
\hline 16 & $1.759,64$ & $1.759,64$ & 604,68 & 732,99 & 652,19 & 798,83 \\
\hline 17 & $1.662,60$ & $1.662,60$ & 588,01 & 716,32 & 631,96 & 778,60 \\
\hline 18 & $1.574,83$ & $1.574,83$ & 572,89 & 701,20 & 613,60 & 760,24 \\
\hline 19 & $1.495,23$ & $1.495,23$ & 559,13 & 687,44 & 596,89 & 743,53 \\
\hline 20 & $1.422,85$ & $1.422,85$ & 537,83 & 674,89 & 581,64 & 728,28 \\
\hline
\end{tabular}

Fonte: valores calculados pela autora com base nos dados do Apêndice 1

Na tabela 24 pode-se observar que, à taxa de juros de $6 \%$ ao ano, o projeto MG2 é o mais rentável segundo o método do VA. Assim, o CTA vem adicionar restrições orçamentárias ao empreendedor que descartará o projeto MG2 caso não disponha de R\$ 3.665,73. Raciocínio idêntico se aplica aos demais projetos e taxas de desconto. Quando se considera a compra da terra (tabela 31 ), à taxa de juros de $6 \%$ ao ano, o empreendedor em Minas Gerais necessitará de $\mathrm{R} \$ 4.065,73$ para a implantação do projeto mais rentável. 
Tabela 31 - Custos Totais Atualizados (CTA) dos projetos de reflorestamentos com eucalipto, em R\$/ha, considerando o custo de oportunidade do capital variando entre 6\% e $20 \%$ ao ano, novembro de 1999 (incluindo o custo da terra).

\begin{tabular}{|c|c|c|c|c|c|c|}
\hline \multirow{3}{*}{$\begin{array}{l}\text { Custo de } \\
\text { Oportuni- } \\
\text { dade (\%) }\end{array}$} & \multicolumn{2}{|c|}{ Minas Gerais } & \multicolumn{2}{|c|}{ Paraná } & \multicolumn{2}{|c|}{ São Paulo } \\
\hline & $\begin{array}{c}\text { Compra } \\
\text { somente do } \\
1{ }^{\circ} \text { corte }\end{array}$ & $\begin{array}{l}\text { Compra do } 1^{\circ} \mathrm{e} \\
\text { do } 2 \stackrel{\circ}{\text { cortes }}\end{array}$ & $\begin{array}{c}\text { Com doação de } \\
\text { mudas }\end{array}$ & $\begin{array}{l}\text { Com compra } \\
\text { de mudas }\end{array}$ & $\begin{array}{l}\text { Com doação de } \\
\text { mudas }\end{array}$ & $\begin{array}{c}\text { Com compra } \\
\text { de mudas }\end{array}$ \\
\hline & MG3 & MG4 & PR3 & PR4 & SP3 & SP4 \\
\hline 6 & $4.065,73$ & $4.065,73$ & $2.233,36$ & $2.361,67$ & $2.678,87$ & $2.825,51$ \\
\hline 7 & $3.752,66$ & $3.752,66$ & $2.181,18$ & $2.309,49$ & $2.614,79$ & $2.761,43$ \\
\hline 8 & $3.478,48$ & $3.478,48$ & $2.135,34$ & $2.263,65$ & $2.558,63$ & $2.705,27$ \\
\hline 9 & $3.237,44$ & $3.237,44$ & $2.094,91$ & $2.223,22$ & $2.509,21$ & $2.655,85$ \\
\hline 10 & $3.024,78$ & $3.024,78$ & $2.059,13$ & $2.187,44$ & $2.465,56$ & $2.612,20$ \\
\hline 11 & $2.836,50$ & $2.836,50$ & $2.027,36$ & $2.155,67$ & $2.426,86$ & $2.573,50$ \\
\hline 12 & $2.669,22$ & $2.669,22$ & $1.999,05$ & $2.127,36$ & $2.392,42$ & $2.539,06$ \\
\hline 13 & $2.520,12$ & $2.520,12$ & $1.973,74$ & $2.102,05$ & $2.361,67$ & $2.508,31$ \\
\hline 14 & $2.386,79$ & $2.386,79$ & $1.951,04$ & $2.079,35$ & $2.334,11$ & $2.408,75$ \\
\hline 15 & $2.267,21$ & $2.267,21$ & $1.930,63$ & 2058,94 & $2.309,32$ & $2.455,96$ \\
\hline 16 & $2.159,64$ & $2.159,64$ & $1.912,21$ & $2.040,52$ & $2.286,97$ & $2.433,61$ \\
\hline 17 & $2.062,60$ & $2.062,60$ & $1.895,54$ & $2.023,85$ & $2.266,74$ & $2.413,38$ \\
\hline 18 & $1.974,83$ & $1.974,83$ & $1.880,42$ & $2.008,73$ & $2.248,38$ & $2.395,02$ \\
\hline 19 & $1.895,23$ & $1.895,23$ & $1.866,66$ & $1.994,97$ & $2.231,67$ & $2.378,31$ \\
\hline 20 & $1.822,85$ & $1.822,85$ & $1.854,11$ & $1.982,42$ & $2.216,42$ & $2.363,06$ \\
\hline
\end{tabular}

Fonte: valores calculados pela autora com base nos dados do Apêndice 1

No Estado do Paraná, quando não se considerou no projeto o custo referente à compra da terra, o "Payback" Simples (PBS) foi de 7 anos para ambos os projetos (com doação ou aquisição de mudas) e para todos os custos de oportunidade considerados. Entretanto, o "Payback" Econômico (PBE) se diferenciou no projeto PR2. Para taxas de juros de $15 \%$ até $18 \%$, o prazo indicado pelo PBE foi de 14 , ou seja, 14 anos para a recuperação do capital investido no projeto. Para taxas superiores a $18 \%$, o projeto não apresentou "Payback" Econômico (quadro 5). 
Quadro 5 - Valores do "Payback" econômico (em anos) segundo o projeto e a taxa de juros considerada.

\begin{tabular}{|l|c|c|c|c|c|c|c|c|c|c|c|c|}
\hline $\begin{array}{l}\text { Taxa de } \\
\text { juros } \\
\text { (\%) }\end{array}$ & MG1 & MG2 & MG3 & MG4 & SP1 & SP2 & SP3 & SP4 & PR1 & PR2 & PR3 & PR4 \\
\hline $\mathbf{6}$ & 7 & 7 & 7 & 7 & 7 & 7 & 14 & 14 & 7 & 7 & 21 & 21 \\
$\mathbf{7}$ & 7 & 7 & 7 & 7 & 7 & 7 & 14 & 21 & 7 & 7 & 21 & 21 \\
$\mathbf{8}$ & 7 & 7 & 7 & 7 & 7 & 7 & 21 & 21 & 7 & 7 & s.p. & s.p. \\
$\mathbf{9}$ & 7 & 7 & 7 & 7 & 7 & 7 & 21 & 21 & 7 & 7 & s.p. & s.p. \\
$\mathbf{1 0}$ & 7 & 7 & 7 & 7 & 7 & 7 & s.p. & s.p. & 7 & 7 & s.p. & s.p. \\
$\mathbf{1 1}$ & 7 & 7 & 7 & 7 & 7 & 7 & s.p. & s.p. & 7 & 7 & s.p. & s.p. \\
$\mathbf{1 2}$ & 7 & 7 & 7 & 7 & 7 & 7 & s.p. & s.p. & 7 & 7 & s.p. & s.p. \\
$\mathbf{1 3}$ & 7 & 7 & 7 & 7 & 7 & 7 & s.p. & s.p. & 7 & 7 & s.p. & s.p. \\
$\mathbf{1 4}$ & 7 & 7 & 7 & 7 & 7 & 7 & s.p. & s.p. & 7 & 7 & s.p. & s.p. \\
$\mathbf{1 5}$ & 7 & 7 & 7 & 7 & 7 & 7 & s.p. & s.p. & 7 & 14 & s.p. & s.p. \\
$\mathbf{1 6}$ & 7 & 7 & 7 & 7 & 7 & 7 & s.p. & s.p. & 7 & 14 & s.p. & s.p. \\
$\mathbf{1 7}$ & 7 & 7 & 7 & 7 & 7 & 7 & s.p. & s.p. & 7 & 14 & s.p. & s.p. \\
$\mathbf{1 8}$ & 7 & 7 & 7 & 7 & 7 & 7 & s.p. & s.p. & 7 & 14 & s.p. & s.p. \\
$\mathbf{1 9}$ & 7 & 7 & 7 & 7 & 7 & 7 & s.p. & s.p. & 7 & s.p. & s.p. & s.p. \\
$\mathbf{2 0}$ & 7 & 7 & 14 & 14 & 7 & 7 & s.p. & s.p. & 14 & s.p. & s.p. & s.p. \\
\hline
\end{tabular}

Fonte: valores calculados pelo autor com base nos dados do Apêndice 1

s.p. = sem "payback"

Quando se incluiu a compra da terra no custo de implantação do projeto, o PBS foi de 14 anos para ambos os projetos (aquisição ou doação de mudas) e para todos os custos de oportunidades considerados no Estado do Paraná. Por outro lado, o PBE para taxa de juros de $6 \%$ até $7 \%$ ao ano foi de 21 anos. Para taxa de juros de $8 \%$ até $20 \%$ ao ano os projetos PR3 e PR4 não apresentaram "Payback” Econômico.

Os projetos de investimento considerados para o Estado de São Paulo apresentaram PBS de 7 anos para todos os custos de oportunidade considerados. Para os projetos que não consideram o custo de aquisição da terra (SP1 e SP2), o PBE foi de 7 anos. Considerando o custo de aquisição da terra (SP3 e SP4) o PBE foi de 14 anos à taxa de juros de $6 \%$ ao ano, de 21 anos à taxa de juros de 8 a $9 \%$ ao ano e não definido a partir da taxa de juros de $10 \%$ ao ano.

No Estado de Minas Gerais, quando não foi considerado o custo de aquisição da terra, os projetos MG1 e MG2 apresentaram PBS e PBE de 7 anos. Ao ser considerada a compra da terra, ambos os projetos continuaram a apresentar PBS de 7 anos. Por outro lado, o PBE se diferenciou. Nos projetos MG3 e MG4, o PBE estimado foi de 7 anos 
entre as taxas de juros de $6 \%$ a $19 \%$ ao ano. Para a taxa de $20 \%$ ao ano o PBE estimado foi de 14 anos.

$\mathrm{Na}$ tabela 32 são apresentados os valores esperados da terra (VET) para os projetos cujos fluxos de caixa não incluem o custo de aquisição da terra. Aqueles projetos que apresentam VET inferior ao custo de aquisição da terra são considerados inviáveis economicamente. Em São Paulo o custo de aquisição de cada hectare de terra considerado é de R $\$ 1.634,78$, no Paraná é de $\mathrm{R} \$ 1.307,53$ e em Minas Gerais é de R\$ 400,00 .

Tabela 32 - Valores Esperados da Terra (VET) dos projetos de reflorestamento considerando o custo de oportunidade do capital variando entre $6 \%$ e $20 \%$ ao ano, em R\$/ha, novembro de 1999.

\begin{tabular}{|c|c|c|c|c|c|c|}
\hline \multirow{3}{*}{$\begin{array}{l}\text { Custo de } \\
\text { Oportuni- } \\
\text { dade (\%) }\end{array}$} & \multicolumn{2}{|c|}{ Minas Gerais } & \multicolumn{2}{|c|}{ Paraná } & \multicolumn{2}{|c|}{ São Paulo } \\
\hline & $\begin{array}{l}\text { Compra somente } \\
\text { do } 10 \text { corte }\end{array}$ & $\begin{array}{c}\text { Compra do } 1^{\circ} \mathrm{e} \\
\text { do } 2^{\circ} \text { cortes }\end{array}$ & $\begin{array}{c}\text { Com doação de } \\
\text { mudas }\end{array}$ & $\begin{array}{l}\text { Com compra } \\
\text { de mudas }\end{array}$ & $\begin{array}{c}\text { Com doação de } \\
\text { mudas }\end{array}$ & $\begin{array}{l}\text { Com compra } \\
\text { de mudas }\end{array}$ \\
\hline & MG1 & MG2 & PR1 & PR2 & SP1 & $\overline{\text { SP2 }}$ \\
\hline 6 & $3.222,32$ & $4.127,79$ & $1.888,88$ & $1.707,09$ & $3.326,18$ & $3.118,43$ \\
\hline 7 & $2.660,92$ & $3.399,75$ & $1.516,67$ & $1.347,50$ & $2.720,63$ & $2.527,30$ \\
\hline 8 & $2.237,60$ & $2.851,52$ & 1.23718 & 107,67 & $2.266,90$ & $2.083,90$ \\
\hline 9 & $1.906,37$ & $2.423,42$ & 1021110 & 80974 & $1.914,44$ & $1.739,10$ \\
\hline 10 & $1.639,70$ & $2.079,66$ & 84818 & 69982 & 1632,94 & 14639 \\
\hline 11 & $1.420,06$ & $1.797,46$ & 706,9 & 562 & 1403,1 & 123802 \\
\hline 12 & $1.235,80$ & $1.561,63$ & 58963 & 44822 & 11212,08 & 1050,49 \\
\hline 13 & $1.078,85$ & $1.361,65$ & $490 \pi 0$ & 351971 & 1050,96 & 89212 \\
\hline 14 & 943,48 & $1.190,00$ & 40625 & 2690 & 913,38 & 1567 \\
\hline 15 & 825,47 & $1.041,15$ & B33.4I & 19790 & 794,68 & 639.81 \\
\hline 16 & 721,66 & 910,95 & 27000 & $135 \%$ & 69134 & 53990 \\
\hline 17 & 629,64 & 796,22 & 214,48 & 8124 & 600,70 & 448.42 \\
\hline 18 & 547,52 & 694,47 & 163,44 & 3013 & 520,65 & 36939 \\
\hline 19 & 473,83 & 603,73 & 12191 & 298 & 449,55 & 29901 \\
\hline 20 & 407,37 & 522,42 & 8307 & 48.09 & 386,08 & 236,18 \\
\hline
\end{tabular}

Fonte: valores calculados pela autora com base nos dados do apêndice 1

Quando a taxa de juros é de 7\% ao ano, todos os projetos aqui analisados são considerados viáveis economicamente pelo critério do VET. Os primeiros projetos rejeitados são os PR1 e PR2 quando a taxa de juros é de $8 \%$ ao ano. Os projetos SP1 e SP2 são rejeitados a taxa de juros de $10 \%$ ao ano. Os projetos considerados viáveis a 
taxa de juros de $20 \%$ ao ano são apenas MG1 e MG2. Este último ocorreu porque o custo da terra para reflorestamento em Minas Gerais é, relativamente aos dois outros Estados, pequeno.

Os resultados anteriores da análise determinista demonstraram que o custo de aquisição de mudas afeta significativamente os indicadores de rentabilidade dos projetos de reflorestamento com eucalipto. Isto permite concluir que programas de fomento florestal baseados na doação de mudas são uma boa alternativa para estimular o reflorestamento.

Os resultados da análise determinista também ressaltam o papel do custo da terra em afetar os indicadores de rentabilidade dos projetos de reflorestamento. Isto permite sugerir que o fomento florestal, via doação de mudas, deve priorizar a ocupação de áreas com pouca alternativa de uso da terra e onde, portanto, é baixo o custo deste fator.

Entretanto, considerando-se o longo ciclo da cultura do eucalipto e sabendo-se que as receitas iniciais provêem a partir do $7^{0}$ ano, as decisões sobre os investimentos necessários e riscos inerentes devem ser avaliados sob condições de incerteza. Esta última pode ser feita via a análise de sensibilidade ou através da simulação de Monte Carlo.

\subsection{Análise de Sensibilidade}

A análise de sensibilidade pode ser justificada pela possibilidade de erros nas estimativas dos parâmetros utilizados para a obtenção do fluxo de caixa em questão. No caso do presente trabalho, apesar de fundamentar a construção dos fluxos de caixa nas melhores estimativas das variáveis utilizadas, supõe-se a existência de erro nas estimativas feitas.

Segundo Takitane (1988, p. 38), por meio do método da análise de sensibilidade, as variáveis são selecionadas e arbitrariamente modificadas visando-se avaliar seu efeito sobre a rentabilidade do projeto. Identificando as variáveis que afetam individualmente o resultado do projeto, o tomador de decisões pode observar detalhadamente as alterações 
que ocorrem nessas variáveis. Nesse estudo, a análise de sensibilidade oferece subsídios para a simulação de Monte Carlo.

Para efeito da análise de sensibilidade considerou-se os projetos que apresentam menor rentabilidade na análise determinista, que são: MG3, SP4 e PR4. Esses três projetos incluem o custo da terra e nos casos do SP4 e PR4 a aquisição de mudas. No caso do MG3 as mudas são doadas pela empresa fomentadora a qual se compromete, no entanto, a comprar o volume de madeira do $1^{\circ}$ corte.

A escolha desses projetos e não dos demais listados no quadro 3 se faz propositadamente de modo a identificar outras variáveis (afora o custo de mudas e da terra) que possam ser afetadas por decisões dos produtores e que, por sua vez, alteram significativamente a rentabilidade dos projetos de reflorestamento.

Assim, para realizar a análise de sensibilidade dos projetos de reflorestamentos considerados no presente estudo optou-se, na escolha das variáveis, por aquelas que influenciam diretamente a receita total com a produção de madeira, que são a produtividade florestal e o preço da lenha de eucalipto.

Variou-se a produtividade florestal e o preço da lenha de eucalipto supondo alguns cenários (apêndice 6). A partir disso, estimou-se novamente os Valores Atuais e Taxas Internas de Retorno para os "novos" projetos obtidos: SP4*, PR4* e MG3* à taxa de juros de $6 \%$ ao ano (tabela 33 ).

Observa-se, pela estimativa da TIR, que a queda da produtividade florestal é a variável que tem maior influência no declínio da rentabilidade dos projetos analisados para os Estados de Minas Gerais e Paraná. Neste caso os valores da TIR dos projetos MG3* e PR4*, são respectivamente, 64,76\% e 57,78\% menores que os projetos MG3 e PR4. Os Valores Atuais dos projetos MG3* e PR4* são, respectivamente, 95,36\% e 296,57\%, menores do que os Valores Atuais dos projetos MG3 e PR4.

A produtividade florestal também é a variável com maior impacto no aumento do Valor Atual e da TIR estimados. Os Valores Atuais dos projetos MG3* e PR4* são 
respectivamente, $180,46 \%, 59,42 \%$ maiores do que os dos projetos MG3 e PR4, para a taxa de juros de $6 \%$ ao ano.

Tabela 33 - Valor Atual (VA), Taxa Interna de Retorno (TIR) e variação percentual em relação à análise determinista, para os projetos PR4*, SP4* e MG3* (novos cenários), novembro de 1999.

\begin{tabular}{|c|c|c|c|c|c|c|c|}
\hline \multirow[t]{2}{*}{ Cenário } & \multirow[t]{2}{*}{ Variável } & \multirow[t]{2}{*}{$\begin{array}{c}\text { Variação } \\
\text { Percentual da } \\
\text { variável }\end{array}$} & \multirow[t]{2}{*}{ Projeto } & \multirow[t]{2}{*}{$\begin{array}{c}\text { VA } \\
\text { (R\$/ha) }\end{array}$} & \multirow[t]{2}{*}{ TIR (\%) } & \multicolumn{2}{|c|}{$\begin{array}{l}\text { Variação } \\
\text { percentual em } \\
\text { relação à análise } \\
\text { determinista }\end{array}$} \\
\hline & & & & & & $\overline{\mathbf{V A}}$ & TIR \\
\hline \multirow{6}{*}{ Otimista } & \multirow{3}{*}{ Produtividade } & 62,50 & MG3* & $5.587,12$ & 33,30 & 180,46 & 65,51 \\
\hline & & 24,44 & PR4* & 449,61 & 8,00 & 59,42 & 12,20 \\
\hline & & 40,00 & SP4* & $1.923,09$ & 12,30 & 83,64 & 31,55 \\
\hline & \multirow{3}{*}{$\begin{array}{l}\text { Preço da lenha de } \\
\text { eucalipto }\end{array}$} & 10,00 & MG3* & $2.113,08$ & 20,50 & 6,10 & 1,89 \\
\hline & & 20,00 & PR4* & 349,23 & 7,58 & 23,83 & 6,31 \\
\hline & & 66,67 & SP4* & $2.827,58$ & 14,57 & 170,01 & 55,83 \\
\hline \multirow{6}{*}{ Pessimista } & \multirow{3}{*}{ Produtividade } & $-30,00$ & MG3* & 92,40 & 7,09 & $-95,36$ & $-64,76$ \\
\hline & & $-20,00$ & PR4* & $-554,40$ & 3,01 & $-296,57$ & $-57,78$ \\
\hline & & $-30,00$ & SP4* & $-451,21$ & 3,99 & $-143,09$ & $-57,33$ \\
\hline & \multirow{3}{*}{$\begin{array}{l}\text { Preço da lenha de } \\
\text { eucalipto }\end{array}$} & $-40,00$ & MG3* & 919,94 & 17,21 & $-53,82$ & $-14,46$ \\
\hline & & $-20,00$ & PR4* & 349,23 & 7,58 & $-23,83$ & 6,31 \\
\hline & & $-66,67$ & SP4* & $-1.692,54$ & t.n.* & $-261,62$ & - \\
\hline
\end{tabular}

Fonte: valores calculados pela autora com base nos dados dos apêndices 1 e 6

* taxa negativa

A variável preço da lenha, para o projeto $\mathrm{SP} 4 *$, é a que mais influência as estimativas obtidas tanto no cenário otimista qụanto pessimista. Com o aumento de $66,67 \%$ do preço da lenha o Valor Atual e a TIR obtidos para SP4* são, respectivamente, $170,01 \%$ e $55,83 \%$ maiores que os valores estimados para SP4. Com a redução do preço da lenha o Valor Atual obtido para SP4* é 261,62\% menor que o valor atual estimado para SP4.

Note que variações na produtividade florestal afetam significativamente a rentabilidade dos projetos aqui analisados. Dessa maneira, a preocupação com a qualidade das mudas utilizadas e com os cuidados básicos à condução do plantio com eucalipto devem ser constantes em programas de fomento florestal. 
Os resultados da tabela 33 demonstram que, mesmo em cenários pessimistas, os reflorestamentos com eucaliptos são economicamente viáveis. É importante ressaltar que a análise de sensibilidade é uma análise de risco parcial, mas que serve de subsídios para a análise de projetos em condições de risco.

\subsection{Análise de Risco pela simulação de Monte Carlo}

Assumindo a natureza estocástica dos projetos de reflorestamento com eucalipto, explicada principalmente pelas características inerentes à cultura, será utilizado o modelo de simulação desenvolvido por Hertz ${ }^{15}$, citado por Noronha (1988), e mais especificamente a técnica de Monte Carlo. No tópico 4.4 observou-se que alterações nas variáveis preço da lenha de eucalipto e, principalmente, na produtividade florestal afetam sobremaneira a rentabilidade dos projetos de reflorestamento em questão. Através da técnica de simulação Monte Carlo podem ser avaliados os efeitos que essas variações e outras, sob condições de risco, provocam à rentabilidade dos projetos aqui analisados.

A análise de risco oferece ao empreendedor uma estimativa numérica dos riscos do projeto. Dessa maneira, ela oferece a probabilidade de que determinado projeto produza certos valores especificados. Segundo Noronha (1988) dentre os métodos que utilizam probabilidade na análise de riscos o método de Monte Carlo é o mais simples do ponto de vista prático.

\subsubsection{Metodologia da Simulação de Monte Carlo}

Segundo Noronha (1988, p. 241), o método de simulação de Monte Carlo estabelece uma distribuição de probabilidade do indicador de rentabilidade escolhido (TIR, VA, etc) que servirá de base para a tomada de decisão. Para tanto, ele simula

\footnotetext{
${ }^{15}$ HERTZ, O B. Risk analysis in capital investment. Harvard Business Review, 42(1): 95-106, Jan./Fev. 1964.
} 
variáveis pré-selecionadas calculando o indicador de rentabilidade. É da repetição desse processo que resulta a distribuição de probabilidade do indicador de rentabilidade.

Primeiramente, atribuị-se à variável relevante selecionada uma distribuição de probabilidade. Segundo Takitane (1988, p. 41), isto é feito com base na experiência do empresário rural, do técnico e/ou pesquisador ou outro tomador de decisões. É comum o uso de estimativas subjetivas de probabilidades quando não se conhece a distribuição de probabilidade da variável selecionada. Dessa maneira, estimam-se os intervalos de variação da variável em estudo.

Posteriormente, são selecionados ao acaso um valor de cada variável a partir das distribuições de probabilidades estabelecidas. Estes vão formar um novo fluxo de caixa. A partir disso, são calculadas as medidas de rentabilidade necessárias (TIR, VA, RBC, etc.) sobre o fluxo de caixa simulado. O processo é repetido até que se obtenha a distribuição de freqüência dos indicadores de rentabilidade escolhidos.

No presente estudo as variáveis aleatórias selecionadas estão expostas no apêndice 8. Dada a falta de informações para determinar a forma de suas distribuições de probabilidade foi utilizada a distribuição triangular.

Segundo Takitane (1988, p.42), a distribuição triangular é definida pelo valor mais provável ou moda $(\mathrm{m})$ e pelos valores mínimos (a) e máximo (b) , assumidos pela variável $\mathrm{x}$. No presente trabalho a moda foi considerada como sendo igual ao valor médio obtido, ou seja: Prob $\{\mathrm{a} \leq \mathrm{x} \leq \mathrm{b}\}=1$.

Para promover a simulação, utilizou-se o software ALEAXPRJ desenvolvido por Azevedo Filho $(1988)^{16}$. Nele o usuário pode classificar as variáveis, quanto à sua natureza, em exógenas - definidas externamente ao processo que está sendo simulado, ou endógenas - definidas internamente ao processo simulado. Outra classificação das

\footnotetext{
${ }^{16}$ Para maiores instruções sobre a operacionalidade do programa veja Azevedo Filho, 1988g. ALEAXPRJ - Sistema para Simulação e Análise Econômica de Projetos em condições de Risco: Manual do Usuário. USP/PCP/CIAGRI - 43 p. Sobre o desenvolvimento do ALEAXPRJ leia Azevedo Filho, 1988.
} 
variáveis permitida pelo programa diz respeito aos períodos do projeto ${ }^{17}$. Assim, pode-se classificar as variáveis em temporais (definidas para cada período do projeto) ou constantes (única para todos os períodos do projeto).

\subsubsection{Estimativa dos indicadores de avaliação para os projetos selecionados - a análise de risco pela simulação de Monte Carlo}

O custo de oportunidade mínimo considerado para a análise em condição de risco dos projetos selecionados foi de $6 \%$ ao ano. Os resultados das simulações são apresentados em tabelas individuais para cada Estado. Em cada tabela tem-se a média dos valores obtidos na simulação, o desvio-padrão, o limite estabelecido para cada estimativa, a probabilidade da ocorrência de valores superiores ao limite estabelecido e o número de simulações que não foram bem sucedidas.

Utilizou-se como limite para cada estimativa os valores obtidos na análise determinista para cada projeto. Nos quadros H.2, H.3 e H.4 do apêndice 8 foram definidas as variáveis aleatórias consideradas, bem como seus valores mínimo, médio e máximo assumidos.

As estimativas obtidas pela simulação de Monte Carlo, no Estado do Paraná são apresentadas na tabela 34. Pelas estimativas obtidas para os indicadores de rentabilidade (veja a coluna "média"), constata-se que os projetos de reflorestamento no Estado são atrativos mesmo sob condições de risco. Por outro lado, os valores dos indicadores de rentabilidade em condições de risco são menos atrativos quando comparados com as estimativas da análise determinista (valores limites). Observe que, com exceção do CTA, o valor médio do indicador em condições de risco é menor do que o obtido na análise determinista.

\footnotetext{
${ }^{17}$ Da mesma forma o usuário conta com 5 tipos de distribuições de probabilidade para as variáveis exógenas: normal, triangular, inteira (2 valores), uniforme e spike (valor constante com probabilidade de $1.0)$.
} 
Nota-se que para os projetos que consideram o custo de aquisição da terra e das mudas a TIR é de 7,3\% na simulação de Monte Carlo, com desvio-padrão de 0,015 (ou seja, de 1,5 ponto percentual).

Tabela 34 - Indicadores de rentabilidade considerando análise de risco para o plantio de eucalipto no Estado do Paraná (custo de oportunidade de 6\%).

\begin{tabular}{lrrrrrr}
\hline \multicolumn{1}{c}{ Especificação } & Indicador & \multicolumn{1}{c}{ Média } & Desvio-padrão & \multicolumn{1}{c}{ Limite (L) } & P(I>L) & N.S \\
\hline Com doação de & TIR & 0,222 & 0,023 & 0,226 & 0,445 & 0 \\
mudas ao produtor & VA & 1293,516 & 179,518 & 1335,250 & 0,430 & 0 \\
rural e sem incluir & RBC & 2,301 & 0,216 & 2,440 & 0,245 & 0 \\
o custo de & PBS & 7,000 & 0,000 & 7,000 & 0,000 & 0 \\
aquisição da Terra & PBE & 7,000 & 0,000 & 7,000 & 0,000 & 0 \\
(PR1) & CTA & 999,777 & 55,900 & 925,830 & 0,915 & 0 \\
\hline Com aquisição de & TIR & 0,184 & 0,020 & 0,188 & 0,415 & 0 \\
mudas pelo & VA & 1159,380 & 182,006 & 1204,940 & 0,405 & 0 \\
produtor rural e & RBC & 2,032 & 0,196 & 2,140 & 0,320 & 0 \\
sem incluir o custo & PBS & 7,000 & 0,000 & 7,000 & 0,000 & 0 \\
de aquisição da & PBE & 7,000 & 0,000 & 7,000 & 0,000 & 0 \\
Terra (PR2) & CTA & 1131,691 & 70,321 & 1054,140 & 0,875 & 0 \\
\hline Com doação de & TIR & 0,079 & 0,015 & 0,077 & 0,495 & 0 \\
mudas ao produtor & VA & 391,548 & 272,844 & 410,340 & 0,485 & 0 \\
rural e com o & RBC & 1,190 & 0,150 & 1,180 & 0,505 & 0 \\
custo de aquisição & PBS & 12,845 & 3,041 & 14,000 & 0,025 & 0 \\
da terra (PR3) & PBE & 19,382 & 3,216 & 21,000 & 0,000 & 14 \\
& CTA & 2270,374 & 309,506 & 2233,360 & 0,545 & 0 \\
\hline Com aquisição de & TIR & 0,073 & 0,015 & 0,071 & 0,485 & 0 \\
mudas pelo & VA & 263,282 & 297,861 & 282,030 & 0,470 & 0 \\
produtor rural e & RBC & 1,126 & 0,147 & 1,120 & 0,460 & 0 \\
com o custo de & PBS & 13,615 & 2,736 & 14,000 & 0,050 & 0 \\
aquisição da terra & PBE & 19,812 & 2,956 & 21,000 & 0,000 & 35 \\
(PR4) & CTA & 2383,182 & 310,376 & 2361,670 & 0,540 & 0 \\
\hline Fonte: valora
\end{tabular}

Fonte: valores calculados pela autora por meio da simulação de Monte Carlo, considerando as informações do apêndice 8

No Estado de Minas Gerais, de acordo com as estimativas obtidas pelo método do Valor Atual e da TIR (tabela 35), os projetos de reflorestamento com eucalipto são mais atrativos mesmo quando se inclui riscos na análise. Por outro lado, o CTA em todos os projetos considerados mostrou-se superior àqueles obtidos na análise determinista, o que demonstra a necessidade de maiores recursos orçamentários ao produtor rural para proceder ao investimento.

Todas as simulações realizadas foram bem sucedidas. Apenas o projeto MG3 não apresentou PBE uma única vez (N.S.=1). 
Observa-se que em Minas Gerais a TIR para os projetos que incluem o custo de aquisição da terra varia entre $21 \%$ (projeto MG3) e $22,7 \%$ (projeto MG4), com desviopadrão de 0,05 e 0,046 , respectivamente.

Tabela 35 - Indicadores de rentabilidade considerando análise de risco para o plantio de eucalipto no Estado de Minas Gerais (custo de oportunidade de 6\%).

\begin{tabular}{|c|c|c|c|c|c|c|}
\hline Especificação & Indicador & Média & Desvio-padrão & Limite (L) & $\mathbf{P}(\mathbf{I}>\mathbf{L})$ & N.S \\
\hline \multirow{6}{*}{$\begin{array}{l}\text { Com compra da lenha de } \\
\text { eucalipto do } 1^{\circ} \text { corte pela } \\
\text { empresa financiadora, sem } \\
\text { incluir o custo da terra } \\
\text { (MG1) }\end{array}$} & TIR & 0,302 & 0,070 & 0,296 & 0,545 & $\overline{0}$ \\
\hline & VA & 2231,409 & 892,469 & 2275,640 & 0,485 & 0 \\
\hline & RBC & 1,556 & 0,238 & 1,620 & 0,375 & 0 \\
\hline & PBS & 7,000 & 0,000 & 7,000 & 0,000 & 0 \\
\hline & PBE & 7,000 & 0,000 & 7,000 & 0,000 & 0 \\
\hline & CTA & 4070,452 & 274,025 & 3665,730 & 0,940 & 0 \\
\hline \multirow{6}{*}{$\begin{array}{l}\text { Com compra da lenha de } \\
\text { eucalipto no } 1^{0} \text { e } 2^{0} \text { cortes } \\
\text { pela empresa financiadora, } \\
\text { sem incluir o custo da terra } \\
\text { (MG2) }\end{array}$} & $\overline{\text { TIR }}$ & 0,325 & 0,053 & 0,309 & 0,600 & $\overline{0}$ \\
\hline & VA & 3165,799 & 771,129 & 2913,580 & 0,595 & 0 \\
\hline & $\mathrm{RBC}$ & 1,781 & 0,209 & 1,790 & 0,480 & 0 \\
\hline & PBȘ & 7,000 & 0,000 & 7,000 & 0,000 & 0 \\
\hline & PBE & 7,000 & 0,000 & 7,000 & 0,000 & 0 \\
\hline & CTA & 4086,471 & 252,744 & 3665,730 & 0,945 & 0 \\
\hline \multirow{6}{*}{$\begin{array}{l}\text { Com compra da lenha de } \\
\text { eucalipto do 1 }{ }^{\circ} \text { corte pela } \\
\text { empresa financiadora, } \\
\text { incluindo o custo da terra } \\
\text { (MG3) }\end{array}$} & TIR & 0,210 & 0,050 & 0,201 & 0,560 & $\overline{0}$ \\
\hline & VA & 2037,868 & 800,378 & 1992,120 & 0,475 & 0 \\
\hline & RBC & 1,458 & 0,192 & 1,490 & 0,400 & 0 \\
\hline & PBS & 7,000 & 0,000 & 7,000 & 0,000 & 0 \\
\hline & PBE & 7,000 & 0,000 & 7,000 & 0,005 & 1 \\
\hline & CTA & 4500,407 & 270,546 & 4065,730 & 0,955 & 0 \\
\hline \multirow{6}{*}{$\begin{array}{l}\text { Com compra da lenha de } \\
\text { eucalipto no } 1^{\circ} \text { e } 2^{\circ} \text { cortes } \\
\text { pela empresa financiadora e } \\
\text { incluindo o custo da terra } \\
\text { (MG4) }\end{array}$} & TIR & 0,227 & 0,046 & 0,217 & 0,570 & $\overline{0}$ \\
\hline & VA & 2833,666 & 893,601 & 2631,24 & 0,580 & 0 \\
\hline & $\mathrm{RBC}$ & 1,638 & 0,212 & 1,650 & 0,465 & 0 \\
\hline & PBS & 7,000 & 0,000 & 7,000 & 0,000 & 0 \\
\hline & PBE & 7,105 & 0,853 & 7,000 & 0,015 & 0 \\
\hline & CTA & 4484,142 & 272,542 & 4065,73 & 0,940 & 0 \\
\hline
\end{tabular}

Fonte: valores calculados pela autora por meio da simulação de Monte Carlo, considerando as informações do apêndice 8

No Estado de São Paulo, de acordo com as estimativas obtidas (ver tabela 36) os projetos de reflorestamento considerados são atrativos mesmo quando analisados sob condições de risco. De modo geral, os valores da TIR e do VA são próximos em condições de risco e na análise determinista. Observa-se também que o período de recuperação do capital, para os projetos que consideram o custo da terra, é bastante superior àqueles encontrados na análise determinista.

Para o caso onde há aquisição de terra e de mudas, a TIR em condições de risco foi estimada em 9,4, com desvio-padrão de 0,025 . 
Tabela 36 - Indicadores de rentabilidade considerando análise de risco para plantio de eucalipto no Estado de São Paulo (custo de oportunidade de 6\%).

\begin{tabular}{|c|c|c|c|c|c|c|}
\hline Especificação & Indicador & Média & Desvio-padrão & Limite (L) & $P(I>L)$ & N.S \\
\hline \multirow{6}{*}{$\begin{array}{l}\text { Com doação de mudas } \\
\text { ao produtor rural, sem } \\
\text { incluir o custo da terra } \\
\text { (SP1) }\end{array}$} & TIR & 0,298 & 0,054 & 0,302 & 0,480 & $\overline{0}$ \\
\hline & VA & 2311,082 & 641,166 & 2347,770 & 0,475 & 0 \\
\hline & RBC & 3,088 & 0,597 & 3,250 & 0,375 & 0 \\
\hline & PBS & 7,000 & 0,000 & 7,000 & 0,000 & 0 \\
\hline & PBE & 7,105 & 0,000 & 7,000 & 0,015 & 0 \\
\hline & CTA & 1116,219 & 77,835 & 1044,090 & 0,800 & 0 \\
\hline \multirow{6}{*}{$\begin{array}{l}\text { Com aquisição de mudas } \\
\text { pelo produtor rural, sem } \\
\text { incluir o custo da terra } \\
\text { (SP2) }\end{array}$} & TIR & 0,254 & 0,051 & 0,251 & 0,535 & 0 \\
\hline & VA & 2219,724 & 648,149 & 2201,130 & 0,510 & 0 \\
\hline & $\mathrm{RBC}$ & 2,771 & 0,546 & 2,850 & 0,465 & 0 \\
\hline & PBS & 7,000 & 0,495 & 7,000 & 0,000 & 0 \\
\hline & PBE & 7,070 & 0,982 & 7,000 & 0,010 & 0 \\
\hline & CTA & 1264,155 & 78,818 & 1190,730 & 0,780 & 0 \\
\hline \multirow{6}{*}{$\begin{array}{l}\text { Com doação de mudas } \\
\text { ao produtor rural, } \\
\text { incluindo o custo da terra } \\
\text { (SP3) }\end{array}$} & TIR & 0,097 & 0,036 & 0,100 & 0,460 & 0 \\
\hline & VA & 1122,910 & 2325,831 & 1193,860 & 0,500 & 0 \\
\hline & RBC & 1,406 & 0,392 & 1,450 & 0,450 & 0 \\
\hline & PBS & 10,745 & 5,058 & 7,000 & 0,495 & 0 \\
\hline & PBE & 15,686 & 5,777 & 14,000 & 0,377 & 9 \\
\hline & CTA & 2866,390 & 3150,830 & 2678,870 & 0,665 & 0 \\
\hline \multirow{6}{*}{$\begin{array}{l}\text { Com aquisição de mudas } \\
\text { pelo produtor rural, } \\
\text { incluindo o custo da terra } \\
\text { (SP4) }\end{array}$} & TIR & 0,094 & 0,025 & 0,093 & 0,490 & 0 \\
\hline & VA & 1040,721 & 718,803 & 1047,220 & 0,500 & 0 \\
\hline & $\mathrm{RBC}$ & 1,370 & 0,276 & 1,370 & 0,475 & 0 \\
\hline & PBS & 10,815 & 4,314 & 7,000 & 0,480 & 0 \\
\hline & PBE & 15,816 & 4,991 & 14,000 & 0,416 & 15 \\
\hline & CTA & 2990,697 & 405,579 & 2825,510 & 0,640 & 0 \\
\hline
\end{tabular}

Fonte: valores calculados pela autora por meio da simulação de Monte Carlo e considerando as informações do apêndice 8

Comparando os resultados obtidos nas tabelas 34 a 36 com o de outros projetos de agricultura permanente ou de silvicultura (tabela 37 ) constata-se que os projetos de reflorestamento em pequena escala com eucalipto apresentam, de modo geral, maior TIR e menor período de recuperação do capital.

Dos resultados das análises de risco (análise de sensibilidade e Simulação de Monte Carlo) pode-se afirmar que a doação de mudas e insumos pelo poder público ao produtor rural reduz fortemente os custos incorridos no cultivo do eucalipto, elevando substancialmente a lucratividade dos projetos. Além disso, sem incorrer em despesas com mudas o pequeno e médio produtor tem a oportunidade de dispender melhores cuidados ao plantio, influenciando a produtividade florestal a ser alcançada. Como visto anteriormente, a produtividade florestal é uma variável crucial na melhoria da rentabilidade do projeto. (ver análise de sensibilidade tópico 4.2). 
Tabela 37 - Estimativa de alguns indicadores de rentabilidade considerando análise de risco para projetos na agricultura - sem incluir o custo da terra

\begin{tabular}{lccc}
\hline \multicolumn{1}{c}{ Projeto } & $\begin{array}{c}\text { Taxa Interna de } \\
\text { Retorno estimada }\end{array}$ & $\begin{array}{c}\text { "Payback } \\
\text { Simples" }\end{array}$ & $\begin{array}{c}\text { "Payback } \\
\text { Econômico" }\end{array}$ \\
\hline Pomar de Laranjeira (com declínio) & 0,180 & 10,484 & 0,180 \\
Pomar de Laranjeira (sem declínio) & 0,192 & 10,406 & n.d.* \\
Seringal & 0,196 & 13,535 & n.d.* \\
Seringal & 0,144 & 18,570 & 0,144 \\
Araruva (com aquisição de mudas) & 0,169 & 25,000 & 25,000 \\
Araruva (com doação de mudas) & 0,222 & 18,655 & 25,000 \\
Pau-marfim (com aquisição de mudas) & 0,152 & 25,000 & 25,000 \\
Pau-marfim (com doação de mudas) & 0,192 & 23,325 & 25,000 \\
Pinheiro-Brasileiro (com aquisição de mudas) & 0,170 & 25,000 & 25,000 \\
Pinheiro-Brasileiro (com doação de mudas) & 0,197 & 24,840 & 25,000 \\
\hline
\end{tabular}

Fonte: Azevedo Filho (1988), Takitane (1988) e Machado (2000)

* dados não disponíveis. 


\section{CONCLUSÕES}

O trabalho analisou a evolução do reflorestamento em pequenos e médios imóveis rurais, avaliando os impactos de programas públicos e privados sobre esses reflorestamentos. Para tanto, tomou-se como casos em estudo os Estados Minas Gerais, São Paulo e Paraná.

Primeiramente, identificou-se os principais programas realizados nos Estados em análise e voltados ao reflorestamento em pequenas e médias propriedades rurais. Procurou-se distinguir os programas realizados pelos governos (federal e estaduais), daqueles realizados pela iniciativa privada. Posteriormente, procedeu-se a análise da evolução das áreas reflorestadas anualmente e de seus estoques em certos momentos nos Estados de Minas Gerais, São Paulo e Paraná, comparando os resultados alcançados com os programas considerados anteriormente. A terceira etapa do trabalho buscou verificar a viabilidade econômica do reflorestamento, sob a ótica do produtor rural, e como ela é afetada pelo tipo de estímulo dado nos programas anteriormente considerados. Foi considerado apenas o plantio de eucalipto dada sua maior freqüência nos programas voltados ao fomento florestal. A análise econômica dos projetos de reflorestamento com eucalipto foi realizada sob condições estritamente deterministas, bem como sob condições de risco. A análise sob condições de risco foi realizada em duas etapas: a análise de sensibilidade e a simulação de Monte Carlo.

Averiguou-se a existência de três experiências distintas. De um lado tem-se o Estado de São Paulo, que fundamentou a política de estímulo ao reflorestamento em pequenos e médios imóveis rurais em organizações civis (as Associações de Recuperação Florestal) e na iniciativa privada. Por outro lado, tem-se o Estado do 
Paraná onde as atividades voltadas ao estímulo ao reflorestamento em pequenos e médios imóveis rurais são centralizadas no poder público estadual. Assim, o Governo Estadual é quem promove o engajamento de diferentes agentes (produtores rurais, prefeituras municipais, entre outros) nas atividades florestais. Por fim, o mecanismo utilizado em Minas Gerais envolve tanto o Governo Estadual quanto à iniciativa privada no fomento florestal.

Constatou-se que nos Estados de Minas Gerais e Paraná o estoque de florestas plantadas em pequenas e médias propriedades rurais apresenta crescimento entre os anos de 1970 e 1995. Por outro lado, em São Paulo existe o decréscimo de áreas ocupadas com florestas plantadas neste mesmo período.

Em Minas Gerais, a atuação conjunta entre Governo Estadual e iniciativa privada está gerando resultados positivos no que diz respeito ao aumento das áreas reflorestadas. Conclui-se que os programas públicos estaduais implementados no Estado, principalmente na década de 90 , estão contribuindo para a crescente inclusão do pequeno e médio produtor rural no processo de reflorestamento.

O Estado de São Paulo, por meio das associações de recuperação florestal, buscou a integração dos pequenos e médios produtores rurais no processo de reposição florestal. Os resultados alcançados pelas ARFs, em termos de área reflorestada junto a pequenas e médias propriedades rurais, são significativos. Entretanto, constatou-se que a falta de atuação direta do governo estadual no processo de reflorestamento junto ao produtor rural em São Paulo vêm limitando o aumento de áreas reflorestadas.

No Estado do Paraná, mesmo com uma grande centralização, pelo Governo Estadual, das atividades voltadas ao fomento florestal, está ocorrendo o aumento das áreas reflorestadas junto a pequenos e médios imóveis rurais.

Constatou-se, assim, diferenças marcantes nas políticas florestais implementadas nos três Estados. Observou-se que nos Estados do Paraná e Minas Gerais a existência de uma Lei Florestal Estadual e de políticas florestais bem elaboradas são fundamentais no processo de reflorestamento. Isto porque permitem o delineamento do raio de atuação da 
iniciativa privada que, associada às atividades e responsabilidades do poder público sobre a questão florestal, parece crucial para os resultados alcançados em termos de área reflorestada nestes dois Estados.

No Estado de São Paulo, todavia, a coordenação das atividades do setor florestal está disseminada entre os diversos agentes da iniciativa privada. Não existe no Estado uma Lei Florestal Estadual, o que culmina na ausência de programas públicos sistemáticos que integrem o pequeno e médio produtor rural ao reflorestamento.

Com o intuito de analisar a viabilidade do reflorestamento com eucalipto em pequenos e médios imóveis e verificar como os programas estaduais afetam essa rentabilidade, observou-se que, em geral, é fato comum a doação de mudas como meio de incentivo à atividade. Utilizou-se dessa informação para estimar a variação na rentabilidade de projetos de reflorestamento junto a pequenos e médios imóveis rurais considerando a doação ou compra de mudas. Uma das limitações dessa análise é que as estimativas obtidas não se referem a todas as regiões dos Estados em análise, mas sim, a certas regiões de expansão do fomento florestal em pequenos e médios imóveis rurais. Além disso, é importante ressaltar que as produtividades, formas de pagamento e subsídios implícitos em cada caso considerado são distintos.

Em condições estritamente deterministas ou sob condições de risco os projetos de reflorestamentos analisados foram considerados economicamente viáveis. Considerando a compra de terra e de mudas pelo produtor rural, as estimativas da TIR pela simulação de Monte Carlo ficam ao redor de 7\% para o Paraná e de 9\% em São Paulo. Em Minas Gerais a TIR foi calculada sem o custo das mudas e foi de $21 \%$ a $23 \%$, dependendo do que a empresa fomentadora compra de madeira.

Em condições deterministas, a doação de mudas foi responsável pelo aumento de 8,3\% na rentabilidade dos projetos no Estado do Paraná e de 6,8\% no Estado de São Paulo. No Estado de Minas Gerais, a doação de mudas e insumos foi responsável pelo aumento de $52,19 \%$ e $43,88 \%$ na rentabilidade dos projetos MG3 e MG4 considerados. 
Constata-se, portanto, que o incentivo governamental ao reflorestamento através de doação de mudas e insumos proporciona menores custos de implantação dos projetos e dessa maneira possibilita maiores ganhos ao produtor rural.

No entanto, é necessário proporcionar ao produtor rural melhores condições de comercialização dos produtos florestais obtidos. Assim, é importante a integração entre os interesses do produtor e os interesses dos segmentos consumidores da matéria-prima florestal produzida. A implantação de políticas florestais estaduais devem ser voltadas ao atendimento dessas necessidades.

Por fim, ressalta-se que a avaliação realizada dos projetos de reflorestamento não considerou os benefícios sociais advindos com o reflorestamento. Além disso, considerou-se apenas o sistema de prođução para obtenção de um único produto. De outro lado, o produtor rural pode obter outras receitas fazendo uso múltiplo da floresta (retirada de lenha, toras, postes, etc) além da possibilidade de aliar a cultura do eucalipto a outras culturas, utilizando-se, assim, de sistemas agrossilviculturais ou ainda silvipastoris, contribuindo para o aumento da rentabilidade do investimento.

Novas linhas de pesquisa que considerem a avaliação social de projetos de reflorestamento em pequenas propriedades são importantes, assim como trabalhos que analisem a viabilidade econômica de sistemas silvipastoris e agrossilvipastoris. Os resultados dessas pesquisas podem permitir melhorias nos programas de fomento florestal em pequenos e médios imóveis rurais. 


\section{REFERÊNCIAS BIBLIOGRÁFICAS}

ASSOCIAÇÃO BRASILEIRA DE CELULOSE E PAPEL. Statistical Report. São Paulo. BRACELPA, $1998.60 \mathrm{p}$.

ASSOCIAÇÃo BRASILEIRA DE FLORESTAS RENOVÁVEIS. Anuário Estatístico. Belo Horizonte: ABRACAVE. (vários números).

ASSOCIAÇÃO BRASILEIṚA DE FLORESTAS RENOVÁVEIS. Anuário. http://www.abracave.com.br (jun. 2000).

ALBUQUERQUE. Avaliação econômica de alternativas de financiamento da produção florestal no Estado de Minas Gerais. Viçosa, 1993. 102p. Dissertação (mestrado). Universidade Federal de Viçosa.

ANDREWS, C.W. Associações de Recuperação Florestal e a questão Ambiental Regional. In: Seminário sobre aspectos econômicos, sociais e ambientais do fomento florestal. Belo Horizonte, 1990. Anais. Viçosa: SIF, 1991. p. 51-63.96 p.

ANDREWS, C.W. Avaliação do desempenho das associações de recuperação florestal no estado de São Paulo (Brasil) visando a uma política de reposição florestal estadual. 1991, p. 79 a 95.

ANGELO, H. Cobertura Florestal na pequena propriedade rural: uma alternativa para o desenvolvimento. Brasil Florestal, n. 61, p. 324-347, jul/ago/set. 1987.

APROMAC. Histórico da política florestal paranaense. http://www.apromac.org.br (maio. 1998).

ARIENTE, W.L. Os investimentos em recursos florestais: um estudo do uso de despesa tributária como instrumento de política setorial. Rio de Janeiro, 1983. 200 p. Dissertação (mestrado). Pontifícia Universidade Católica.

ASSIS, J.B.; SILVA, E.; ARAÚJO, J.C.A. Desempenho do reflorestamento em pequenos e médios imóveis rurais na Zona da Mata. Informe Agropecuário, v. 12, n. 141, p. 90-4, 1986. 
AZEVEDO FILHO, A.J.B.V. Elementos de matemática financeira e análise de projetos de investimentos. Série didática. Departamento de Economia e Sociologia Rural. ESALQ/USP. Piracicaba, n. 109, p. 1-93. 1995.

AZEVEDO FILHO, A.J.B.V. DETERPRJ : Sistema para análise econômica de projetos em condições deterministas. Manual do Usuário. Versão 1.00. USP/CIAGRI. 1988. 22 p.

AZEVEDO FILHO, A.J.B.V. Análise econômica de projetos: "software" para situações deterministas e de risco envolvendo simulação. Piracicaba, 1988. 127 p. Dissertação (mestrado) - Escola Superior de Agricultura "Luiz de Queiroz", Universidade de São Paulo.

BACHA, C.J.C. Gestão Florestal no Paraná. In: LOPES, I.V. et alii (org.). Gestão Ambiental no Brasil : experiência e sucesso. Rio de Janeiro: Fundação Getúlio Vargas. 1996. p. 155182.

BACHA, C.J.C. Análise custo-benefício dos programas federais de incentivo ao reflorestamento no Brasil. Piracicaba: ESALQ/USP/CNPq, 1995. 93 p. (Relatório de pesquisa).

BACHA, C.J.C. As políticas florestais estaduais: os casos de Minas Gerais, Rio de Janeiro, São Paulo e Paraná. Piracicaba: ESALQ/USP/CNPq, 1998. 88 p. (Relatório de pesquisa).

BANCO CENTRAL DO BRASIL. Manual de normas e instruções crédito rural.// Resolução no 2.164 de 19 de junho de 1995: Crédito Rural, Disposições Preliminares, Beneficiários.

BERGAMASCO, A.; BERGAMASCO, S.M.P.P. O Programa de reflorestamento de pequenos e médios imóveis rurais (REPEMIR) no Estado de São Paulo: uma avaliação Preliminar. In: ENCONTRO BRASILEIRO DE ECONOMIA FLORESTAL, 1, Curitiba, 1988. Anais. Curitiba: EMBRAPA/CNPF, 1988. v. 2, p. 79-98.

CAPP FILHO, M. Avaliação econômica do reflorestamento no Estado de Minas Gerais. Viçosa, 1976. 106 p. Dissertação (Mestrado). Universidade Federal de Viçosa.

CARVALHO, J.C.; ARAƯJO, J.C.A. A extensão na condução da política florestal mineira. In: ENCONTRO BRASILEIRO DE EXTENSÃO FLORESTAL, 1, Piracicaba, 1985. p. 5-16.

CARVALHO, J.C. Gestão Florèstal em Minas Gerais. In: LOPES, I.V. et alii (org.). Gestão Ambiental no Brasil : experiência e sucesso. Rio de Janeiro: Fundação Getúlio Vargas, 1996. p. $127-154$. 
CARVALHO, J.C. Sistema e Experiências de Uso Sustentável de Florestas: o caso de Minas Gerais. Rio de Janeiro. 1995. 42 p. (Relatório de Pesquisa Banco Mundial/Fundação Getúlio Vargas).

CASTRO FILHO, F.P. Política de Fomento Florestal no Estado de Minas Gerais. In: SEMINÁRIO SOBRE ASPECTOS ECONÔMICOS, SOCIAIS E AMBIENTAIS DE FOMENTO FLORESTAL, Belo Horizonte, 1990. Anais. Viçosa : Sociedade de Investigações Florestais - SIF, 1991. p. 18-28.

CESP. Recomposição de matas nativas pela CESP. In: CURSO RECUPERAÇÃO DE ÁREAS DEGRADADAS, Curitiba, 1993. Anais. Curitiba: UFPR/FUPEF, 1993. v. 2, p. 322-31.

CESP. Viveiros e Reflorestamentos. / CESP. São Paulo. 1999. 27 p. (Série Divulgação e Informação, 235).

DOSSA, D.; COUTO, J.A.; RODIGHERI, H.; HOEFLICH, V.A. Aplicativo com análise de rentabilidade para sistemas de produção de florestas cultivadas e de grãos. Série Documentos - EMBRAPA/CNPF - Centro Nacional de Pesquisa de Florestas, n. 39, ago. 2000 .

ELIAS, R. Reflorestamento. In: Lombardi Neto, F.; Drugowich, M. I. (Coord.). Microbacias Hidrográficas. São Paulo: PEMBH, 1994. v. 1, p. 111-116.

FERNANDES, O.R. O Plano de Fomento Florestal da CESP. In: Encontro Brasileiro de Extensão Florestal, 1, Piracicaba, 1985. Anais. Piracicaba: IPEF/ESALQ, 1985. p. 51 - 63.

FERRETTI, A.R. O fomento florestal da CESP / Porto Primavera com propriedades da região de Assis - SP. Piracicaba, 2000. 156 p. Dissertação (mestrado) - Escola Superior de Agricultura "Luiz de Queiroz", Universidade de São Paulo.

FNP Consultoria \& Comércio. Agrianual: anuário da agricultura brasileira. São Paulo, 2000. p. 89-104: mecanização.

FUNDAÇÃO INSTITUTO BRASILEIRO DE GEOGRAFIA E ESTATÍSTICA. Censo Agropecuário do Brasil. Rio de Janeiro: IBGE, 1970, 1975, 1980, 1985, 1995/1996.

GITMAN, L.J. Princípios de Administração Financeira. 3.ed. São Paulo: Harbra, 1984. 781 p. 
GONÇALVES, W.; VENTURA, V.J. Uma política para manutenção da biodiversidade no Estado de São Paulo. In: Revista do Instituto Florestal, São Paulo, v. 4, mar. 1992. p. 10631066.

INSTITUTO DE ECONOMIA APLICADA. Informações econômicas. São Paulo, 1999. p. 8196 : indicadores.

INSTITUTO AMBIENTAL DO PARANÁ. Base de dados. http:// www.pr.gov.br/iap/ (maio. 2000).

INSTITUTO BRASILEIRO DE DESENVOLVIMENTO FLORESTAL ; SECRETARIA DO ESTADO DA AGRICULTURA DO PARANÁ. Programa de Reflorestamento em Pequenos e Médios Imóveis Rurais - REPEMIR. Brasília: IBDF/SEAP, 1980. 20 p.

INSTITUTO BRASILEIRO DE DESENVOLVIMENTO FLORESTAL; DEPARTAMENTO DE ECONOMIA FLORESTAL. Programa de reflorestamento em pequenos e médios imóveis rurais - REPEMIR. Brasília. IBDF/DEF, 1980. 25 p.

INSTITUTO ESTADUAL DE FLORESTAS. Fomento Florestal. www. ief.mg.gov.br/ddfs/ (maio. 2000).

KAGEYAMA, P.Y.; CESP - Equipe Técnica do Departamento de Meio Ambiente e Recursos Naturais. Recomposição da vegetação com espécies arbóreas nativas em reservatórios de usinas hidrelétricas da CESP. Série Técnica IPEF, v. 8, n. 25, p. 1-43, set. 1992.

LIMA, P.C.F. Espécies potenciais para reflorestamento em regiões semi-áridas. Silvicultura. Ano X, n. 37, p. 28-32, 1985.

MACHADO, J.A.R. A viabilidade econômica dos reflorestamentos com essências nativas brasileiras para a produção de toras - o caso do Estado de São Paulo. Piracicaba, 2000. 186 p. Dissertação (mestrado) - Escola Superior de Agricultura "Luiz de Queiroz", Universidade de São Paulo.

MAIA, F.X. Programa Fazendeiro Florestal - Experiência CAF/CSBM. Companhia Agrícola Santa Bárbara. João Monlevade: 3 p. / 198 /

MARTIM, N.B. Manejo de microbacias: o caso do Paraná - Rural. In: LOPES, I.V. et alii (org.). Gestão Ambiental no Brasil : experiência e sucesso. Rio de Janeiro: Fundação Getúlio Vargas. 1996. p. 239-264. 
MIALHE, L.G. Manual de mecanização agrícola. São Paulo: Agronómica ceres, 1974. 301 p.

NEVES, A.R. Avaliação Sócio-econômica de um programa de reflorestamento na região de carbonita, Vale do Jequitinhonha, MG. Viçosa, 1979. 82 p. Dissertação (Mestrado) Universidade Federal de Viçosa.

NEVES, J.C. O fomento florestal e seus impactos a nível de meio ambiente. In: ENCONTRO TÉCNICO FLORESTAL, 6, Belo Horizonte,1994. Anais. Belo Horizonte: ABRACAVE, 1994. Não paginado.

NORONHA, J.F. Projetos Agropecuários: administração financeira, orçamento e viabilidade econômica. 2. ed. São Paulo: Atlas, 1987. 269 p.

PARANÁ. Secretaria de Estado do Meio Ambiente e dos Recursos Hídricos. Instituto Ambiental do Paraná. Diretoria de Desenvolvimento Florestal. Estratégias para o desenvolvimento florestal no Estado do Paraná : Paraná Florestal. Paraná, 1995. 15 p.

PARANÁ. Secretaria de Estado do Meio Ambiente e dos Recursos Hídricos. Instituto Ambiental do Paraná. Diretoria de Desenvolvimento Florestal. Gestão de Resultados. Paraná, 1998. $26 \mathrm{p}$.

PASICOLAN, P.N.; HAES, H.A.U.; SAJSE, P.E. Farm forestry: na alternative to governmentdriven reforestation in the Philippines. Forestry Ecology and Management, n. 99. p. 261$274,1997$.

REZENDE, J.L.P. Avaliação dos possíveis impactos econômicos da atividade reflorestamento em 3 municípios da Zona da Mata, MG. Viçosa, 1975. 59 p. Dissertação (Mestrado) Universidade Federal de Viçosa.

RODIGHERI, H.R.; PINTO, A.F. Viabilidade econômica do programa de expansão da eucaliptocultura no norte pioneiro do Estado do Paraná. Circular Técnica EMBRAPA/CNPF - Centro Nacional de Pesquisa de Florestas, n. 27, p. 9-25, 1997.

RODRIGUEZ, L.C.E.; RODRIGUES,F.; BUENO,A.R.S. Rotações de Eucaliptos mais longas: análise volumétrica e econômica. Sciencia Forestalis, n. 51, p. 15-28, jun.1997.

SANTOS, A.J. Indústria de Madeiras serradas no Estado do Paraná. In: ENCONTRO BRASILEIRO DE ECONOMIA FLORESTAL, 1, Curitiba, 1988. Anais. Curitiba: EMBRAPA/CNPF, 1988. v. 2, p. 575-610. 
SILVA, J.R. Matarazzo e o Fomento Florestal. / Apresentado ao Seminário Fomento /Fazendeiro Florestal. Sete Lagoas-MG, 1988. $10 \mathrm{p}$.

TAKITANE, I.C. Custo de produção da borracha e análise da rentabilidade em condições de risco no planalto paulista; SP e no triângulo mineiro, MG. Piracicaba, 1988. 119 p. Dissertação (mestrado) - Escola Superior de Agricultura "Luiz de Queiroz", Universidade de São Paulo.

WORLD BANK. Minas Gerais Forestry Development Project (loan 2895-BR). Document of the World Bank. May, 1997.60 p.

YAMAZOE, G; BERGAMASCO, A.; ZANATTO, A.C.S.; MONTEIRO, C.H.B.; CARDOSO, J. L.; BUCCI, L.A.; VILAS BOAS, O.; ROSA, P.R.R. da. Avaliação do Programa de Reflorestamento de Pequenos e Médios Imóveis Rurais no Estado de São Paulo REPEMIR. São Paulo: Governo do Estado de São Paulo. Secretaria de Estado do Meio Ambiente. Coordenadoria da Pesquisa de Recursos Naturais. Instituto Florestal, 1988. 23 p. 
Apêndice 1 - Fluxo de caixa dos projetos analisados 
Tabela A.1 - Fluxo de caixa do projeto de plantio de 1 ha de eucalipto sem incluir o custo da terra e com doação de mudas ao produtor rural no Estado de São Paulo valores expressos em reais (R\$) de novembro de 1999 - Projeto SP1.

\begin{tabular}{|c|c|c|c|}
\hline ANOS & BENEFICIOS & CUSTOS & FLUXO LİQUIDO \\
\hline 0 & 0 & 288,17 & $-288,17$ \\
\hline 1 & 0 & 62,76 & $-62,76$ \\
\hline 2 & 0 & 52,69 & $-52,69$ \\
\hline 3 & 0 & 42,62 & $-42,62$ \\
\hline 4 & 0 & 42,62 & $-42,62$ \\
\hline 5 & 0 & 42,62 & $-42,62$ \\
\hline 6 & 0 & 42,62 & $-42,62$ \\
\hline 7 & $2.625,00$ & 204,28 & $2.420,72$ \\
\hline 8 & 0 & 42,62 & $-42,62$ \\
\hline 9 & 0 & 42,62 & $-42,62$ \\
\hline 10 & 0 & 42,62 & $-42,62$ \\
\hline 11 & 0 & 42,62 & $-42,62$ \\
\hline 12 & 0 & 42,62 & $-42,62$ \\
\hline 13 & $\cdot 0$ & 42,62 & $-42,62$ \\
\hline 14 & $2.325,00$ & 204,28 & $2.120,72$ \\
\hline 15 & 0 & 42,62 & $-42,62$ \\
\hline 16 & 0 & 42,62 & $-42,62$ \\
\hline 17 & 0 & 42,62 & $-42,62$ \\
\hline 18 & 0 & 42,62 & $-42,62$ \\
\hline 19 & 0 & 42,62 & $-42,62$ \\
\hline 20 & 0 & 42,62 & $-42,62$ \\
\hline 21 & $2.100,00$ & 204,28 & $1.895,72$ \\
\hline
\end{tabular}

Fonte: Apêndice 2 
Tabela A.2 - Fluxo de caixa do projeto de plantio de 1 ha de eucalipto sem incluir o custo da terra e com aquisição de mudas pelo produtor rural no Estado de São Paulo valores expressos em reais (R\$) de novembro de 1999 - Projeto SP2.

\begin{tabular}{|c|c|c|c|}
\hline ANOS & BENEFICIOS & CUSTOS & FLUXO LIQUIDO \\
\hline 0 & 0 & 434,81 & $-434,81$ \\
\hline 1 & 0 & 62,76 & $-62,76$ \\
\hline 2 & 0 & 52,69 & $-52,69$ \\
\hline 3 & 0 & 42,62 & $-42,62$ \\
\hline 4 & 0 & 42,62 & $-42,62$ \\
\hline 5 & 0 & 42,62 & $-42,62$ \\
\hline 6 & 0 & 42,62 & $-42,62$ \\
\hline 7 & $2: 625,00$ & 204,28 & $2.420,72$ \\
\hline 8 & 0 & 42,62 & $-42,62$ \\
\hline 9 & 0 & 42,62 & $-42,62$ \\
\hline 10 & 0 & 42,62 & $-42,62$ \\
\hline 11 & 0 & 42,62 & $-42,62$ \\
\hline 12 & 0 & 42,62 & $-42,62$ \\
\hline 13 & 0 & 42,62 & $-42,62$ \\
\hline 14 & $2.325,00$ & 204,28 & $2.120,72$ \\
\hline 15 & 0 & 42,62 & $-42,62$ \\
\hline 16 & 0 & 42,62 & $-42,62$ \\
\hline 17 & 0 & 42,62 & $-42,62$ \\
\hline 18 & 0 & 42,62 & $-42,62$ \\
\hline 19 & 0 & 42,62 & $-42,62$ \\
\hline 20 & 0 & 42,62 & $-42,62$ \\
\hline 21 & $2.100,00$ & 204,28 & $1.895,72$ \\
\hline
\end{tabular}

Fonte: Apêndice 2 
Tabela A.3 - Fluxo de caixa do projeto de plantio de 1 ha de eucalipto considerando o custo da terra para implantação do plantio e a doação de mudas ao produtor rural no Estado de São Paulo - valores expressos em reais (R\$) de novembro de 1999 - Projeto SP3.

\begin{tabular}{|c|c|c|c|}
\hline ANOS & BENEFFICIOS & CUSTOS & FLUXO LIQQUIDO \\
\hline 0 & 0 & 1922,95 & $-1922,95$ \\
\hline 1 & 0 & 62,76 & $-62,76$ \\
\hline 2 & 0 & 52,69 & $-52,69$ \\
\hline 3 & 0 & 42,62 & $-42,62$ \\
\hline 4 & 0 & 42,62 & $-42,62$ \\
\hline 5 & 0 & 42,62 & $-42,62$ \\
\hline 6 & 0 & 42,62 & $-42,62$ \\
\hline 7 & $2.625,00$ & 204,28 & $2 . \dot{4} 20,72$ \\
\hline 8 & 0 & 42,62 & $-42,62$ \\
\hline 9 & 0 & 42,62 & $-42,62$ \\
\hline 10 & 0 & 42,62 & $-42,62$ \\
\hline 11 & 0 & 42,62 & $-42,62$ \\
\hline 12 & 0 & 42,62 & $-42,62$ \\
\hline 13 & 0 & 42,62 & $-42,62$ \\
\hline 14 & $2.325,00$ & 204,28 & $2.120,72$ \\
\hline 15 & 0 & 42,62 & $-42,62$ \\
\hline 16 & 0 & 42,62 & $-42,62$ \\
\hline 17 & 0 & 42,62 & $-42,62$ \\
\hline 18 & 0 & 42,62 & $-42,62$ \\
\hline 19 & 0 & 42,62 & $-42,62$ \\
\hline 20 & 0 & 42,62 & $-42,62$ \\
\hline 21 & $3.734,78$ & 204,28 & $3.530,50$ \\
\hline
\end{tabular}

Fonte: Apêndice 2 
Tabela A.4 - Fluxo de caixa do projeto de plantio de 1 ha de eucalipto considerando o custo da terra para implantação do plantio e a aquisição de mudas pelo produtor rural no Estado de São Paulo - valores expressos em reais (R\$) de novembro de 1999 - Projeto SP4.

\begin{tabular}{|c|c|c|c|}
\hline ANOS & BENEFICIOS & CUSTOS & FLUXO LIQUUIDO \\
\hline 0 & 0 & $2.069,59$ & $-2.069,59$ \\
\hline 1 & 0 & 62,76 & $-62,76$ \\
\hline 2 & 0 & 52,69 & $-52,69$ \\
\hline 3 & 0 & 42,62 & $-42,62$ \\
\hline 4 & 0 & 42,62 & $-42,62$ \\
\hline 5 & 0 & 42,62 & $-42,62$ \\
\hline 6 & $\cdot 0$ & 42,62 & $-42,62$ \\
\hline 7 & $2.625,00$ & 204,28 & $2.420,72$ \\
\hline 8 & 0 & 42,62 & $-42,62$ \\
\hline 9 & 0 & 42,62 & $-42,62$ \\
\hline 10 & 0 & 42,62 & $-42,62$ \\
\hline 11 & 0 & 42,62 & $-42,62$ \\
\hline 12 & 0 & 42,62 & $-42,62$ \\
\hline 13 & 0 & 42,62 & $-42,62$ \\
\hline 14 & $2.325,00$ & 204,28 & $2.120,72$ \\
\hline 15 & 0 & 42,62 & $-42,62$ \\
\hline 16 & 0 & 42,62 & $-42,62$ \\
\hline 17 & 0 & 42,62 & $-42,62$ \\
\hline 18 & 0 & 42,62 & $-42,62$ \\
\hline 19 & 0 & 42,62 & $-42,62$ \\
\hline 20 & 0 & 42,62 & $-42,62$ \\
\hline 21 & $3.734,78$ & 204,28 & $3.530,50$ \\
\hline
\end{tabular}

Fonte: Apêndice 2 
Tabela A.5 - Fluxo de caixa do projeto de plantio de 1 ha de eucalipto em associação empresa-fazendeiro florestal, considerando a compra de $93,75 \%$ da madeira do $1^{\circ}$ corte pela empresa financiadora no Estado de Minas Gerais e não incluindo o custo da terra valores expressos em reais (R\$) de novembro de 1999 - Projeto MG1.

\begin{tabular}{cccc}
\hline ANOS & BENEFICIOS & CUSTOS & FLUXO LIQUIDO \\
\hline 0 & 0 & 337,40 & $-337,40$ \\
1 & 0 & 146,85 & $-146,85$ \\
2 & 0 & 44,10 & $-44,10$ \\
3 & 0 & 14,40 & $-14,40$ \\
4 & 0 & 87,75 & $-87,75$ \\
5 & 0 & 87,75 & $-87,75$ \\
6 & 0 & 87,75 & $-87,75$ \\
7 & $5.343,75$ & $1.762,75$ & $3.581,00$ \\
8 & 0 & 385,00 & $-385,00$ \\
9 & 0 & 100,35 & $-100,35$ \\
10 & 0 & 33,20 & $-33,20$ \\
11 & 0 & 87,75 & $-87,75$ \\
12 & 0 & 87,75 & $-87,75$ \\
13 & 0 & 87,75 & $-87,75$ \\
14 & 0 & $1.447,75$ & $1.952,25$ \\
15 & $3.400,00$ & 385,00 & $-385,00$ \\
16 & 0 & 100,35 & $-100,35$ \\
17 & 0 & 33,20 & $-33,20$ \\
18 & 0 & 87,75 & $-87,75$ \\
19 & 0 & 87,75 & $-87,75$ \\
20 & 0 & 87,75 & $-87,75$ \\
21 & $0,287,75$ & \\
& 0 & & $.712,25$ \\
\hline & 00 & 0 & 0 \\
\hline
\end{tabular}

Fonte: Apêndice 3 
Tabela A.6 - Fluxo de caixa do projeto de plantio de 1 ha de eucalipto em associação empresa-fazendeiro florestal, considerando a compra de $93,75 \%$ da madeira do $1^{\circ}$ corte e $100 \%$ da madeira do 2 - corte pela empresa financiadora no Estado de Minas Gerais e sem incluir o custo da terra - valores expressos em reais (R\$) de novembro de 1999 Projeto MG2.

\begin{tabular}{|c|c|c|c|}
\hline$\overline{\text { ANOS }}$ & BENEFICIOS & CUSTOS & FLUXO LIQUIDO \\
\hline 0 & 0 & 337,40 & $-337,40$ \\
\hline 1 & 0 & 146,85 & $-146,85$ \\
\hline 2 & 0 & 44,10 & $-44,10$ \\
\hline 3 & 0 & 14,40 & $-14,40$ \\
\hline 4 & 0 & 87,75 & $-87,75$ \\
\hline 5 & 0 & 87,75 & $-87,75$ \\
\hline 6 & 0 & 87,75 & $-87,75$ \\
\hline 7 & $5.343,75$ & $1.762,75$ & $3.581,00$ \\
\hline 8 & 0 & 385,00 & $-385,00$ \\
\hline 9 & 0 & 100,35 & $-100,35$ \\
\hline 10 & 0 & 33,20 & $-33,20$ \\
\hline 11 & 0 & 87,75 & $-87,75$ \\
\hline 12 & 0 & 87,75 & $-87,75$ \\
\hline 13 & 0 & 87,75 & $-87,75$ \\
\hline 14 & $4.845,00$ & $1.447,75$ & $3.397,25$ \\
\hline 15 & 0 & 385,00 & $-385,00$ \\
\hline 16 & 0 & 100,35 & $-100,35$ \\
\hline 17 & 0 & 33,20 & $-33,20$ \\
\hline 18 & 0 & 87,75 & $-87,75$ \\
\hline 19 & 0 & 87,75 & $-87,75$ \\
\hline 20 & 0 & 87,75 & $-87,75$ \\
\hline 21 & $3.000,00$ & $1.287,75$ & $1.712,25$ \\
\hline
\end{tabular}

Fonte: Apêndice 3 
Tabela A.7 - Fluxo de caixa do projeto de plantio de 1 ha de eucalipto em associação empresa-fazendeiro florestal, considerando a compra de $93,75 \%$ da madeira do $1^{\circ}$ corte pela empresa financiadora e a aquisição da terra para implantação do plantio, no Estado de Minas Gerais - valores expressos em reais (R\$) de novembro de 1999 - Projeto MG3.

\begin{tabular}{cccc}
\hline ANOS & BENEFICIOS & CUSTOS & FLUXO LIQUIDO \\
\hline 0 & 0 & 737,40 & $-737,40$ \\
1 & 0 & 146,85 & $-146,85$ \\
2 & 0 & 44,10 & $-44,10$ \\
3 & 0 & 14,40 & $-14,40$ \\
4 & 0 & 87,75 & $-87,75$ \\
5 & 0 & 87,75 & $-87,75$ \\
6 & 0 & 87,75 & $-87,75$ \\
7 & $5.343,75$ & $1.762,75$ & $3.581,00$ \\
8 & 0 & 385,00 & $-385,00$ \\
9 & 0 & 100,35 & $-100,35$ \\
10 & 0 & 33,20 & $-33,20$ \\
11 & 0 & 87,75 & $-87,75$ \\
12 & 0 & 87,75 & $-87,75$ \\
13 & 0 & 87,75 & $-87,75$ \\
14 & 0 & $1.447,75$ & $1.952,25$ \\
15 & $3.400,00$ & 385,00 & $-385,00$ \\
16 & 0 & 100,35 & $-100,35$ \\
17 & 0 & 33,20 & $-33,20$ \\
18 & 0 & 87,75 & $-87,75$ \\
19 & 0 & 87,75 & $-87,75$ \\
20 & 0 & $1.287,75$ & $-87,75$ \\
21 & $0.400,00$ & & $2.112,25$ \\
\hline
\end{tabular}

Fonte: Apêndice 3 
Tabela A.8 - Fluxo de caixa do projeto de plantio de 1 ha de eucalipto em associação empresa-fazendeiro florestal, considerando a compra de $93,75 \%$ da madeira do $1^{\circ}$ corte e $100 \%$ da madeira do $2^{\circ}$ corte pela empresa financiadora e a aquisição da terra para implantação do plantio, no Estado de Minas Gerais- valores expressos em reais (R\$) de novembro de 1999 - Projeto MG4.

\begin{tabular}{|c|c|c|c|}
\hline ANOS & BENEFICIOS & CUSTOS & FLUXO LIQUUIDO \\
\hline 0 & 0 & 737,40 & $-737,40$ \\
\hline 1 & 0 & 146,85 & $-146,85$ \\
\hline 2 & 0 & 44,10 & $-44,10$ \\
\hline 3 & 0 & 14,40 & $-14,40$ \\
\hline 4 & 0 & 87,75 & $-87,75$ \\
\hline 5 & 0 & 87,75 & $-87,75$ \\
\hline 6 & 0 & 87,75 & $-87,75$ \\
\hline 7 & $5.343,75$ & $1.762,75$ & $3.581,00$ \\
\hline 8 & 0 & 385,00 & $-385,00$ \\
\hline 9 & 0 & 100,35 & $-100,35$ \\
\hline 10 & 0 & 33,20 & $-33,20$ \\
\hline 11 & 0 & 87,75 & $-87,75$ \\
\hline 12 & 0 & 87,75 & $-87,75$ \\
\hline 13 & 0 & 87,75 & $-87,75$ \\
\hline 14 & $4.845,00$ & $1.447,75$ & $3.397,25$ \\
\hline 15 & 0 & 385,00 & $-385,00$ \\
\hline 16 & 0 & 100,35 & $-100,35$ \\
\hline 17 & 0 & 33,20 & $-33,20$ \\
\hline 18 & 0 & 87,75 & $-87,75$ \\
\hline 19 & 0 & 87,75 & $-87,75$ \\
\hline 20 & 0 & 87,75 & $-87,75$ \\
\hline 21 & $3.400,00$ & $1.287,75$ & $2.112,25$ \\
\hline
\end{tabular}

Fonte: Apêndice 3 
Tabela A.9 - Fluxo de caixa do projeto de plantio de 1 ha de eucalipto sem incluir o custo da terra e com doação de mudas ao produtor rural no Estado do Paraná - valores expressos em reais $(\mathrm{R} \$)$ em novembro de 1999 - Projeto PR1.

\begin{tabular}{|c|c|c|c|}
\hline ANOS & BENEFICIOS & CUSTOS & FLUXO LIQUIDO \\
\hline 0 & 0 & 307,08 & $-307,08$ \\
\hline 1 & 0 & 82,15 & $-82,15$ \\
\hline 2 & 0 & 18,08 & $-18,08$ \\
\hline 3 & 0 & 18,08 & $-18,08$ \\
\hline 4 & 0 & 18,08 & $-18,08$ \\
\hline 5 & 0 & 18,08 & $-18,08$ \\
\hline 6 & 0 & 18,08 & $-18,08$ \\
\hline 7 & $1.687,50$ & 215,76 & $1.471,74$ \\
\hline 8 & 0 & 98,64 & $-98,64$ \\
\hline 9 & 0 & 18,08 & $-18,08$ \\
\hline 10 & 0 & 18,08 & $-18,08$ \\
\hline 11 & 0 & 18,08 & $-18,08$ \\
\hline 12 & 0 & 18,08 & $-18,08$ \\
\hline 13 & 0 & 18,08 & $-18,08$ \\
\hline 14 & $1.612,50$ & 215,76 & $1.396,74$ \\
\hline 15 & 0 & 98,64 & $-98,64$ \\
\hline 16 & 0 & 18,08 & $-18,08$ \\
\hline 17 & 0 & 18,08 & $-18,08$ \\
\hline 18 & 0 & 18,08 & $-18,08$ \\
\hline 19 & 0 & 18,08 & $-18,08$ \\
\hline 20 & 0 & 18,08 & $-18,08$ \\
\hline 21 & $1.440,00$ & 162,72 & $1.277,28$ \\
\hline
\end{tabular}

Fonte: Apêndice 4 
Tabela A.10 - Fluxo de caixa do projeto de plantio de 1 ha de eucalipto sem incluir o custo da terra e com aquisição de mudas pelo produtor rural no Estado do Paraná valores expressos em reais (R\$) em novembro de 1999 - Projeto PR2.

\begin{tabular}{|c|c|c|c|}
\hline$\overline{A N O S}$ & BENEFICIOS & CUSTOS & FLUXO LIQUUIDO \\
\hline 0 & 0 & 435,39 & $-435,39$ \\
\hline 1 & 0 & 82,15 & $-82,15$ \\
\hline 2 & 0 & 18,08 & $-18,08$ \\
\hline 3 & 0 & 18,08 & $-18,08$ \\
\hline 4 & 0 & 18,08 & $-18,08$ \\
\hline 5 & 0 & 18,08 & $-18,08$ \\
\hline 6 & 0 & 18,08 & $-18,08$ \\
\hline 7 & $1.687,50$ & 215,76 & $1.471,74$ \\
\hline 8 & 0 & 98,64 & $-98,64$ \\
\hline 9 & 0 & 18,08 & $-18,08$ \\
\hline 10 & 0 & 18,08 & $-18,08$ \\
\hline 11 & 0 & 18,08 & $-18,08$ \\
\hline 12 & 0 & 18,08 & $-18,08$ \\
\hline 13 & 0 & 18,08 & $-18,08$ \\
\hline 14 & $1.612,50$ & 215,76 & $1.396,74$ \\
\hline 15 & 0 & 98,64 & $-98,64$ \\
\hline 16 & 0 & 18,08 & $-18,08$ \\
\hline 17 & 0 & 18,08 & $-18,08$ \\
\hline 18 & 0 & 18,08 & $-18,08$ \\
\hline 19 & 0 & 18,08 & $-18,08$ \\
\hline 20 & 0 & 18,08 & $-18,08$ \\
\hline 21 & $1.440,00$ & 162,72 & $1.277,28$ \\
\hline
\end{tabular}

Fonte: Apêndice 4 
Tabela A.11 - Fluxo de caixa do projeto de plantio de 1 ha de eucalipto considerando o custo da terra para implantação do plantio e com a doação de mudas ao produtor rural no Estado do Paraná - valores expressos em Reais (R\$) em novembro de 1999 - Projeto PR3.

\begin{tabular}{|c|c|c|c|}
\hline$\overline{\mathrm{ANOS}}$ & BENEFICIOS & CUSTOS & FLUXO LIQUIDO \\
\hline 0 & 0 & $1.614,61$ & $-1.614,61$ \\
\hline 1 & 0 & 82,15 & $-82,15$ \\
\hline 2 & 0 & 18,08 & $-18,08$ \\
\hline 3 & 0 & 18,08 & $-18,08$ \\
\hline 4 & 0 & 18,08 & $-18,08$ \\
\hline 5 & 0 & 18,08 & $-18,08$ \\
\hline 6 & 0 & 18,08 & $-18,08$ \\
\hline 7 & $1.687,50$ & 215,76 & $1.471,74$ \\
\hline 8 & 0 & 98,64 & $-98,64$ \\
\hline 9 & 0 & 18,08 & $-18,08$ \\
\hline 10 & 0 & 18,08 & $-18,08$ \\
\hline 11 & 0 & 18,08 & $-18,08$ \\
\hline 12 & 0 & 18,08 & $-18,08$ \\
\hline 13 & 0 & 18,08 & $-18,08$ \\
\hline 14 & $1.612,50$ & 215,76 & $1.396,74$ \\
\hline 15 & 0 & 98,64 & $-98,64$ \\
\hline 16 & 0 & 18,08 & $-18,08$ \\
\hline 17 & 0 & 18,08 & $-18,08$ \\
\hline 18 & 0 & 18,08 & $-18,08$ \\
\hline 19 & 0 & 18,08 & $-18,08$ \\
\hline 20 & 0 & 18,08 & $-18,08$ \\
\hline 21 & $2.747,53$ & 162,72 & $2.584,81$ \\
\hline
\end{tabular}

Fonte: Apêndice 4 
Tabela A.12 - Fluxo de caixa do projeto de plantio de 1 ha de eucalipto considerando o custo da terra para a implantação do plantio e com a aquisição de mudas pelo produtor rural no Estado do Paraná - valores expressos em Reais (R\$) em novembro de 1999 Projeto PR4.

\begin{tabular}{|c|c|c|c|}
\hline ANOS & BENEFICIOS & CUSTOS & FLUXO LIQQUIDO \\
\hline 0 & $\overline{0}$ & $1.742,92$ & $-1.742,92$ \\
\hline 1 & 0 & 82,15 & $-82,15$ \\
\hline 2 & 0 & 18,08 & $-18,08$ \\
\hline 3 & 0 & 18,08 & $-18,08$ \\
\hline 4 & $\cdot 0$ & 18,08 & $-18,08$ \\
\hline 5 & 0 & 18,08 & $-18,08$ \\
\hline 6 & 0 & 18,08 & $-18,08$ \\
\hline 7 & $1.687,50$ & 215,76 & $1.471,74$ \\
\hline 8 & 0 & 98,64 & $-98,64$ \\
\hline 9 & 0 & 18,08 & $-18,08$ \\
\hline 10 & 0 & 18,08 & $-18,08$ \\
\hline 11 & 0 & 18,08 & $-18,08$ \\
\hline 12 & 0 & 18,08 & $-18,08$ \\
\hline 13 & 0 & 18,08 & $-18,08$ \\
\hline 14 & $1.612,50$ & 215,76 & $1.396,74$ \\
\hline 15 & 0 & 98,64 & $-98,64$ \\
\hline 16 & 0 & 18,08 & $-18,08$ \\
\hline 17 & $\cdot 0$ & 18,08 & $-18,08$ \\
\hline 18 & 0 & 18,08 & $-18,08$ \\
\hline 19 & 0 & 18,08 & $-18,08$ \\
\hline 20 & 0 & 18,08 & $-18,08$ \\
\hline 21 & $2.747,53$ & 162,72 & $2.584,81$ \\
\hline
\end{tabular}

Fonte: Apêndice 4 
Apêndice 2 - Informações gerais sobre as receitas e custos de um projeto de reflorestamento com eucalipto em pequena escala no Estado de São Paulo 


\section{Plantio do eucalipto sem considerar o custo da terra}

1. Projeto SP1 - plantio do eucalipto sem considerar o custo da terra e com doação de mudas.

A densidade de plantio considerada é de 1666 plantas/ha, sob espaçamento $3 \times 2$ metros. As operações executadas e os coeficientes técnicos considerados são resultados de pesquisa de campo junto à associação de recuperação florestal da Bacia do Rio Piracicaba (Florespi). Os preços da lenha de eucalipto cortada e empilhada na fazenda foram levantados junto às serrarias do Estado, em novembro de 1999, e foi cotado, em média, a R\$ 7,50/st.

\subsection{Benefícios}

\subsubsection{Receita da venda dos produtos da exploração florestal}

Tabela B.1 - Receita da venda da lenha de eucalipto proveniente da exploração de 1 hectare de eucalipto, com doação de mudas no estado de São Paulo.

\begin{tabular}{c|c|c|c}
\hline Idade (anos) & Volume Retirado (st/ha) & Preço Unitário (R\$/st) & Receita Total (R\$) \\
\hline 7 & 350,00 & 7,50 & $2.625,00$ \\
14 & 310,00 & 7,50 & $2.325,00$ \\
21 & 280,00 & 7,50 & $2.100,00$ \\
\hline
\end{tabular}

Fonte: dados de pesquisa

\subsection{Custos}

1.2.1 Investimento Inicial (ano 0): não estão sendo considerados custos com a aquisição/venda de terra no início e final do projeto, respectivamente.

\subsubsection{Custo de Implantação}

Tabela B.2 - Custos de implantação (ano 0) de 1 hectare de eucalipto com doação de mudas no estado de São Paulo.

\begin{tabular}{|c|c|c|c|c|}
\hline Item & Unidade/ha & Quantidade & Preço Unitário (R\$) & Valor Total (R\$) \\
\hline 1. Mecanização & & & & \\
\hline Aração & Hora-trator & 1 & 29,02 & 29,02 \\
\hline Gradeação & Hora-trator & 2 & 11,79 & 23,58 \\
\hline Sulcamento/Adubação & Hora-trator & 1 & 14,21 & 14,21 \\
\hline $\begin{array}{l}\text { Roçada Mecanizada nas } \\
\text { entrelinhas }\end{array}$ & Hora-trator & 1 & 32,43 & 32,43 \\
\hline 2. Mão-de-obra & & & & \\
\hline Combate a formigas & Homem-dia & 1 & 10,07 & 10,07 \\
\hline Plantio & Homem-dia & 3 & 10,07 & 30,21 \\
\hline Replantio & Homem-dia & 1 & 10,07 & 10,07 \\
\hline Capina Manual nas linhas & Homem-dia & 3 & 10,07 & 30,21 \\
\hline Adubação & Homem-dia & 2 & 10,07 & 20,14 \\
\hline 3. Insumos & & & & \\
\hline Formicidas & $\mathrm{kg}$ & 1,25 & 8,58 & 10,73 \\
\hline NPK & $\mathrm{kg}$ & 250 & 0,31 & 77,50 \\
\hline Total & & & & 288,17 \\
\hline
\end{tabular}

Fonte: IEA (1999) e dados de pesquisa 


\subsection{2 - Custos anuais de manutenção}

Tabela B.3 - Custo de Manutenção do $1^{\circ}$ ano de 1 hectare plantado com eucalipto, com doação de mudas no estado de São Paulo.

\begin{tabular}{l|c|c|c|c}
\hline \multicolumn{1}{c|}{ Item } & Unidade/ha & Quantidade & Preço Unitário (R\$) & Valor total (R\$) \\
\hline 1. Mão-de-obra & Homem-dia & 2 & 10,07 & 20,14 \\
Capina manual nas linhas & Homem-dia & 0,5 & 10,07 & 5,04 \\
$\begin{array}{l}\text { Combate a formigas } \\
\text { 2- Mecanização }\end{array}$ & $\cdot$ & 1 & 32,43 & 32,43 \\
$\begin{array}{l}\text { Roçada mec. Entrelinhas } \\
\text { 3- Insumos }\end{array}$ & Hora-trator & & 8,58 & 5,15 \\
Formicida & $\mathrm{Kg}$ & 0,6 & & $\mathbf{6 2 , 7 6}$ \\
\hline Total & & & & \\
\hline
\end{tabular}

Fonte: IEA (1999) e dados de pesquisa

Tabela B.4 - Custo de manutenção do $2^{\circ}$ ano de 1 hectare plantado com eucalipto, com doação de mudas no estado de São Paulo.

\begin{tabular}{l|c|c|c|c}
\hline \multicolumn{1}{c|}{ Item } & Unidade/ha & Quantidade & Preço Unitário (R\$) & Valor total (R\$) \\
\hline 1 Mão-de-obra & & & & 10,07 \\
$\begin{array}{l}\text { Capina manual nas linhas } \\
\text { Combate a formigas }\end{array}$ & Homem-dia & 1 & 10,07 & 10,07 \\
2- Mecanização & Homem-dia & 0,5 & 32,43 & 5,04 \\
$\begin{array}{l}\text { Roçada mec. Entrelinhas } \\
\text { 3-Insumos }\end{array}$ & Hora-trator & 1 & & 32,43 \\
Formicida & $\mathrm{kg}$ & 0,6 & 8,58 & 5,15 \\
\hline Total & & & & $\mathbf{5 2 , 6 9}$ \\
\hline
\end{tabular}

Fonte: IEA (1999) e dados de pesquisa

Tabela B.5 - Custo de Manutenção do 3ำ, $4^{\circ}, 5^{\circ}$ e $6^{\circ}$ ano de 1 hectare plantado com eucalipto, com doação de mudas no estado de São Paulo.

\begin{tabular}{l|c|c|c|c}
\hline \multicolumn{1}{c|}{ Item } & Unidade/ha & Quantidade & Preço Unitário (R\$) & Valor total (R\$) \\
\hline $\begin{array}{l}\text { 1. Mão-de-obra } \\
\begin{array}{l}\text { Combate a formigas } \\
\text { 2. Mecanização } \\
\text { Roçada mecanizada }\end{array}\end{array}$ & Homèm-dia & 0,5 & 10,07 & 5,04 \\
3 Insumos & Homem-dia & 1 & 32,43 & 32,43 \\
Formicida & $\mathrm{kg}$ & 0,6 & 8,58 & 5,15 \\
\hline Total & & & & $\mathbf{4 2 , 6 2}$ \\
\hline
\end{tabular}

Fonte: IEA (1999) e dados de pesquisa

Tabela B.6 - Custo de Manutenção do $8^{\circ}, 9^{\circ}, 10^{\circ}, 11^{\circ}, 12^{\circ}$ e $13^{\circ}$ ano de 1 hectare plantado com eucalipto, com doação de mudas no estado de São Paulo.

\begin{tabular}{l|c|c|c|c}
\hline \multicolumn{1}{c|}{ Item } & Unidade/ha & Quantidade & Preço Unitário (R\$) & Valor total (R\$) \\
\hline $\begin{array}{l}\text { M Mão-de-obra } \\
\begin{array}{l}\text { Combate a formigas } \\
\text { 2 Mecanização } \\
\text { Roçada mecanizada }\end{array}\end{array}$ & Homem-dia & $\mathbf{0 , 5}$ & 10,07 & 5,04 \\
$\begin{array}{l}\mathbf{3} \text { Insumos } \\
\text { Formicida }\end{array}$ & Homem-dia & 1 & 32,43 & 32,43 \\
\hline Total & $\mathrm{kg}$ & 0,6 & 8,58 & 5,15 \\
\hline
\end{tabular}

Fonte: IEA (1999) e dados de pesquisa 
Tabela B.7 - Custo de Manutenção do $15^{\circ}, 16^{\circ}, 17^{\circ}, 18^{\circ}, 19^{\circ}$ e $20^{\circ}$ ano de 1 hectare plantado com eucalipto, com doação de mudas no estado de São Paulo.

\begin{tabular}{l|c|c|c|c}
\hline \multicolumn{1}{c|}{ Item } & Unidade/ha & Quantidade & Preço Unitário (R\$) & Valor total (R\$) \\
\hline $\begin{array}{l}\text { I Mão-de-obra } \\
\begin{array}{l}\text { Combate a formigas } \\
\text { Mecanização }\end{array}\end{array}$ & Homem-dia & 0,5 & 10,07 & 5,04 \\
$\begin{array}{l}\text { Roçada mecanizada } \\
\text { 3 Insumos }\end{array}$ & Homem-dia & 1 & 32,43 & 32,43 \\
Formicida & $\mathrm{kg}$ & $\mathbf{0 , 6}$ & 8,58 & 5,15 \\
\hline Total & & & & $\mathbf{4 2 , 6 2}$ \\
\hline
\end{tabular}

Fonte: IEA (1999) e dados de pesquisa

Tabela B.8 - Custo de exploração e mariutenção do $7^{\circ}$, $14^{\circ}$ e $21^{\circ}$ ano de 1 hectare plantado com eucalipto, com doação de mudas no estado de São Paulo.

\begin{tabular}{l|c|c|c|c}
\hline \multicolumn{1}{c|}{ Item } & Unidade/ha & Quantidade & Preço Unitário (R\$) & Valor total (R\$) \\
\hline 1. Mão-de-obra & Homem-dia & 1,0 & 10,07 & 10,07 \\
Combate a formiga & Homem-dia & 10 & 10,07 & 100,70 \\
Corte raso & Homem-dia & 5 & 10,07 & 50,35 \\
$\begin{array}{l}\text { Empilhamento } \\
\text { 2 Insumos }\end{array}$ & $\mathrm{Kg}$ & 1,25 & 8,58 & 10,73 \\
$\begin{array}{l}\text { Formicida } \\
\mathbf{3} \text { Mecanização } \\
\text { Roçada mecanizada }\end{array}$ & Hora-trator & $\mathbf{1 , 0}$ & $\mathbf{3 2 , 4 3}$ & 32,43 \\
\hline Total & & & & $\mathbf{2 0 4 , 2 8}$ \\
\hline
\end{tabular}

Fonte: IEA (1999) e dados de pesquisa

2. Projeto SP2 - plantio do eucalipto sem considerar o custo da terra e com aquisição de mudas.

\subsection{Benefícios}

2.1.1 Receita da venda dos produtos da exploração florestal : Idem tabela B.1.

\subsection{Custos}

2.2.1 Investimento Inicial (ano 0): não estão sendo considerados custos com a aquisição/venda de terra no início e final do projeto, respectivamente.

\subsubsection{Custo de Implantação}


Tabela B.9 - Custos de implantação de 1 hectare de eucalipto com aquisição das mudas no estado de São Paulo.

\begin{tabular}{|c|c|c|c|c|}
\hline Item & Unidade/ha & Quantidade & Preço Unitário (RS) & Valor Total (RS) \\
\hline \multicolumn{5}{|l|}{$1 \quad$ Mecanização } \\
\hline Aração & Hora-trator & 1 & 29,02 & 29,02 \\
\hline Gradeação & Hora-trator & 2 & 11,79 & 23,58 \\
\hline Sulcamento/Adubação & Hora-trator & 1 & 14,21 & 14,21 \\
\hline Roçada Mecanizada nas entrelinhas & Hora-trator & 1 & 32,43 & 32,43 \\
\hline 2 Mão-de-obra & & & & \\
\hline Combate à formigas & Homem-dia & 1 & 10,07 & 10,07 \\
\hline Plantio & Homem-dia & 3 & 10,07 & 30,21 \\
\hline Replantio & Homem-dia & 1 & 10,07 & 10,07 \\
\hline Capina Manual nas linhas & Homem-dia & 3 & 10,07 & 30,21 \\
\hline Adubação & Homem-dia & 2 & 10,07 & 20,14 \\
\hline 3 Insumos & & & & \\
\hline Formicidas & $\mathrm{Kg}$ & 1,25 & 8,58 & 10,73 \\
\hline NPK & $\mathrm{Kg}$ & 250 & 0,31 & 77,50 \\
\hline Mudas & Unidade & 1.833 & 0,08 & 146,64 \\
\hline Total & & & & 434,81 \\
\hline
\end{tabular}

Fonte: IEA (1999), dados de pesquisa

2.2.2 - Custos anuais de manutenção: Idem tabelas B.3 a B.8.

Plantio de 1 hectare de eucalipto considerando custo de aquisição da terra

3. Projeto SP3 - Plantio do eucalipto considerando o custo de aquisição da terra e a doação de mudas ao produtor rural.

\subsection{Benefícios}

\subsubsection{Receita da venda da terra :}

O preço médio da terra para reflorestamento praticado no Estado de São Paulo, segundo o Instituto de Economia Agrícola do Estado de São Paulo, em novembro de 1999, foi cotado a R\$ 1.634,78.

3.1.2 Receita da venda dos produtos da exploração florestal: Idem tabela B.1, acrescentando no $21^{\circ}$ ano o valor de $\mathrm{R} \$ 1.634,78$.

\subsection{Custos}

\subsubsection{Investimento Inicial (ano 1)}

3.2.1.1 Compra da terra: Idem 3.1.1.

3.2.1.2 Custo de Implantação: Idem tabela B.2.

3.2.2 Custos anuais de manutenção: Idem tabelas B.3 a B.8. 
4. Projeto SP4 - plantio do eucalipto considerando o custo de aquisição da terra e a aquisição de mudas pelo produtor rural.

\subsection{Benefícios}

4.1.1 Receita da venda da terra no final do projeto: Idem 3.1.1.

4.1.2 Receita da venda dos produtos da exploração florestal: Idem tabela B.1, acrescentando no $21^{\circ}$ ano o valor de $\mathrm{R} \$ 1.634,78$.

\subsection{Custos}

\subsubsection{Investimento Inicial (ano 1)}

4.2.1.1 Compra da terra: Idem 3.1.1.

4.2.1.2 Custo de Implantação: Idem tabela B.9.

4.2.2 Custos anuais de manutenção: Idem tabelas B.3 a B.8. 
Apêndice 3 - Informações gerais sobre as receitas e custos de um projeto de reflorestamento com eucalipto em pequena escala no Estado de Minas Gerais 


\section{Plantio de 1 hectare de eucalipto sem considerar o custo da terra}

1. Projeto MG1 - plantio de eucalipto considerando a compra da madeira de eucalipto pela empresafinanciadora no $1^{\circ}$ corte.

A densidade de plantio considerada é de 1333 plantas/ha, sob espaçamento 3,0 x 2,5 m. As operações, os coeficientes técnicos sobre o uso dos insumos e mão-de-obra e a produtividade considerados foram coletados junto a empresa participante do "Programa Fazendeiro Florestal" na região do Vale do Rio Doce - MG. O preço do estéreo da lenha de eucalipto referente a novembro de 1999 foi coletado junto ao Instituto Estadual de Florestas de Minas Gerais (R\$ 10,00). Não é utilizada mecanização nas operações consideradas.

\subsection{Benefícios}

\subsubsection{Receita da venda dos produtos da exploração florestal}

Considera-se que no $1^{\circ}$ corte a empresa fomentadora (empresa de celulose) paga pelo estéreo de madeira mais do que se consegue no $2^{\circ}$ e $3^{\circ}$ corte, onde se vende o produto como lenha.

Tabela C.1 - Receita da venda da madeira de eucalipto proveniente da exploração de 1 hectare, considerando a compra da madeira de eucalipto pela empresa financiadora no $1^{0}$ corte.

\begin{tabular}{c|c|c|c}
\hline Idade (anos) & Volume Retirado (st/ha) & Preço Unitário (R\$/st) & Receita Total (R\$) \\
\hline 7 & $375^{*}$ & 14,25 & $5.343,75$ \\
14 & 340 & 10,00 & $3.400,00$ \\
21 & 300 & 10,00 & $3.000,00$ \\
\hline
\end{tabular}

Fonte: Abracave (2000) e dados de pesquisa

* Apesar de ser retirado 400 st/ha, 25 st/ha são entregues como pagamento aos insumos e mudas oferecidas pela empresa financiadora na implantação da cultura.

\subsection{Custos}

1.2.1 Investimento Inicial (ano 0): não estão sendo considerados custos com a aquisição/venda de terra no início e final do projeto, respectivamente. Também as mudas e insumos são concedidos pela empresa fomentadora.

\subsubsection{Custo de Implantação}


Tabela C.2 - Custos de implantação (ano 0) de 1 hectare de eucalipto com doação das mudas e insumos pela empresa financiadora.

\begin{tabular}{|c|c|c|c|c|}
\hline Item & Unidade/ha & Quantidade & Preço Unitário (R\$) & Valor Total (RS) \\
\hline 1 Mão-de-obra & & & & \\
\hline Const. manual aceiro & Homem-hora & 5,7 & 1,5 & 8,55 \\
\hline Roçada manual & Homem-hora & 12,5 & 1,5 & 18,75 \\
\hline Queima & Homem-hora & 1,5 & 1,5 & 2,25 \\
\hline Capina química & Homem-hora & 14 & 1,5 & 21,00 \\
\hline $1^{\circ}$ Combate a formiga & Homem-hora & 7,8 & 1,5 & 11,70 \\
\hline Encoivara/queima & Homem-hora & 3 & 1,5 & 4,50 \\
\hline Alinhar/marcar & Homem-hora & 9 & 1,5 & 13,50 \\
\hline Covear & Homem-hora & 22 & 1,5 & 33,00 \\
\hline $2^{\circ}$ Combate a formiga & Homem-hora & 7,8 & 1,5 & 11,70 \\
\hline Adubar & Homem-hora & 12 & 1,5 & 18,00 \\
\hline Recebimento/manter mudas & Homem-hora & 2,5 & 1,5 & 3,75 \\
\hline Plantar & Homem-hora & 22 & 1,5 & 33,00 \\
\hline $3^{\circ}$ Combate a formiga & Homein-hora & 7,8 & 1,5 & 11,70 \\
\hline Replantio & Homem-hora & 15 & 1,5 & 22,50 \\
\hline Const. cerca & $\mathrm{km}$ & 0,03 & 1450 & 43,50 \\
\hline Abertura de estradas & Homem-equip & 2 & 40 & 80,00 \\
\hline Total & & & & 337,40 \\
\hline
\end{tabular}

Fonte: dados de pesquisa

\subsection{2 - Custos anuais de manutenção}

Tabela C.3 - Custo de Manutenção do $1^{\circ}$ ano de 1 hectare plantado com eucalipto, com doação dos insumos pela empresa financiadora.

\begin{tabular}{l|c|c|c|c}
\hline \multicolumn{1}{c|}{ Item } & Unidade/ha & Quantidade & Preço Unitário (R\$) & Valor total (R\$) \\
\hline 1 Mão-de-Obra & & & & \\
Conserv manual aceiro & Homem-hora & 3,9 & 1,5 & 5,85 \\
Combate a formiga & Homem-hora & 4,5 & 1,5 & 6,75 \\
Comb.sistemático a formiga & Homem-hora & 2 & 1,5 & 3,00 \\
Capina manual & Homem-hora & 7,5 & 1,5 & 11,25 \\
Capina química & Homem-hora & 22,5 & 1,5 & 33,75 \\
Adubar cobertura & Homem-hora & 10 & 1,5 & 15,00 \\
Adubar cobertura & Homem-hora & 10 & 1,5 & 15,00 \\
Coroamento & Homem-hora & 37,50 & 1,5 & 56,25 \\
\hline Total & & & & $\mathbf{1 4 6 , 8 5}$ \\
\hline
\end{tabular}

Fonte: dados de pesquisa

Tabela C. 4 - Custo de Manutenção do $2^{\circ}$ ano de 1 hectare plantado com eucalipto, com doação dos insumos pela empresa financiadora.

\begin{tabular}{l|c|c|c|c}
\hline \multicolumn{1}{c|}{ Item } & Unidade/ha & Quantidade & Preço Unitário (R\$) & Valor total (R\$) \\
\hline 1 Mão-de-Obra & & & & \\
Conserv. manual aceiro & Homem-hora & 3,9 & 1,5 & 5,85 \\
Roçada manual & Homem-hora & 6,0 & 1,5 & 9,00 \\
Combate a formiga & Homem-hora & 4,5 & 1,5 & 6,75 \\
Capina química & Homem-hora & 15 & 1,5 & 22,50 \\
\hline Total & & & & 44,10 \\
\hline
\end{tabular}

Fonte: dados de pesquisa 
Tabela C.5 - Custo de Manutenção do $3^{\circ}$ ano de 1 hectare plantado com eucalipto, com doação dos insumos pela empresa financiadora.

\begin{tabular}{l|c|c|c|c}
\hline \multicolumn{1}{c|}{ Item } & Unidade/ha & Quantidade & Preço Unitário (R\$) & Valor total (R\$) \\
\hline $\mathbf{1 \quad \text { Mão-de-Obra }}$ & & & & \\
Conserv. manual aceiro & Homem-hora & 3,9 & 1,5 & 5,85 \\
Combate a formiga & Homem-hora & 1,2 & 1,5 & $\mathbf{1 , 8 0}$ \\
Capina química & Homem-hora & 4,5 & 1,5 & $\mathbf{6 , 7 5}$ \\
\hline Total & & & & $\mathbf{1 4 , 4 0}$ \\
\hline
\end{tabular}

Fonte: dados de pesquisa

Tabela C. 6 - Custo de Manutenção do $4^{\circ}$ ao $7^{\circ}, 11^{\circ}$ ao $14^{\circ}$ e $18^{\circ}$ ao $21^{\circ}$ anos de 1 hectare plantado com eucalipto, com doação dos insumos pela empresa financiadora.

\begin{tabular}{l|c|c|c|c}
\hline \multicolumn{1}{c|}{ Item } & Unidade/ha & Quantidade & Preço Unitário (R\$) & Valor total (R\$) \\
\hline $\mathbf{1}$ Mão-de-Obra & & & & \\
Conserv. manual aceiro & Homem-hora & 58,50 & 1,5 & 87,75 \\
\hline Total & & & & $\mathbf{8 7 , 7 5}$ \\
\hline
\end{tabular}

Fonte: dados de pesquisa

Tabela C.7 - Custo de Manutenção do $8^{\circ}$ e $15^{\circ}$ anos, de 1 hectare plantado com eucalipto, com aquisição dos insumos pelo produtor rural

\begin{tabular}{l|c|c|c|c}
\hline \multicolumn{1}{c|}{ Item } & Unidade/ha & Quantidade & Preço Unitário (R\$) & Valor total (R\$) \\
\hline 1 Mão-de-Obra & & & & \\
Conserv. manual aceiro & Homem-hora & 3,9 & 1,5 & 5,85 \\
Combate a formiga & Homem-hora & 4,5 & 1,5 & 6,75 \\
Comb. sistemático a formiga & Homem-hora & 2 & 1,5 & 3,00 \\
Capina manual & Homem-hora & 7,5 & 1,5 & 11,25 \\
Capina química & Homem-hora & 22,5 & 1,5 & 33,75 \\
Adubar cobertura & Homem-hora & 10 & 1,5 & 15,00 \\
Adubar cobertura & Homem-hora & 10 & 1,5 & $\mathbf{1 5 , 0 0}$ \\
Coroamento & Homem-hora & 37,50 & 1,5 & 56,25 \\
2 Insumos & & & & 31,85 \\
Formicida & $\mathrm{Kg}$ & 9,1 & 3,5 & 34,00 \\
Herbicida & $\mathrm{Litro}$ & 2,0 & 17,0 & 77,50 \\
Fosfato & $\mathrm{Kg}$ & 250 & 0,31 & $\mathbf{9 4 , 8 0}$ \\
KCL + B & $\mathrm{Kg}$ & 200 & 0,474 & $\mathbf{3 8 5 , 0 0}$ \\
\hline Total & & & & \\
\hline
\end{tabular}

Fonte: dados de pesquisa

Tabela C. 8 - Custo de Manutenção do $9^{\circ}$ e $16^{\circ}$ ano, de 1 hectare plantado com eucalipto, com aquisição dos insumos pelo produtor rural.

\begin{tabular}{|c|c|c|c|c|}
\hline Item & Unidade/ha & Quantidade & Preço Unitário (R\$) & Valor total (R\$) \\
\hline 1 Mão-de-Obra & & & & \\
\hline Conserv. manual aceiro & Homem-hora & 3,9 & 1,5 & 5,85 \\
\hline Roçada manual & Homem-hora & 6,0 & 1,5 & 9,00 \\
\hline Combate a formiga & Homem-hora & 4,5 & 1,5 & 6,75 \\
\hline Capina química & Homem-hora & 15 & 1,5 & 22,50 \\
\hline 2 Insumos & & & & \\
\hline Herbicida & Litro & 3 & 17 & 51,00 \\
\hline Formicida & $\mathrm{Kg}$ & 1,5 & 3,5 & 5,25 \\
\hline Total & & & & 100,35 \\
\hline
\end{tabular}

Fonte: dados de pesquisa 
Tabela C.9 - Custo de manutenção do $10^{\circ}$ e $17^{\circ}$ anos, de 1 hectare plantado com eucalipto, com aquisição dos insumos pelo produtor rural.

\begin{tabular}{l|c|c|c|c}
\hline \multicolumn{1}{c|}{ Item } & Unidade/ha & Quantidade & Preço Unitário (R\$) & Valor total (R\$) \\
\hline 1 Mão-de-Obra & & & & \\
Conserv. manual aceiro & Homem-hora & 3,9 & 1,5 & 5,85 \\
Combate a formiga & Homem-hora & 1,2 & 1,5 & 1,80 \\
Capina química & Homem-hora & 4,5 & 1,5 & 6,75 \\
$\mathbf{2} \quad$ Insumos & $\mathrm{Kg}$ & 1,0 & 3,5 & 3,5 \\
Formicida & Litro & 0,9 & 17,0 & 15,30 \\
Herbicida & & & & $\mathbf{3 3 , 2 0}$ \\
\hline Total & & & \\
\hline
\end{tabular}

Fonte: dados de pesquisa

Tabela C.10 - Custo de exploração.

\begin{tabular}{c|c|c|c|c}
\hline Ano & $\begin{array}{c}\text { Total produzido } \\
\text { (estéreo) }\end{array}$ & $\begin{array}{c}\text { Custo unitário } \\
\text { (R\$/estéreo) }\end{array}$ & Custo total (R\$) & Total (R\$) \\
\hline $7^{\circ}$ & 375 & 4,00 & $1.500,00$ & $1.675,00$ \\
\hline $14^{\circ}$ & 25 & 7,00 & 175,00 & $1.360,00$ \\
\hline $21^{\circ}$ & 340 & 4,00 & $1.360,00$ & $1.200,00$ \\
\hline
\end{tabular}

Fonte: dados de pesquisa

2. Projeto MG2 - Plantio de eucalipto considerando a compra da madeira de eucalipto pela empresa financiadora no $1^{\circ}$ e $2^{\circ}$ cortes e venda como lenha do $3^{\circ}$ corte.

\subsection{Benefícios}

\subsubsection{Receita da venda dos produtos da exploração florestal}

Tabela C.11 - Receita da venda da madeira de eucalipto proveniente da exploração de 1 ha, considerando a compra da madeira de eucalipto pela empresa financiadora no $1^{\circ}$ e 2 cortes.

\begin{tabular}{c|c|c|c}
\hline Idade (anos) & Volume Retirado (st/ha) & Preço Unitário (R\$/st) & Receita Total (R\$) \\
\hline 7 & 375 & 14,25 & $5.343,75$ \\
14 & 340 & 14,25 & $4.845,00$ \\
21 & 300 & 10,00 & $3.000,00$ \\
\hline
\end{tabular}

Fonte: dados de pesquisa

\subsection{Custos}

2.2.1 Investimento Inicial (ano 0): não são considerados custos com a aquisição/venda de terra no início e final do projeto; respectivamente.

2.2.1.1 Custos de Implantação: Idem tabela C.2.

2.2.2 Custos anuais de manutenção: Idem tabelasC. 3 a C.10. 


\section{Plantio de 1 hectare de eucalipto considerando custo da terra}

3 Projeto MG3 - plantio de eucalipto considerando a compra de lenha de eucalipto pela empresafinanciadora no $1^{\circ}$ corte e incluindo o custo da terra.

\subsection{Benefícios}

\subsubsection{Receita da venda da terra no final do projeto:}

O preço médio praticado para 1 hectare de terra reflorestável na região do Vale do Rio Doce, para qual a análise está sendo realizada, segundo técnicos do Instituto Estadual de Florestas, em novembro de 1999, foi de R\$ 400,00 .

3.1.2 Receita das vendas dos produtos da exploração florestal: Idem tabela C.1

3.2 Custos

3.2.1 Investimento Inicial (ano 0)

3.2.1.1 Compra da terra: Idem 3.1.1

3.2.1.2 Custo de implantação: Idem tabela C.2.

3.2.2 Custos anuais de manutenção: Idem tabelas C.3 a C.10.

4 Projeto MG4 - Plantio de eucalipto considerando a compra da lenha de eucalipto pela empresa financiadora no $1^{\circ}$ e $2^{\circ}$ cortes e incluindo o custo da terra.

\subsection{Benefícios}

4.1.1 Receita da venda da terra no final do projeto: Idem 3.1.1

4.1.2 Receita da venda dos produtos da exploração florestal: Idem tabela C.11.

\subsection{Custos}

\subsubsection{Investimento Inicial (ano 0)}

4.2.1.1 Compra da terra: Idem 3.1.1

4.2.1.2 Custo de Implantação: Idem tabela C.2.

4.2.2 Custos anuais de manutenção : Idem tabela C.3 a C.10. 
Apêndice 4 - Informações gerais sobre as receitas e custos de um projeto de reflorestamento com eucalipto em pequena escala no Estado do Paraná 


\section{Plantio de 1 hectare de eucalipto sem considerar o custo da terra}

1. Projeto PR1 - plantio do eucalipto sem considerar o custo da terra e com doação de mudas ao produtor rural.

A densidade de plantio considerada é de 1666 plantas/ha, sob espaçamento $3 \times 2$ metros. As operações, os coeficientes técnicos sobre o uso de máquinas, insumos e mão-de-obra e a produtividade considerados foram fundamentados em Rodighieri \& Pinto.(1997). O preço da lenha de eucalipto, referente à novembro de 1999, foi coletado junto ao IAP e foi cotado à $\mathrm{R} \$ 7,50 / \mathrm{m}^{3}$. Os preços pagos pelo agricultor nos demais insumos (formicida, herbicida, mudas e adubo), mão-de-obra e aluguel de trator foram coletados junto ao Departamento de Economia Rural da Secretaria de Abastecimento do Paraná (DERAL/SEAB). O custo do conjunto mecanizado foi calculado com base no Agrianual (2000), conforme Apêndice 5.

\subsection{Benefícios}

\subsubsection{Receita da venda dos produtos da exploração florestal:}

Tabela D.1 - Receita das vendas dos produtos da exploração florestal de 1 ha de eucalipto, com doação de mudas no estado do Paraná.

\begin{tabular}{c|c|c|c}
\hline Idade (anos) & Volume Retirado $\left(\mathbf{m}^{3} / \mathbf{h a}\right)^{*}$ & Preço Unitário $\left(\mathbf{R} \mathbf{/ \mathbf { m } ^ { 3 }}\right)$ & Receita Total (R\$) \\
\hline 7 & 225 & 7,50 & $1.687,50$ \\
14 & 215 & 7,50 & $1.612,50$ \\
21 & 192 & 7,50 & $1.440,00$ \\
\hline
\end{tabular}

Fonte: $\quad$ Ridigheri \& Pinto (1997) e dados de pesquisa

* Os autores consideraram a produtividade e preço do metro cúbico. A taxa de conversão é : $0,7 \mathrm{~m}^{3}=1$ st. Portanto, um volume de $225 \mathrm{~m}^{3}$ de lenha é igual a 321 st de lenha.

\subsection{Custos}

\subsubsection{Investimento Inicial (ano 0)}

1.2.1.1 Custo de Implantação: não estão sendo considerados custos com a aquisição/venda de terra no início e final do investimento.

Tabela D.2 - Custos de implantação (ano 0) de 1 hectare de eucalipto com doação de mudas no estado do.Paraná.

\begin{tabular}{l|c|c|c|c}
\hline \multicolumn{1}{c|}{ Item } & Unidade/ha & Quantidade & Preço Unitário (R\$) & Valor Total (R\$) \\
\hline 1 Mecanização & & & & \\
Aração & Hora-trator & 1 & 32,47 & 32,47 \\
Gradeação & Hora-trator & 2 & 13,07 & 26,14 \\
Sulcamento/Ad. Base & Hora-trator & 1 & 15,93 & 15,93 \\
2 Mão-de-obra & & & & \\
Combate a formigas & Homem-dia & 1 & 9,04 & 9,04 \\
Plantio & Homem-dia & 3 & 9,04 & 27,12 \\
Replantio (10\%) & Homem-dia & 1 & 9,04 & 27,12 \\
Capina manual & Homem-dia & 3 & 9,04 & 9,04 \\
Roçada manual & Homem-dia & 1 & 9,04 & 18,08 \\
Adubação & Homem-dia & 2 & 9,04 & 23,10 \\
3 Insumos & & & & 110,00 \\
Formicidas & kg & 2,5 & 9,24 & $\mathbf{3 0 7 , 0 8}$ \\
NPK & kg & 250 & 0,44 & \\
\hline Total & & & & \\
\hline
\end{tabular}

Fonte: Ridigheri \& Pinto (1997), DERAL/SEAB e dados de pesquisa 


\subsection{2 - Custos anuais de manutenção}

Tabela D.3 - Custo de manutenção do $1^{\circ}$ ano, de 1 hectare plantado com eucalipto, com doação de mudas no estado do Paraná

\begin{tabular}{l|c|c|c|c}
\hline \multicolumn{1}{c|}{ Item } & Unidade/ha & Quantidade & Preço Unitário (R\$) & Valor total (R\$) \\
\hline $\begin{array}{l}\text { 1. Mecanização } \\
\text { Aplicação de herbicidas }\end{array}$ & Hora-trator & 1 & 17,55 & 17,55 \\
$\begin{array}{l}\text { 2. Mão-de-obra } \\
\text { Capina manual }\end{array}$ & Homem-dia & 2 & 9,04 & 18,08 \\
$\begin{array}{l}\text { Roçada manual } \\
\text { 3. Insumos }\end{array}$ & Homem-dia & 1 & 9,04 & 9,04 \\
Herbicidas & Litro & 4 & 9,37 & 37,48 \\
\hline Total & & & & $\mathbf{8 2 , 1 5}$ \\
\hline
\end{tabular}

Fonte: Ridigheri \& Pinto (1997), DERAL/SEAB e dados de pesquisa

Tabela D.4 - Custo de Manutenção do $2^{\circ}$ ao $6^{\circ}, 9^{\circ}$ ao $13^{\circ}$ e $16^{\circ}$ ao $20^{\circ}$ anos, de 1 hectare plantado com eucalipto, com doação de mudas no estado do Paraná

\begin{tabular}{l|c|c|c|c}
\hline \multicolumn{1}{c|}{ Item } & Unidade/ha & Quantidade & Preço Unitário (R\$) & Valor total (R\$) \\
\hline 1 Mão-de-obra & & & & \\
Capina manual & Homem-dia & 1 & 9,04 & 9,04 \\
Roçada manual & Homem-dia & 1 & 9,04 & 9,04 \\
\hline Total &. & & & $\mathbf{1 8 , 0 8}$ \\
\hline
\end{tabular}

Fonte: Ridigheri \& Pinto (1997), DERAL/SEAB e dados de pesquisa

Tabela D.5 - Custo de manutenção e exploração do $7^{\circ}$ e $14^{\circ}$ ano de 1 hectare plantado com eucalipto, com doação de mudas no estado do Paraná.

\begin{tabular}{l|c|c|c|c}
\hline \multicolumn{1}{c|}{ Item } & Unidade/ha & Quantidade & Preço Unitário (R\$) & Valor total (R\$) \\
\hline 1. Mão-de-obra & & & & \\
Adubação & Homem-dia & 1 & 9,04 & 9,04 \\
Corte raso e empilhamento & Homem-dia & 18 & 9,04 & 162,72 \\
2 Insumos & & 100 & 0,44 & 44,00 \\
NPK & & & & $\mathbf{2 1 5 , 7 6}$ \\
\hline Total & & & \\
\hline
\end{tabular}

Fonte: Ridigheri \& Pinto (1997), DERAL/SEAB e dados de pesquisa

Tabela D.6 - Custo de Manutenção do $8^{\circ}$ e $15^{\circ}$ ano de 1 hectare plantado com eucalipto, com doação de mudas no estado do Paraná.

\begin{tabular}{l|c|c|c|c}
\hline \multicolumn{1}{c|}{ Item } & Unidade/ha & Quantidade & Preço Unitário (R\$) & Valor total (R\$) \\
\hline 1. Mão-de-obra & & & & \\
Combate a formigas & Homem-dia & 1 & 9,04 & 9,04 \\
Adubação & Homem-dia & 1 & 9,04 & 9,04 \\
Desdobra & Homem-dia & 2 & 9,04 & 18,08 \\
2. Insumos & & 2 & & \\
Formicida & Litro & 100 & 9,24 & 18,48 \\
NPK & $\mathrm{kg}$ & & & 44,00 \\
\hline Total & $\cdot$ & & & $\mathbf{9 8 , 6 4}$ \\
\hline
\end{tabular}

Fonte: Ridigheri \& Pinto (1997), DERAL/SEAB e dados de pesquisa 
Tabela D.7 - Custo anual de exploração do $21^{\circ}$ ano de 1 ha plantado com eucalipto, com doação de mudas no estado do Paraná.

\begin{tabular}{l|c|c|c|c}
\hline \multicolumn{1}{c|}{ Item } & Unidade/ha & Quantidade & Preço Unitário (R\$) & Valor total (R\$) \\
\hline $\begin{array}{l}\text { 1. Mão-de-obra } \\
\text { Corte raso e empilhamento }\end{array}$ & Homem-dia & 18 & 9,04 & 162,72 \\
\hline Total & $\cdot$ & & & 162,72 \\
\hline
\end{tabular}

Fonte: Ridigheri \& Pinto (1997), DERAL/SEAB e dados de pesquisa

2. Projeto PR2 - plantio do eucalipto sem considerar o custo da terra e com aquisição de mudas pelo produtor rural.

\subsection{Benefícios}

2.1.1 Receita da venda dos produtos da exploração florestal: Idem tabela D.1.

\subsection{Custos}

2.2.1 Investimento Inicial (ano 0): não estão sendo considerados custos com a aquisição/venda de terra no início e final do projeto, respectivamente.

\subsubsection{Custo de Implantação}

Tabela D.8 - Custos de implantação (ano 0) de 1 hectare de eucalipto com aquisição de mudas no estado do Paraná.

\begin{tabular}{|c|c|c|c|c|}
\hline Item & Unidade/ha & Quantidade & Preço Unitário (R\$) & Valor Total (RS) \\
\hline $\begin{array}{ll}1 & \text { Mecanização }\end{array}$ & & & & \\
\hline Aração & Hora-trator & 1 & 32,47 & 32,47 \\
\hline Gradeação & Hora-trator & 2 & 13,07 & 26,14 \\
\hline Sulcamento/Ad. Base & Hora-trator & 1 & 15,93 & 15,93 \\
\hline 2 Mão-de-obra & & & & \\
\hline Combate a formigas & Homem-dia & 1 & 9,04 & 9,04 \\
\hline Plantio & Homem-dia & 3 & 9,04 & 27,12 \\
\hline Replantio (10\%) & Homem-dia & 1 & 9,04 & 9,04 \\
\hline Capina manual & Homem-dia & 3 & 9,04 & 27,12 \\
\hline Roçada manual & Homem-dia & 1 & 9,04 & 9,04 \\
\hline Adubação & Homem-dia & 2 & 9,04 & 18,08 \\
\hline 3 Insumos & & & & \\
\hline Mudas & unidade & 1.833 & 0,07 & 128,31 \\
\hline Formicidas & $\mathrm{kg}$ & 2,5 & 9,24 & 23,10 \\
\hline NPK & $\mathrm{kg}$ & 250 & 0,44 & 110,00 \\
\hline Total & & & & $4 \overline{35,39}$ \\
\hline
\end{tabular}

Fonte: Ridigheri \& Pinto (1997), DERAL/SEAB e dados de pesquisa

2.2.2 Custos anuais de manutenção: Idem tabelas D.3 a D.7. 
Plantio do eucalipto considerando o custo de aquisição da terra

3. Projeto PR3 - Plantio do eucalipto considerando o custo de aquisição da terra e a doação de mudas ao produtor nural.

\subsection{Benefícios}

3.3.1 Receita da venda da terra no final do projeto :

O preço médio praticado no estado do Paraná para terra mista mecanizável, segundo o Departamento de Economia Rural da Secretaria da Agricultura do Paraná, em novembro de 1999, foi cotado a R\$ 1.307,53 o hectare.

3.3.2 Receita da venda dos produtos da exploração florestal: Idem tabela D.1.

\subsection{Custos}

\subsubsection{Investimento Inicial (ano 0)}

3.2.1.1 Compra da terra: Idem 3.1.1

3.2.1.1Custo de Implantação: Idem tabela D.2.

3.2.2 Custos anuais de manutenção: Idem tabelas D.3 a D.7.

4. Projeto PR4 - plantio do eucalipto considerando o custo de aquisição da terra e a aquisição de mudas pelo produtor rural.

\subsection{Benefícios}

4.1.1 Receita da venda da terra no final do projeto: Idem 3.1.1

4.1.2 Receita da venda dos produtos da exploração florestal: Idem tabela D.1.

4.2 Custos

4.2.1 Investimento Inicial (ano 1)

4.2.1.1 Compra da terra: Idem 3.1.1

4.2.1.2 Custo de Implantação: Idem tabela D.8

4.2.2 Custos anuais de manutenção: Idem tabelas D.3 a D.7. 
Apêndice 5 - Cálculo do custo do conjunto mecanizado para plantio de eucalipto nos Estados de São Paulo e do Paraná 
Os custos dos implementos agrícolas considerados foram retirados do Agrianual 2000. "Os preços publicados nas tabelas de máquinas e implementos são praticados no mercado paulista e foram cotados em reais, durante o mês de ägosto de 1999. A conversão para a moeda norte-americana foi feita à taxa de $\mathrm{R} \$ 1,85 / \mathrm{US} \$ 1,00$ " (Agrianual, 2000, p. 89). O cálculo da capacidade efetiva (largura de trabalho $x$ velocidade de deslocamento), capacidade operacional (área $x$ eficiência de campo) e eficiência de trabalho (considerou-se $75 \%$ de eficiência do conjunto) foi fundamentada em Mialhe (1974).

\section{São Paulo -}

Foi considerado o uso de um trator de pneu de médio porte nas operações mecanizadas realizadas nas pequenas e médias propriedades rurais no Estado. Dessa maneira, tomou-se o custo do trator MF- 275 1 Massey Ferguson (75HP), trabalhando $1000 \mathrm{~h} / \mathrm{ano}$, de US\$ 8,06/hora. Considerando a conversão US\$1,85/R \$1,00 adotada pela fonte (Agrianual 2000, p. 89), temos R\$14,91 em agosto de 1999. Deflacionando pelo IGP-DI de novembro de 1999 tem-se que o custo do trator é de R\$15,81 em novembro de 1999.

\section{ARAÇÃO}

O custo do Arado fixo leve com roda/ dimensão 28 " x $6.0 \mathrm{~mm} / 3$ discos/ Marchesan (compatível com o trator considerado e com o espaçamento adotado no plantio) é de US\$ $0,22 /$ hora. Se US $\$ 1,85=R \$$ 1,00 tem-se o equivalente a R \$ 0,41/hora em agosto de 1999. Em valores de novembro de 1999, tem-se $\mathrm{R} \$ 0,44$.

A largura de trabalho do arado é de $1,5 \mathrm{~m}$ e sua velocidade média é de $5 \mathrm{Km} / \mathrm{hora}$. Assim, em uma hora são arados 0,75 hectares. Estipulando uma eficiência de trabalho de $75 \%$, tem-se que em uma hora são arados 0,56 hectares. Somando-se :

$\begin{array}{ll}\text { Trator } & \mathrm{R} \$ 15,81 \\ \text { Arado } & \mathrm{R} \$ 0,44 \\ \text { Total } & \mathrm{R} \$ 16,25 / \text { hora }\end{array}$

Se em uma hora é feito a aração de 0,56 hectares, então, para um hectare serão gastos $\mathrm{R} \$ 29,02$.

\section{GRADEAÇÃO}

O custo de uma grade niveladora Baldan com 28 discos é de US\$ 0,95/hora, ou R\$ 1,76 em agosto de 1999. Deflacionando esse valor para novembro de 1999, tem-se R\$1,87. 
A largura de trabalho da grade é de 4,0 metros e sua velocidade média é $5 \mathrm{Km} /$ hora. Dessa maneira, são gradeados 2 hectares em uma hora. Estipulando uma eficiência de trabalho de $75 \%$, tem-se a gradeação de 1,5 hectares em uma hora. Somando-se:

$\begin{array}{ll}\text { Trator } & \mathrm{R} \$ 15,81 \\ \text { Grade } & \mathrm{R} \$ 1,87 \\ \text { Total } & \mathrm{R} \$ 17,68 \text { /hora }\end{array}$

Se em uma hora é feito a gradagem de 1,5 hectares, então, para um hectare serão gastos $\mathrm{R} \$ 11,79$.

\section{SULCAMENTO/ADUBAÇÃO DE BASE}

Considerando que um sulcạdor de 1 linha leve / Marchesan custa US\$ 0,09/hora e considerando a conversão US\$1,85/R \$1,00, tem-se um custo de R\$ 0,17/hora. (Agrianual, 2000, p. 89). Deflacionando este valor para novembro de 1999 , temos $\mathrm{R} \$ 0,18$ /hora.

A largura de trabalho da grade é de 3,0 metros e sua velocidade média é de $5 \mathrm{Km} /$ hora, portanto, são sulcados/adubados 1,5 ha/hora.

Estipulando uma eficiência de trabalho de $75 \%$, tem-se o sulcamento/adubação de 1,125 hectares em uma hora. Somando-se:

Trator

$\mathrm{R} \$ 15,81$

Sulcador

$\underline{\mathrm{R} \$ 0,18}$

Total

$\mathrm{R} \$ 15,99 /$ hora

Se em uma hora se faz o sulcamento/adubação de base de 1,125 hectares, então, para um hectare serão gastos $R \$ 14,21$.

\section{ROÇADA MECANIZADA NAS ENTRELINHAS}

O custo de uma roçadeira central - RO2 2600 é de US\$ 0,37/hora ou R\$ 0,6845/hora em agosto de 1999. Deflacionando este valor para novembro de 1999 tem-se um custo de $\mathrm{R} \$ 0,73$.

A largura de trabalho da roçadeira é de $1,5 \mathrm{~m}$ e sua velocidade média de $4,5 \mathrm{Km} /$ hora, portanto, são roçados 0,675 hectares em uma hora.

Estipulando uma eficiência de trabalho de $75 \%$ é efetuada a roçada mecanizada nas entrelinhas de 0,51 hectares, em uma hora. Somando-se:

$\begin{array}{ll}\text { Trator } & \mathrm{R} \$ 15,81 \\ \text { Roçadeira } & \mathrm{R} \$ 0,73 \\ \text { Total } & \mathrm{R} \$ 16,54 \text { hora }\end{array}$


Se em uma hora se faz a roçada mecanizada de 0,51 hectares, então, para um hectare serão gastos $\mathrm{R} \$ 32,43$.

Paraná -

Segundo SEAB (1999) o valor do aluguel de trator de pneu médio (71 a $86 \mathrm{HP}$ )/ hora é de R\$ 17,74 em novembro de 1999 . Utilizou-se para cálculo do conjunto mecanizado no Paraná dados do Agrianual (2000).

\section{ARAÇÃO}

O custo do arado fixo leve com roda/ dimensão 28 " x $6.0 \mathrm{~mm} / 3$ discos/ Marchesan (compatível com o trator considerado e com o espaçamento adotado - $3 \times 2$ metros - no plantio) é de US $\$ 0,22 /$ hora. Se US\$1,85/R \$ 1,00 tem-se o equivalente a R\$ 0,41/hora em agosto de 1999 (Agrianual, 2000, p. 89). Deflacionando esse valor para novembro de 1999 , tem-se R $\$ 0,44$ /hora.

A largura de trabalho do arado é de $1,5 \mathrm{~m}$ e sua velocidade média é de $5 \mathrm{Km} / \mathrm{hora}$ Assim, em uma hora são arados 0,75 hectares. Estipulando uma eficiência de trabalho de $75 \%$, tem-se que em uma hora são arados 0,56 hectares. Somando-se :

Trator $\quad \mathrm{R} \$ 17,74$

Arado $\quad \underline{\mathrm{R} \$ 0,44}$

Total R\$ 18,18/hora

Se em uma hora é feito a aração de 0,56 hectares, então, para um hectare serão gastos $R \$ 32,47$.

\section{GRADEAÇÃO}

O custo de uma grade niveladora Baldan com 28 discos é de US $\$ 0,95 /$ hora ou R $\$ 1,76$ em agosto de 1999. Deflacionando esse valor para novembro de 1999 , tem-se $\mathrm{R} \$ 1,87$.

A largura de trabalho da grade é de 4,0 metros e sua velocidade média é $5 \mathrm{Km} /$ hora. Dessa maneira, são gradeados 2 hectares em uma hora. Estipulando uma eficiência de trabalho de $75 \%$, tem-se a gradeação de 1,5 hectares em uma hora. Somando-se:

$\begin{array}{ll}\text { Trator } & \mathrm{R} \$ 17,74 \\ \text { Grade } & \mathrm{R} \$ 1,87 \\ \text { Total } & \mathrm{R} \$ 19,61 / \text { hora }\end{array}$

Se em uma hora é feito a gradagem de 1,5 hectares, então, para um hectare serão gastos $\mathbf{R} \$ 13,07$. 


\section{SULCAMENTO/ADUBAÇÃO DE BASE}

Considerando que um sulcador de 1 linha leve/Marchesan custa US\$ 0,09/hora ou R\$ 0,17/hora em agosto de 1999. Deflacionando esse valor pelo IGP-DI, tem-se R\$ 0,18.

A largura de trabalho da grade é de 3,0 metros e sua velocidade média é de $5 \mathrm{Km} / \mathrm{hora}$, portanto, são sulcados/adubados 1,5 hectares em uma hora. Estipulando uma eficiência de trabalho de $75 \%$, tem-se o sulcamento/adubação de 1,125 hectares em uma hora. Somando-se:

Trator

$\mathrm{R} \$ 17,74$

Sulcador

$$
\underline{\mathrm{R} \$ 0,18}
$$

Total

$\mathrm{R} \$ 17,92 /$ hora

Se em uma hora se faz o sulcamento/adubação de base de 1,125 hectares, então, para um hectare serão gastos R\$15,93.

\section{APLICAÇÃO DE HERBICIDA}

O custo do pulverizador de barras $12 \mathrm{~m}$ - Montana SLCap 400I/Berthoud é de US\$ 1,02/hora ou $\mathrm{R} \$ 1,89 /$ hora, em valores de agosto de 1999 . Deflacionando pelo IGP-DI tem-se $\mathrm{R} \$ 2,00 /$ hora em valores de novembro de 1999.

A largura de trabalho do pulverizador é de 3,0 metros e $5 \mathrm{Km} / \mathrm{hora}$, portanto é feito a aplicação de herbicida em 1,5 hectares em uma hora. Estipulando uma eficiência de trabalho de $75 \%$, tem-se 1,125 ha/hora.

$\begin{array}{ll}\text { Trator } & \mathrm{R} \$ 17,74 \\ \text { Pulverizador } & \mathrm{R} \$ 2,00 \\ \text { Total } & \mathrm{R} \$ 19,74 / \text { hora }\end{array}$

Se em uma hora se faz a aplicação de herbicida de 1,125 hectares, então, para um hectare serão gastos R\$17,55. 
Apêndice 6 - Informações para a elaboração de cenários (otimistas ou pessimistas) para os projetos de reflorestamento com eucalipto 


\section{SÃo PaUlo}

\subsection{Cenários Otimistas}

1.1.1 Segundo Elias (1994), em algumas regiões do Estado de São Paulo a produtividade do eucalipto chega a ser de 70 st/ha/ano, o que representa uma produtividade $40 \%$ acima da produtividade florestal considerada nos projetos analisados no presente trabalho. Assim, supondo este aumento na produtividade florestal, as receitas das vendas dos produtos da exploração florestal de 1 hectare com eucalipto no Estado de São Paulo passariam a ser as apresentadas na tabela:

Tabela F.1 - Receita das vendas de subprodutos da exploração florestal de 1 hectare com eucalipto incorporando o aumento da produtividade florestal.

\begin{tabular}{c|c|c|c}
\hline Ano & Volume retirado (st/ha) & Preço Unitário (R\$/st) & Receita Total (R\$) \\
\hline 7 & 490,00 & 7,50 & $3.675,00$ \\
14 & 434,00 & 7,50 & $3.255,00$ \\
21 & 392,00 & 7,50 & $2.940,00$ \\
\hline
\end{tabular}

Fonte: dados de pesquisa e valores calculados pelo autor

1.1.2 Segundo Machado (2000), no Estado de São Paulo o preço da lenha de eucalipto pode aumentar $66,67 \%$ em relação ao preço considerado no projeto analisado. Supondo esse aumento, as receitas das vendas dos produtos de exploração de 1 hectare com eucalipto no Estado de São Paulo passariam a ser:

Tabela F.2 - Receita das vendas de subprodutos da exploração florestal de 1 hectare com eucalipto incorporando o aumento no preço da lenha de eucalipto.

\begin{tabular}{c|c|c|c}
\hline Ano & Volume retirado (st/ha) & Preço Unitário (R\$/st) & Receita Total (R\$) \\
\hline 7 & 350 & 12,50 & $4.375,00$ \\
14 & 310 & 12,50 & $3.875,00$ \\
21 & 280 & 12,50 & $3.500,00$ \\
\hline
\end{tabular}

Fonte: dados de pesquisa e valores calculados pelo autor

\subsection{Cenários Pessimistas}

1.2.1 Segundo Elias (1994), em algumas regiões do Estado de São Paulo a produtividade do Eucalipto é de $35 \mathrm{st} /$ ha/ano em média, ou seja, 30\% menor em relação a produtividade considerada nos projetos aqui analisados. Supondo essa redução na produtividade florestal, as receitas das vendas dos produtos da exploração de 1 hectare com eucalipto no Estado de São Paulo passariam a ser: 
Tabela F.3 - Receita das vendas de subprodutos da exploração florestal de 1 hectare com eucalipto incorporando a redução da produtividade florestal.

\begin{tabular}{c|c|c|c}
\hline Ano & Volume retirado (st/ha) & Preço Unitário (R\$/st) & Receita Total (R\$) \\
\hline 7 & 245,00 & 7,50 & $1.837,50$ \\
14 & 217,00 & 7,50 & $1.627,50$ \\
21 & 196,00 & 7,50 & $1.470,00$ \\
\hline
\end{tabular}

Fonte: dados de pesquisa e valores calculados pelo autor

1.2.2 Segundo Machado (2000), os valores praticados no Estado de São Paulo para o preço da lenha de eucalipto apresentam variação de $66,67 \%$ em relação ao preço considerado na análise determinista. Supondo essa queda, as receitas das vendas dos produtos da exploração de 1 ha de eucalipto passariam a ser:

Tabela F.4 - Receita das vendas de subprodutos da exploração florestal de 1 hectare com eucalipto incorporando o decréscimo no preço da lenha de eucalipto.

\begin{tabular}{c|c|c|c}
\hline Ano & Volume retirado (st/ha) & Preço Unitário (R\$/st) & Receita Total (R\$) \\
\hline 7 & 350,00 & 2,50 & 875,00 \\
14 & 310,00 & 2,50 & 775,00 \\
21 & 280,00 & 2,50 & 700,00 \\
\hline
\end{tabular}

Fonte: dados de pesquisa e valores calculados pelo autor

\section{PARANÁ}

\subsection{Cenários Otimistas}

2.1.1 Segundo Rodigheri \& Pinto (1997), as empresas reflorestadoras que utilizam maior nível de adubação e realizam mais eficientemente as operações de cultivo conseguem, em algumas regiões do Estado do Paraná, alcançar rendimentos superiores a $40 \mathrm{~m}^{3} / \mathrm{ha} / \mathrm{ano}$. Supondo um aumento de $24,44 \%$ na produtividade, as receitas das vendas dos produtos de exploração florestal de 1 hectare com eucalipto passariam a ser as contidas na tabela abaixo:

Tabela F.5 - Receita das vendas de subprodutos da exploração florestal de 1 hectare com eucalipto incorporando o aumento da produtividade florestal.

\begin{tabular}{c|c|c|c}
\hline Ano & Volume retirado $\left(\mathrm{m}^{3} / \mathrm{ha}\right)$ & Preço Unitário $\left(\mathrm{R} \$ / \mathrm{m}^{3}\right)$ & Receita Total $(\mathrm{R} \$)$ \\
\hline 7 & 280,00 & 7,50 & $2.100,00$ \\
14 & 267,55 & 7,50 & $2.006,63$ \\
21 & 238,93 & 7,50 & $1.791,98$ \\
\hline
\end{tabular}

Fonte: dados de pesquisa e valores calculados pelo autor 
2.1.2 Segundo Dossa et al. (2000), nos últimos 10 anos observa-se uma variação de $20 \%$ no preço da lenha de eucalipto. Supondo assim um aumento de $20 \%$ no preço da lenha de eucalipto, as receitas das vendas dos produtos de exploração florestal de 1 hectare com eucalipto passariam a ser as contidas na tabela abaixo:

Tabela F.6 - Receita das vendas de subprodutos da exploração florestal de 1 hectare com eucalipto incorporando o aumento do preço da lenha de eucalipto.

\begin{tabular}{c|c|c|c}
\hline Ano & Volume retirado $\left(\mathrm{m}^{3} / \mathrm{ha}\right)$ & Preço Unitário $\left(\mathrm{R} \$ / \mathrm{m}^{3}\right)$ & Receita Total $(\mathrm{R} \$)$ \\
\hline 7 & 225,00 & 9,00 & $2.025,00$ \\
14 & 215,00 & 9,00 & $1.935,00$ \\
21 & 192,00 & 9,00 & $1.728,00$ \\
\hline
\end{tabular}

Fonte: dados de pesquisa e valores calculados pelo autor

\subsection{Cenários Pessimistas}

2.2.1 Segundo Dossa et al. (2000), observa-se uma queda da produtividade florestal de $20 \%$ nos últimos 10 anos. Supondo assim uma queda de $20 \%$ na produtividade, as receitas das vendas dos produtos da exploração florestal de 1 hectare com eucalipto no Estado do Paraná passariam a ser:

Tabela F.7 - Receita das vendas de subprodutos da exploração florestal de 1 hectare com eucalipto incorporando a redução da produtividade florestal.

\begin{tabular}{c|c|c|c}
\hline Ano & Volume retirado $\left(\mathrm{m}^{3} / \mathrm{ha}\right)$ & Preço Unitário $\left(\mathrm{R} \$ \mathrm{~m}^{3}\right)$ & Receita Total $(\mathrm{R} \$)$ \\
\hline 7 & 180,00 & 7,50 & $1.350,00$ \\
14 & 172,00 & 7,50 & $1.290,00$ \\
21 & 153,60 & 7,50 & $1.152,00$ \\
\hline
\end{tabular}

Fonte: dados de pesquisa e valores calculados pelo autor

2.2.2 Segundo Dossa et al. (2000), observa-se uma queda de $20 \%$ nos preços da lenha de eucalipto. Supondo esta queda, as receitas das vendas dos produtos da exploração florestal de 1 hectare com eucalipto no Estado do Paraná passariam a ser:

Tabela F.8 - Receita das vendas de subprodutos da exploração florestal de 1 hectare com eucalipto incorporando o decréscimo do preço da lenha de eucalipto.

\begin{tabular}{c|c|c|c}
\hline Ano & Volume retirado $\left(\mathrm{m}^{3} / \mathrm{ha}\right)$ & Preço Unitário $\left(\mathrm{R} \$ / \mathrm{m}^{3}\right)$ & Receita Total $(\mathrm{R} \$)$ \\
\hline 7 & 225,00 & 6,00 & $1.350,00$ \\
14 & 215,00 & 6,00 & $1.290,00$ \\
21 & 192,00 & 6,00 & $1.152,00$ \\
\hline
\end{tabular}

Fonte: dados de pesquisa e valores calculados pelo autor 


\subsection{Cenários Otimistas}

3.1.1 Segundo técnicos do IEF, a produtividade alcançada na região do Vale do Rio Doce pode chegar a $650 \mathrm{st} /$ ha até o primeiro ano de corte ${ }^{18}$. Dessa maneira, tem-se um aumento de $62,5 \% \mathrm{em}$ relação a produtividade florestal considerada nos projetos analisados. Supondo esse aumento nas produtividades, as receitas das vendas dos produtos da exploração florestal de 1 hectare com eucalipto passariam a ser as contidas na tabela abaixo.

Tabela F.9 - Receita das vendas de subprodutos da exploração florestal de 1 hectare com eucalipto incorporando o aumento da produtividade florestal

\begin{tabular}{c|c|c|c}
\hline Ano & Volume retirado (st/ha) & Preço Unitário (R\$/st) & Receita Total (R\$) \\
\hline 7 & 609,38 & 14,25 & $8.683,67$ \\
14 & 552,50 & 10,00 & $5.525,00$ \\
21 & 487,50 & 10,00 & $4.875,00$ \\
\hline
\end{tabular}

Fonte: dados de pesquisa e valores calculados pelo autor

3.1.2 Segundo técnicos do IEF, o preço máximo alcançado pela lenha de eucalipto é de $\mathrm{R} \$ 11,00 / \mathrm{st}$. Dessa maneira, tem-se um aumento de $10 \%$ em relação ao preço de lenha de eucalipto considerado nos projetos aqui analisados. Supondo esse aumento as receitas das vendas do produtos da exploração florestal de 1 hectare com eucalipto passariam a ser:

Tabela F.10 - Receita das vendas de subprodutos da exploração florestal de 1 hectare com eucalipto incorporando o aumento no preço da lenha de eucalipto.

\begin{tabular}{c|c|c|c}
\hline Ano & Volume retirado (st/ha) & Preço Unitário (R\$/st) & Receita Total (R\$) \\
\hline 7 & 375,00 & 14,25 & $5.343,75$ \\
14 & 340,00 & 11,00 & $3.740,00$ \\
21 & 300,00 & 11,00 & $3.300,00$ \\
\hline
\end{tabular}

Fonte: dados de pesquisa e valores calculados pelo autor

\subsection{Cenários Pessimistas}

3.2.1 Segundo técnicos do IEF, a menor produtividade alcançada na região do Vale do Rio Doce pode chegar à $70 \%$ da produtividade considerada nos projetos aqui analisados para o Estado de Minas Gerais. Supondo essa queda, as receitas das vendas dos produtos da exploração florestal de 1 hectare com eucalipto passariam a ser:

\footnotetext{
${ }^{18}$ No entanto, $6,25 \%$ dessa produção fica com a empresa fomentadora.
} 
Tabela F.11 - Receita das vendas de subprodutos da exploração florestal de 1 hectare com eucalipto incorporando a redução da produtividade florestal.

\begin{tabular}{c|c|c|c}
\hline Ano & Volume retirado (st/ha) & Preço Unitário (R\$/st) & Receita Total (R\$) \\
\hline 7 & 262,50 & 14,25 & $3.740,63$ \\
14 & 238,00 & 10,00 & $2.380,00$ \\
21 & 210,00 & 10,00 & $2.100,00$ \\
\hline
\end{tabular}

Fonte: dados de pesquisa e valores calculados pelo autor

3.2.2 Segundo técnicos do IEF, o preço da lenha de eucalipto pode decrescer de $40 \%$ em relação ao preço considerado nos projetos aqui analisados para o Estado de Minas Gerais. Supondo essa queda, as receitas das vendas dos produtos da exploração florestal de 1 hectare com eucalipto passariam a ser:

Tabela F.12 - Receita das vendas de subprodutos da exploração florestal de 1 hectare com eucalipto incorporando o decréscimo do preço da lenha de eucalipto.

\begin{tabular}{c|c|c|c}
\hline Ano & Volume retirado (st/ha) & Preço Unitário (R\$/st) & Receita Total (R\$) \\
\hline 7 & 375,00 & 14,25 & $5.343,75$ \\
14 & 340,00 & 6,00 & $2.040,00$ \\
21 & 300,00 & 6,00 & $1.800,00$ \\
\hline
\end{tabular}

Fonte: dados de pesquisa e valores calculados pelo autor 
Apêndice 7 - Fluxo de caixa, informações gerais sobre as receitas e custos e estimativa dos indicadores de avaliação econômica para os projetos MG1, MG2, MG3 e MG4 incluindo a aquisição de mudas e insumos 


\section{FLUXO DE CAIXA}

Para ef́eito de comparação, considera-se a possibilidade de existir no Programa Fazendeiro Florestal a aquisição pelo produtor rural de todos os insumos necessários ao plantio de eucalipto. Assim, acrescentando aos projetos MG1, MG2, MG3 E MG4 esses custos, tem-se os seguintes fluxos de caixa:

Tabela G.1 - Fluxo de caixa dos projetos de plantio de 1 ha de eucalipto em associação empresafazendeiro florestal, sem incluir o custo da terra e com aquisição de mudas e insumos pelo produtor rural valores expressos em reais (R\$) de novembro de 1999 - projetos MG1 E MG2.

\begin{tabular}{|c|c|c|c|c|c|c|}
\hline \multirow[b]{2}{*}{ ANOS } & \multicolumn{3}{|c|}{ MG1 } & \multicolumn{3}{|c|}{ MG2 } \\
\hline & CUSTOS & BENEFICIOS & $\begin{array}{c}\text { FLUXO } \\
\text { LÍQUIDO }\end{array}$ & CUSTOS & BENEFICIOS & $\begin{array}{c}\text { FLUXO } \\
\text { LÍQUIDO }\end{array}$ \\
\hline 0 & 669,34 & 0 & $-669,34$ & 669,34 & 0 & $-669,34$ \\
\hline 1 & 385,00 & 0 & $-385,00$ & 385,00 & 0 & $-385,00$ \\
\hline 2 & 100,35 & 0 & $-100,35$ & 100,35 & 0 & $-100,35$ \\
\hline 3 & 33,20 & 0 & $-33,20$ & 33,20 & 0 & $-33,20$ \\
\hline 4 & 87,75 & 0 & $-87,75$ & 87,75 & 0 & $-87,75$ \\
\hline 5 & 87,75 & 0 & $-87,75$ & 87,75 & 0 & $-87,75$ \\
\hline 6 & 87,75 & 0 & $-87,75$ & 87,75 & 0 & $-87,75$ \\
\hline 7 & $1.762,75$ & $5.343,75$ & $3.581,00$ & $1.762,75$ & $5.343,75$ & $3.581,00$ \\
\hline 8 & 385,00 & 0 & $-385,00$ & 385,00 & 0 & $-385,00$ \\
\hline 9 & 100,35 & 0 & $-100,35$ & 100,35 & 0 & $-100,35$ \\
\hline 10 & 33,20 & 0 & $-33,20$ & 33,20 & 0 & $-33,20$ \\
\hline 11 & 87,75 & 0 & $-87,75$ & 87,75 & 0 & $-87,75$ \\
\hline 12 & 87,75 & 0 & $-87,75$ & 87,75 & 0 & $-87,75$ \\
\hline 13 & 87,75 & 0 & $-87,75$ & 87,75 & 0 & $-87,75$ \\
\hline 14 & $1.447,75$ & $3.400,00$ & $1.952,25$ & $1.447,75$ & $4.845,00$ & $3.397,25$ \\
\hline 15 & 385,00 & 0 & $-385,00$ & 385,00 & 0 & $-385,00$ \\
\hline 16 & 100,35 & 0 & $-100,35$ & 100,35 & 0 & $-100,35$ \\
\hline 17 & 33,20 & 0 & $-33,20$ & 33,20 & 0 & $-33,20$ \\
\hline 18 & 87,75 & 0 & $-87,75$ & 87,75 & 0 & $-87,75$ \\
\hline 19 & 87,75 & 0. & $-87,75$ & 87,75 & 0 & $-87,75$ \\
\hline 20 & 87,75 & 0 & $-87,75$ & 87,75 & 0 & $-87,75$ \\
\hline 21 & $1.287,75$ & $3.000,00$ & $1.712,25$ & $1.287,75$ & $3.000,00$ & $1.712,25$ \\
\hline
\end{tabular}

Fonte: valores calculados pelo autor 
Tabela G.2 - Fluxo de caixa dos projetos de plantio de 1 ha de eucalipto em associação empresafazendeiro florestal, sem incluir o custo da terra e com aquisição de mudas e insumos pelo produtor rural valores expressos em reais (R\$) de novembro de 1999 - projetos MG3 E MG4.

\begin{tabular}{|c|c|c|c|c|c|c|}
\hline \multirow[b]{2}{*}{ ANOS } & \multicolumn{3}{|c|}{ MG3 } & \multicolumn{3}{|c|}{ MG4 } \\
\hline & CUSTOS & BENEFICIOS & $\begin{array}{c}\text { FLUXO } \\
\text { LÍQUIDO }\end{array}$ & CUSTOS & BENEFICIOS & $\begin{array}{c}\text { FLUXO } \\
\text { LÍQUIDO }\end{array}$ \\
\hline 0 & $1.069,34$ & 0 & $-1.069,34$ & $1.069,34$ & 0 & $-1.069,34$ \\
\hline 1 & 385,00 & 0 & $-385,00$ & 385,00 & 0 & $-385,00$ \\
\hline 2 & 100,35 & $0^{\circ}$ & $-100,35$ & 100,35 & 0 & $-100,35$ \\
\hline 3 & 33,20 & 0 & $-33,20$ & 33,20 & 0 & $-33,20$ \\
\hline 4 & 87,75 & 0 & $-87,75$ & 87,75 & 0 & $-87,75$ \\
\hline 5 & 87,75 & 0 & $-87,75$ & 87,75 & 0 & $-87,75$ \\
\hline 6 & 87,75 & 0 & $-87,75$ & 87,75 & 0 & $-87,75$ \\
\hline 7 & $1.762,75$ & $5.343,75$ & $3.581,00$ & $1.762,75$ & $5.343,75$ & $3.581,00$ \\
\hline 8 & 385,00 & 0 & $-385,00$ & 385,00 & 0 & $-385,00$ \\
\hline 9 & 100,35 & 0 & $-100,35$ & 100,35 & 0 & $-100,35$ \\
\hline 10 & 33,20 & 0 & $-33,20$ & 33,20 & 0 & $-33,20$ \\
\hline 11 & 87,75 & 0 & $-87,75$ & 87,75 & 0 & $-87,75$ \\
\hline 12 & 87,75 & 0 & $-87,75$ & 87,75 & 0 & $-87,75$ \\
\hline 13 & 87,75 & 0 & $-87,75$ & 87,75 & 0 & $-87,75$ \\
\hline 14 & $1.447,75$ & $3.400,00$ & $1.952,25$ & $1.447,75$ & $4.845,00$ & $3.397,25$ \\
\hline 15 & 385,00 & 0 & $-385,00$ & 385,00 & 0 & $-385,00$ \\
\hline 16 & 100,35 & 0 & $-100,35$ & 100,35 & 0 & $-100,35$ \\
\hline 17 & 33,20 & 0. & $-33,20$ & 33,20 & 0 & $-33,20$ \\
\hline 18 & 87,75 & 0 & $-87,75$ & 87,75 & 0 & $-87,75$ \\
\hline 19 & 87,75 & 0 & $-87,75$ & 87,75 & 0 & $-87,75$ \\
\hline 20 & 87,75 & 0 & $-87,75$ & 87,75 & 0 & $-87,75$ \\
\hline 21 & $1.287,75$ & $3.400,00$ & $2.112,25$ & $1.287,75$ & $3.400,00$ & $2.112,25$ \\
\hline
\end{tabular}

Fonte: valores calculados pelo autor

\section{INFORMAÇÕES GERAIS SOBRE AS RECEITAS E CUSTOS}

\section{Plantio de 1 hectare de eucalipto sem considerar o custo da terra}

1. Projeto MG1 - plantio de eucalipto considerando a compra da madeira de eucalipto pela empresafinanciadora no $1^{0}$ corte. 
São consideradas aqui as mesmas condições do projeto MG1. Admite-se, assim, que as receitas obtidas são iguais aquelas da tabela 1 do apêndice 3 . O custo de exploração também é o mesmo (observe a tabela 10 do apêndice 3 ).

\subsection{Benefícios}

\subsubsection{Receita da venda dos produtos da exploração florestal}

Considera-se que no $1^{\circ}$ corte a empresa fomentadora (empresa de celulose) paga pelo estéreo de madeira mais do que se consegue no $2^{\circ}$ e $3^{\circ}$ corte, onde se vende o produto como lenha.

Tabela G.3 - Receita da venda da madeira de eucalipto proveniente da exploração de 1 hectare , considerando a compra da madeira de eucalipto pela empresa financiadora no $1^{\circ}$ corte.

\begin{tabular}{c|c|c|c}
\hline Idade (anos) & Volume Retirado (st/ha) & Preço Unitário (R\$/st) & Receita Total (R\$) \\
\hline 7 & $375^{*}$ & 14,25 & $5.343,75$ \\
14 & 340 & 10,00 & $3.400,00$ \\
21 & 300 & 10,00 & $3.000,00$ \\
\hline
\end{tabular}

Fonte: dados de pesquisa

* Apesar de ser retirado $400 \mathrm{st} / \mathrm{ha}, 25 \mathrm{st} / \mathrm{ha}$ são entregues como pagamento aos insumos e mudas oferecidas pela empresa financiadora na implantação da cultura.

\subsection{Custos}

1.2.1 Investimento Inicial (ano 0): ‘não estão sendo considerados custos com a aquisição/venda de terra no início e final do projeto, respectivamente.

\subsubsection{Custo de Implantação}

Tabela G.4- Custos de implantação (ano 0) de 1 hectare de eucalipto com aquisição das mudas e insumos pelo produtor rural.

\begin{tabular}{l|c|c|c|c}
\hline \multicolumn{1}{c|}{ Item } & Unidade/ha & Quantidade & Preço Unitário (RS) & Valor Total (RS) \\
\hline 1 Mão-de-obra & & & & \\
Const. manual aceiro & Homem-hora & 5,7 & 1,5 & 8,55 \\
Roçada manual & Homem-hora & 12,5 & 1,5 & 18,75 \\
Queima & Homem-hora & 1,5 & 1,5 & 2,25 \\
Capina química & Homem-hora & 14 & 1,5 & 21,00 \\
$\mathbf{1}^{\circ}$ Combate a formiga & Homem-hora & 7,8 & 1,5 & 11,70 \\
Encoivara/queima & Homem-hora & 3 & 1,5 & 4,50 \\
Alinhar/marcar & Homem-hora & 9 & 1,5 & 13,50 \\
Covear & Homem-hora & 22 & 1,5 & 33,00 \\
$2^{\circ}$ Combate a formiga & Homem-hora & 7,8 & 1,5 & 11,70 \\
Adubar & Homem-hora & 12 & 1,5 & 18,00 \\
Recebimento/manter mudas & Homem-hora & 2,5 & 1,5 & 3,75 \\
Plantar & Homem-hora & 22 & 1,5 & 33,00 \\
$3^{0}$ Combate a formiga & Homem-hora & 7,8 & 1,5 & 11,70 \\
Replantio & Homem-hora & 15 & 1,5 & 22,50 \\
Const. cerca & Km & 0,03 & 1450 & 43,50 \\
Abertura de estradas & Homem-equip & 2 & 40 & 80,00 \\
2 Insumos & & & & 29,58 \\
Formicida & Kg & 8,45 & 3,50 & 68,00 \\
Herbicida & Litro & 4,0 & 17,00 & 43,00 \\
NPK & Kg & 100 & 0,43 & 16,00 \\
Mudas de semente & Mil & 320 & 0,05 & 175,36 \\
Mudas de clone & Mil & 1.280 & 0,137 & $\mathbf{6 6 9 , 3 4}$ \\
\hline Total & & & & \\
\hline
\end{tabular}




\subsection{2 - Custos anuais de manutenção}

Tabela G.5 - Custo de Manutenção do $1^{\circ}$, $8^{\circ}$ e $15^{\circ}$ anos, de 1 hectare plantado com eucalipto, com doação dos insumos pela empresa financiadora.

\begin{tabular}{l|c|c|c|c}
\hline \multicolumn{1}{c|}{ Item } & Unidade/há & Quantidade & Preço Unitário (R\$) & Valor total (R\$) \\
\hline 1 Mão-de-Obra & & & & \\
Conserv manual aceiro & Homem-hora & 3,9 & 1,5 & 5,85 \\
Combate a formiga & Homem-hora & 4,5 & 1,5 & 6,75 \\
Comb.sistemático a formiga & Homem-hora & 2 & 1,5 & 3,00 \\
Capina manual & Homem-hora & 7,5 & 1,5 & 11,25 \\
Capina química & Homem-hora & 22,5 & 1,5 & 33,75 \\
Adubar cobertura & Homem-hora & 10 & 1,5 & 15,00 \\
Adubar cobertura & Homem-hora & 10 & 1,5 & 15,00 \\
Coroamento & Homem-hora & 37,50 & 1,5 & 56,25 \\
2 Insumos & & & & \\
Formicida & $\mathrm{Kg}$ & 9,1 & 3,5 & 31,85 \\
Herbicida & $\mathrm{Litro}$ & 2,0 & 17,0 & 34,00 \\
Fosfato & $\mathrm{Kg}$ & 250 & $\mathbf{0 , 3 1}$ & $\mathbf{7 7 , 5 0}$ \\
KCL+B & $\mathrm{Kg}$ & 200 & 0,474 & 94,80 \\
\hline Total & & & & $\mathbf{3 8 5 , 0 0}$ \\
\hline
\end{tabular}

Fonte: dados de pesquisa

Tabela G.6 - Custo de Manutenção do $2^{\circ}$, $9^{\circ}$ e $16^{\circ}$ anos, de 1 hectare plantado com eucalipto, com aquisição dos insumos pelo produtor rural.

\begin{tabular}{l|c|c|c|c}
\hline \multicolumn{1}{c|}{ Item } & Unidade/ha & Quantidade & Preço Unitário (R\$) & Valor total (R\$) \\
\hline $\mathbf{1}$ Mão-de-Obra & & & & \\
Conserv. manual aceiro & Homem-hora & 3,9 & 1,5 & 5,85 \\
Roçada manual & Homem-hora & 6,0 & 1,5 & 9,00 \\
Combate a formiga & Homem-hora & 4,5 & 1,5 & 6,75 \\
Capina química & Homem-hora & 15 & 1,5 & 22,5 \\
2 Insumos & Litro & 3 & 17 & 51,00 \\
Herbicida & $\mathrm{Kg}$ & 1,5 & 3,5 & 5,25 \\
Formicida & & & & $\mathbf{1 0 0 , 3 5}$ \\
\hline Total & & &
\end{tabular}

Fonte: dados de pesquisa

Tabela G.7 - Custo de manutenção do $3^{\circ}, 10^{\circ}$ e $17^{\circ}$ anos, de 1 hectare plantado com eucalipto, com aquisição dos insumos pelo produtor rural.

\begin{tabular}{l|c|c|c|c}
\hline \multicolumn{1}{c|}{ Item } & Unidade/ha & Quantidade & Preço Unitário (R\$) & Valor total (R\$) \\
\hline 1 Mão-de-Obra & & & & \\
Conserv. manual aceiro & Homem-hora & 3,9 & 1,5 & 5,85 \\
Combate a formiga & Homem-hora & 1,2 & 1,5 & 1,80 \\
Capina química & Homem-hora & 4,5 & 1,5 & 6,75 \\
2 Insumos & & & 3,5 & 3,5 \\
Formicida & $\mathrm{Kg}$ & 1,0 & 17,0 & 15,30 \\
Herbicida & Litro & 0,9 & & $\mathbf{3 3 , 2 0}$ \\
\hline Total & & & & \\
\hline
\end{tabular}

Fonte: dados de pesquisa 
Tabela G.8 - Custo de Manutenção do $4^{\circ}$ ao $7^{\circ}, 1^{\circ}$ ao $14^{\circ}$ e $18^{\circ}$ ao $21^{\circ}$ anos de 1 hectare plantado com eucalipto, com doação dos insumos pela empresa financiadora.

\begin{tabular}{l|c|c|c|c}
\hline \multicolumn{1}{c|}{ Item } & Unidade/ha & Quantidade & Preço Unitário (R\$) & Valor total (R\$) \\
\hline $\mathbf{1}$ Mão-de-Obra & & & & \\
Conserv. manual aceiro & Homem-hora & 58,50 & 1,5 & 87,75 \\
\hline Total & & & & $\mathbf{8 7 , 7 5}$ \\
\hline
\end{tabular}

Fonte: dados de pesquisa

Tabela G.9 - Custo de exploração.

\begin{tabular}{c|c|c|c|c}
\hline Ano & $\begin{array}{c}\text { Total produzido } \\
\text { (estéreo) }\end{array}$ & $\begin{array}{c}\text { Custo unitário } \\
\text { (R\$/estéreo) }\end{array}$ & Custo total (R\$) & Total (R\$) \\
\hline $7^{\circ}$ & 375 & 4,00 & $1.500,00$ & $1.675,00$ \\
\hline $14^{\circ}$ & 25 & 7,00 & 175,00 & $1.360,00$ \\
\hline $21^{\circ}$ & 340 & 4,00 & $1.360,00$ & $1.200,00$ \\
\hline
\end{tabular}

Fonte: dados de pesquisa

2. Projeto MG2 - Plantio de eucalipto considerando a compra da madeira de eucalipto pela empresa financiadora no $1^{\circ}$ e $2^{\circ}$ cortes e venda como lenha do $3^{\circ}$ corte.

\subsection{Benefícios}

\subsubsection{Receita da venda dos produtos da exploração florestal:}

Tabela G.10 - Receita da venda da madeira de eucalipto proveniente da exploração de 1 ha, considerando a compra da madeira de eucalipto pela empresa financiadora no $1^{\circ}$ e $2^{\circ}$ cortes.

\begin{tabular}{c|c|c|c}
\hline Idade (anos) & Volume Retirado (st/ha) & Preço Unitário (R\$/st) & Receita Total (R\$) \\
\hline 7 & 375 & 14,25 & $5.343,75$ \\
14 & 340 & 14,25 & $4.845,00$ \\
21 & 300 & 10,00 & $3.000,00$ \\
\hline
\end{tabular}

Fonte: dados de pesquisa

\subsection{Custos}

2.2.1 Investimento Inicial (ano 0): não são considerados custos com a aquisição/ venda de terra no início e final do projeto respectivamente.

2.2.1.1 Custos de Implantação: Idem tabela G.2 deste apêndice.

2.2.2 Custos anuais de manutenção : Idem tabelas G.3 a G.7 deste apêndice.

\section{Plantio de 1 hectare de eucalipto considerando o custo da terra}

3 Projeto MG3 - plantio de eucalipto considerando a compra de lenha de eucalipto pela empresafinanciadora no $1^{\circ}$ corte e incluindo o custo da terra. 


\subsection{Benefícios}

3.1.1 Receita da venda da terra nö final do projeto:

O preço médio praticado para 1 hectare de terra reflorestável na região do Vale do Rio Doce, para qual a análise está sendo realizada, segundo técnicos do Instituto Estadual de Florestas, em novembro de 1999, foi de R\$ 400,00 .

3.1.2 Receita das vendas dos produtos da exploração florestal: Idem tabela 1 deste apêndice.

\subsection{Custos}

\subsubsection{Investimento Inicial (ano 0)}

\subsubsection{Compra da terra: Idem 3.1.1}

3.2.1.2 Custo de implantação: Idem tabela G.2 deste apêndice.

3.2.2 Custos anuais de manutenção: Idem tabelas G.3 a G.7.

4 Projeto MG4 - Plantio de eucalipto considerando a compra da lenha de eucalipto pela empresa financiadora no $1^{\circ}$ e $2^{\circ}$ cortes e incluindo o custo da terra.

\subsection{Benefícios}

4.1.1 Receita da venda da terra no final do projeto: Idem 3.1.1

4.1.2 Receita da venda dos produtos da exploração florestal: Idem tabela G.8 deste apêndice.

\subsection{Custos}

\subsection{1 - Investimento Inicial (ano 0)}

4.2.1.1 Compra da terra: Idem 3.1.1

4.2.1.2 Custo de Implantação: Idem tabela G.2 deste apêndice

4.2.2 Custos anuais de manutenção : Idem tabela G/3 a G.7 deste apêndice. 


\section{ESTIMATIVA DOS INDICADORES DE AVALIAÇÃO PARA OS PROJETOS SELECIONADOS} - A ANÁLISE DETERMINISTA

Tabela G.11 - Valores Atuais (VA) dos projetos de reflorestamento, em R $\$ /$ ha, considerando o custo de oportunidade do capital variando entre $6 \%$ e $20 \%$ ao ano, situação em novembro de 1999 , incluindo o custo de aquisição de mudas e insumos pelo produtor rural.

\begin{tabular}{|c|c|c|c|c|}
\hline \multirow{4}{*}{$\begin{array}{l}\text { Custo de } \\
\text { oportunida- } \\
\text { de }(\%)\end{array}$} & \multicolumn{4}{|c|}{ Minas Gerais } \\
\hline & \multicolumn{2}{|c|}{ Não inclui o custo da terra } & \multicolumn{2}{|c|}{ Inclui o custo da terra } \\
\hline & $\begin{array}{l}\text { Compra somente } \\
\text { do } 1^{\circ} \text { corte }\end{array}$ & $\begin{array}{l}\text { Compra do } 1^{\circ} \text { e } 2^{0} \\
\text { corte }\end{array}$ & $\begin{array}{c}\text { Compra somente do } \\
1 \text { - corte }\end{array}$ & $\begin{array}{c}\text { Compra do } 1^{0} \text { e } 2 \\
\text { corte }\end{array}$ \\
\hline & MG1 & MG2 & MG3 & MG4 \\
\hline 6 & $1.652,00$ & $2.291,12$ & $1.369,66$ & $2.008,78$ \\
\hline 7 & $1.399,28$ & $1.959,68$ & $1.095,89$ & $1.656,29$ \\
\hline 8 & $1.177,49$ & $1.669,45$ & 856,95 & $1.348,91$ \\
\hline 9 & 982,01 & $1.414,43$ & 647,49 & $1.079,90$ \\
\hline 10 & 809,07 & $1.189,58$ & 463,12 & 843,64 \\
\hline 11 & 655,49 & 990,72 & 300,18 & 635,41 \\
\hline 12 & 518,61 & 814,29 & 155,64 & 451,31 \\
\hline 13 & 396,22 & 657,30 & 26,94 & 288,02 \\
\hline 14 & 286,45 & 517,23 & $-88,02$ & 142,76 \\
\hline 15 & 187,69 & 391,91 & $-191,06$ & 13,16 \\
\hline 16 & 98,60 & 279,51 & $-283,68$ & $-102,77$ \\
\hline 17 & 18,03 & 178,45 & $-367,17$ & $-206,75$ \\
\hline 18 & $-55,02$ & 87,39 & $-442,64$ & $-300,24$ \\
\hline 19 & $-121,39$ & 5,14 & $-511,03$ & $-384,49$ \\
\hline 20 & $-181,83$ & $-69,28$ & $-573,13$ & $-460,59$ \\
\hline
\end{tabular}

Fonte: valores calculados pelo autor

Tabela G.12 - Taxa Interna de Retorno (TIR) dos projetos de reflorestamento com eucalipto - situação em novembro de 1999, incluindo a aquisição de mudas e insumos pelo produtor rural.

\begin{tabular}{ccccc}
\hline & \multicolumn{4}{c}{ Minas Gerais } \\
\cline { 2 - 5 } & \multicolumn{2}{c}{ Não inclui o custo da terra } & \multicolumn{2}{c}{ Inclui o custo da terra } \\
\cline { 2 - 5 } & $\begin{array}{c}\text { Compra somente } \\
\text { do } 1^{\circ} \text { corte }\end{array}$ & $\begin{array}{c}\text { Compra do } 1^{\mathbf{0}} \text { e } 2^{\circ} \\
\text { corte }\end{array}$ & $\begin{array}{c}\text { Compra somente do } \\
1^{\circ} \text { corte }\end{array}$ & $\begin{array}{c}\text { Compra do 1ㅇ } 2^{\circ}{ }^{\circ} \\
\text { corte }\end{array}$ \\
\cline { 2 - 5 } & MG1 & MG2 & MG3 & MG4 \\
\hline TIR & 17,24 & 19,07 & 13,22 & 15,11 \\
\hline
\end{tabular}

Fonte: valores calculados pelo autor 
Apêndice 8 - Aspectos gerais na análise de risco pela simulação de Monte Carlo 
Quadro H.1 - Definições das variáveis para a análise de risco dos projetos de investimento em reflorestamentos com eucalipto no Estado de São Paulo.

\begin{tabular}{|c|c|c|c|c|}
\hline \multirow[t]{2}{*}{ Variável } & \multicolumn{3}{|c|}{ Valores } & \multirow[t]{2}{*}{ Definição da variável } \\
\hline & Mínimo & Médio & Máximo & \\
\hline Preço da lenha (st) & 2,50 & 7,50 & 12,50 & $\begin{array}{l}\text { Variação observada para o preço da lenha de } \\
\text { eucalipto no Estado de São Paulo }\end{array}$ \\
\hline $\begin{array}{l}\text { Produção de lenha } \\
\text { (ano 7) }\end{array}$ & 245,00 & 350,00 & 490,00 & $\begin{array}{l}\text { Valor médio igual ao da análise determinista, } \\
\text { valor mínimo } 30 \% \text { menor e valor máximo } 40 \% \\
\text { maior, segundo Elias (1994). }\end{array}$ \\
\hline $\begin{array}{l}\text { Produção de lenha } \\
\text { (ano 14) }\end{array}$ & 217,00 & 310,00 & 434,00 & $\begin{array}{l}\text { Valor médio igual ao da análise determinista, } \\
\text { valor mínimo } 30 \% \text { menor, e valor máximo } 40 \% \\
\text { maior. }\end{array}$ \\
\hline $\begin{array}{l}\text { Produção de lenha } \\
\text { (ano 21) }\end{array}$ & 196,00 & 280,00 & 392,00 & Idem da variável anterior \\
\hline $\begin{array}{l}\text { Custo de } \\
\text { implantação } \\
\text { considerando } \\
\text { aquisição de } \\
\text { mudas (ano 0) }\end{array}$ & 326,11 & $\begin{array}{c}434,81 \\
. \cdot\end{array}$ & 478,29 & $\begin{array}{l}\text { Valor médio igual ao da análise determinista, } \\
\text { valor mínimo } 25 \% \text { menor e máximo } 10 \% \text { maior } \\
\text { que o valor médio, segundo Machado ( } 2000) \text { são } \\
\text { variações percentuais observadas para a cultura } \\
\text { do eucalipto. }\end{array}$ \\
\hline $\begin{array}{l}\text { Custo de } \\
\text { implantação } \\
\text { considerando } \\
\text { doação de mudas } \\
(\text { ano 0) }\end{array}$ & 216,13 & 288,17 & 316,99 & Idem da variável anterior \\
\hline $\begin{array}{l}\text { Custo de } \\
\text { manutenção } \\
\text { (ano 1) }\end{array}$ & 50,21 & 62,76 & 87,86 & $\begin{array}{l}\text { Valor médio igual ao da análise determinista, } \\
\text { valor mínimo } 20 \% \text { menor e valor máximo } 40 \% \\
\text { maior que o valor médio, segundo Machado } \\
(2000)\end{array}$ \\
\hline $\begin{array}{l}\text { Custo de } \\
\text { manutenção } \\
\text { (ano 2) }\end{array}$ & 42,15 & 52,69 & 73,77 & $\begin{array}{l}\text { Valor médio igual ao da análise determinista, } \\
\text { valor mínimo } 20 \% \text { menor e valor máximo } 40 \% \\
\text { maior que o valor médio, segundo Machado } \\
(2000)\end{array}$ \\
\hline $\begin{array}{l}\text { Custos de } \\
\text { manutenção } \\
(\text { anos } 3 \text { a } 6,8 \text { a } \\
13 \text { e } 15 \text { a 20) }\end{array}$ & 34,10 & 42,62 & 68,19 & $\begin{array}{l}\text { Valor médio igual ao da análise determinista, } \\
\text { valor mínimo } 20 \% \text { menor e valor máximo } 60 \% \\
\text { maior que o valor médio. Variações percentuais } \\
\text { observadas para a cultura do eucalipto, segundo } \\
\text { Machado (2000). }\end{array}$ \\
\hline $\begin{array}{l}\text { Custo de } \\
\text { exploração } \\
(7,14 \text { e } 21)\end{array}$ & 163,42 & 204,28 & 326,85 & $\begin{array}{l}\text { Valor médio ao da análise determinista, valor } \\
\text { mínimo } 20 \% \text { menor e valor máximo } 60 \% \text { maior } \\
\text { que o valor médio. Variações percentuais } \\
\text { observadas para a cultura do eucalipto, segundo } \\
\text { Machado (2000). }\end{array}$ \\
\hline Preço da terra & 884,57 & $1.634,78$ & $2.711,27$ & $\begin{array}{l}\text { Valores referentes ao valor da terra para } \\
\text { reflorestamento em novembro de } 1999 \text {, segundo o } \\
\text { IEA. }\end{array}$ \\
\hline
\end{tabular}

Fonte: dados de pesquisa, Machado (2000), Elias (1994) e valores calculados pelo autor 
Quadro H.2 - Definições das variáveis para a análise de risco dos projetos de investimento em reflorestamento com eucalipto no Estado do Paraná.

\begin{tabular}{|c|c|c|c|c|}
\hline \multirow[t]{2}{*}{ Variável } & \multicolumn{3}{|c|}{ Valores } & \multirow[t]{2}{*}{ Definição da variável } \\
\hline & Mínimo & Médio & Máximo & \\
\hline Preço da lenha $\left(\mathrm{m}^{3}\right)$ & 6,00 & 7,50 & 9,00 & $\begin{array}{l}\text { Valor médio igual ao da análise determinista, } \\
\text { valor mínimo } 20 \% \text { menor e valor máximo } 20 \% \\
\text { maior, segundo Dossa et al. }\end{array}$ \\
\hline $\begin{array}{l}\text { Produção de lenha } \\
\text { (ano 7) }\end{array}$ & 180,00 & 225,00 & 280,00 & $\begin{array}{l}\text { Valor médio igual ao da análise determinista, } \\
\text { valor mínimo } 20 \% \text { menor, segundo Dossa et al } \\
(2000) \text { e máximo } 24,44 \% \text { maior, segundo } \\
\text { Rodigheri (1997). }\end{array}$ \\
\hline $\begin{array}{l}\text { Produção de lenha } \\
\text { (ano 14) }\end{array}$ & 172,00 & 215,00 & 267,55 & Idem da variável anterior \\
\hline $\begin{array}{l}\text { Produção de lenha } \\
\text { (ano 21) }\end{array}$ & 153,60 & 192,00 & 238,93 & Idem da variável anterior \\
\hline $\begin{array}{l}\text { Custo de } \\
\text { implantação } \\
\text { considerando } \\
\text { aquisição de mudas } \\
\text { (ano 0) } \\
\end{array}$ & 326,54 & 435,39 & 531,18 & $\begin{array}{l}\text { Valor médio igual ao da análise determinista, } \\
\text { valor mínimo } 25 \% \text { menor de acordo com Machado } \\
(2000) \text {. Valor máximo } 22 \% \text { maior que o valor } \\
\text { médio (baseado em Rodighieri \& Pinto, 1997) }\end{array}$ \\
\hline $\begin{array}{l}\text { Custo de } \\
\text { implantação } \\
\text { considerando } \\
\text { doação de mudas } \\
(\text { ano 0) } \\
\end{array}$ & 230,31 & 307,08 & 374,64 & Idem da variável anterior \\
\hline $\begin{array}{l}\text { Custo de } \\
\text { manutenção (ano 1) }\end{array}$ & 65,72 & 82,15 & 115,01 & $\begin{array}{l}\text { Valor médio igual ao da análise determinista, } \\
\text { valor mínimo } 20 \% \text { menor e valor máximo } 40 \% \\
\text { maior que o valor médio,segundo Machado (2000) }\end{array}$ \\
\hline $\begin{array}{l}\text { Custos de } \\
\text { manutenção } \\
(\text { anos } 2 \text { a } 6,9 \text { a } 13 \\
\text { e } 16 \text { a 20) }\end{array}$ & 14,46 & $\begin{array}{l}18,08 \\
\cdot .\end{array}$ & 28,93 & $\begin{array}{l}\text { Valor médio igual ao da análise determinista, } \\
\text { valor mínimo } 20 \% \text { menor e valor máximo } 60 \% \\
\text { maior que o valor médio. Variações percentuais } \\
\text { observadas para a cultura do eucalipto, segundo } \\
\text { Machado (2000). }\end{array}$ \\
\hline $\begin{array}{l}\text { Custo de } \\
\text { exploração } \\
(7 \text { e } 14)\end{array}$ & 172,61 & 215,76 & 345,22 & $\begin{array}{l}\text { Valor médio igual ao da análise determinista, } \\
\text { valor mínimo } 20 \% \text { menor e valor máximo } 60 \% \\
\text { maior que o valor médio. Variações percentuais } \\
\text { observadas para a cultura do eucalipto, segundo } \\
\text { Machado (2000). }\end{array}$ \\
\hline $\begin{array}{l}\text { Custo de } \\
\text { exploração } \\
\text { (ano 21) }\end{array}$ & 130,18 & 162,72 & 260,35 & $\begin{array}{l}\text { Valor médio igual ao da análise determinista, } \\
\text { valor mínimo } 20 \% \text { menor e valor máximo } 60 \% \\
\text { maior que o valor médio. Variações percentuais } \\
\text { observadas para a cultura do eucalipto, segundo } \\
\text { Machado (2000). }\end{array}$ \\
\hline \begin{tabular}{|l|} 
Custo de \\
regeneração \\
(ano 8 e 15)
\end{tabular} & 78,91 & 98,64 & 157,83 & Idem variável anterior. \\
\hline Preço da terra & 465,83 & $1.307,53$ & $2.122,56$ & $\begin{array}{l}\text { Valores referentes ao valor da terra mista no } \\
\text { Paraná em novembro de } 1999 \text {, segundo o } \\
\text { DERAL/SEAB. }\end{array}$ \\
\hline
\end{tabular}

Fonte: Dossa et al. (2000), Rodighieri \& Pinto (1997), Machado (2000) e valores calculados pelo autor 
Quadro H.3 - Definições das variáveis para a análise de risco dos projetos de investimento em reflorestamento com eucalipto no Estado de Minas Gerais.

\begin{tabular}{|c|c|c|c|c|}
\hline \multirow[t]{2}{*}{ Variável } & \multicolumn{3}{|c|}{ Valores } & \multirow[t]{2}{*}{ Definição da variável } \\
\hline & Mínimo & Médio & Máximo & \\
\hline $\begin{array}{l}\text { Preço da lenha de } \\
\text { eucalipto no mercado (st) }\end{array}$ & 6,00 & 10,00 & 11,00 & $\begin{array}{l}\text { Valor médio igual ao da análise determinista, valor } \\
\text { mínimo e máximo praticados na região do Vale do Rio } \\
\text { Doce-MG. }\end{array}$ \\
\hline $\begin{array}{l}\text { Preço da madeira de } \\
\text { eucalipto pago pela } \\
\text { empresa fomentadora (st) }\end{array}$ & 13,50 & 14,25 & 15,00 & $\begin{array}{l}\text { Valor médio igual ao da análise determinista, valor } \\
\text { mínimo e máximo praticado pela empresa fomentadora } \\
\text { na região do Vale do Rio Doce. }\end{array}$ \\
\hline $\begin{array}{l}\text { Produção de madeira } \\
\text { (ano 7) }\end{array}$ & 262,50 & 375,00 & 609,38 & Idem da variável anterior \\
\hline $\begin{array}{l}\text { Produção de madeira } \\
\text { (ano 14) }\end{array}$ & 238,00 & 340,00 & 552,50 & Idem da variável anterior \\
\hline $\begin{array}{l}\text { Produção da lenha } \\
\text { (ano 21) }\end{array}$ & 210,00 & 300,00 & 487,50 & Idem da variável anterior \\
\hline $\begin{array}{l}\text { Custo de implantação } \\
\text { (ano 0) }\end{array}$ & 253,05 & 337,40 & 371,14 & $\begin{array}{l}\text { Valor médio igual ao da análise determinista, valor } \\
\text { mínimo } 25 \% \text { menor e valor máximo } 10 \% \text { maior que o } \\
\text { valor médio. Variações percentuais observadas para a } \\
\text { cultura do eucalipto segundo Machado }(2000) \text {. }\end{array}$ \\
\hline $\begin{array}{l}\text { Custo de manutenção } \\
\text { (ano 1) }\end{array}$ & 117,48 & 146,85 & 205,59 & $\begin{array}{l}\text { Valor médio igual ao da análise determinista, valor } \\
\text { mínimo } 20 \% \text { menor e valor máximo } 40 \% \text { maior que o } \\
\text { valor médio. Variações percentuais observadas para a } \\
\text { cultura do eucalipto, segundo Machado (2000). }\end{array}$ \\
\hline $\begin{array}{l}\text { Custo de manutenção } \\
\text { (ano 2) }\end{array}$ & 35,28 & 44,10 & 61,74 & Idem da variável anterior \\
\hline $\begin{array}{l}\text { Custo de manutenção } \\
\text { (ano 3) }\end{array}$ & 11,52 & 14,40 & 20,16 & Idem da variável anterior \\
\hline $\begin{array}{l}\text { Custos de manutenção } \\
\text { (anos } 4 \text { a } 7,11 \text { a } 14 \text { e } 18 \\
\text { a 21) }\end{array}$ & 70,20 & 87,75 & 140,40 & $\begin{array}{l}\text { Valor médio igual ao da análise determinista, valor } \\
\text { mínimo } 20 \% \text { menor e valor máximo } 60 \% \text { maior que o } \\
\text { valor médio. Variações percentuais observadas para a } \\
\text { cultura do eucalipto, segundo Machado }(2000) \text {. }\end{array}$ \\
\hline $\begin{array}{l}\text { Custo de manutenção } \\
\text { (anos } 9 \text { e 16) }\end{array}$ & 80,28 & 100,35 & 160,56 & Idem da variável anterior \\
\hline $\begin{array}{l}\text { Custo de regeneração } \\
\text { (ano } 8 \text { e 15) }\end{array}$ & 308,00 & 385,00 & 616,00 & Idem da variável anterior \\
\hline $\begin{array}{l}\text { Custo de manutenção } \\
\text { (ano } 10 \text { e 17) }\end{array}$ & 26,56 & 33,20 & 53,12 & Idem da variável anterior \\
\hline $\begin{array}{l}\text { Custo de exploração } \\
\text { (ano 7) }\end{array}$ & $1.340,00$ & $1.675,00$ & $2.680,00$ & Idem da variável anterior \\
\hline $\begin{array}{l}\text { Custo de exploração } \\
\text { (ano 14) }\end{array}$ & $1.088,00$ & $\cdot 1.360,00$ & $2.176,00$ & $\begin{array}{l}\text { Valor médio igual ao da análise determinista. Valor } \\
\text { mínimo } 20 \% \text { menor. Valor máximo } 60 \% \text { maior que o } \\
\text { valor médio, segundo Machado }(2000) \text {. }\end{array}$ \\
\hline $\begin{array}{l}\text { Custo de exploração } \\
\text { (ano 21) }\end{array}$ & 960,00 & $1.200,00$ & $1.920,00$ & Idem da variável anterior \\
\hline Preço da terra & 300,00 & 400,00 & 500,00 & $\begin{array}{l}\text { Valores referentes a terra nua em novembro de } 1999, \\
\text { segundo IEF/MG }\end{array}$ \\
\hline
\end{tabular}

Fonte: Machado (2000), dados de pesquisa e valores calculados pelo autor 